\title{
Iridium-catalyzed Csp3-H Activation for Mild and Selective Hydrogen Isotope Exchange
}

\author{
William J. Kerr, ${ }^{*},{ }^{\dagger}$ Richard J. Mudd, ${ }^{\dagger}$ Marc Reid, ${ }^{\dagger}$ Jens Atzrodt, ${ }^{\ddagger}$ and Volker Derdau ${ }^{\ddagger}$ \\ Department of Pure \& Applied Chemistry, WestCHEM, University of Strathclyde, Glasgow G1 1XL, Scotland, UK. \\ ¥Integrated Drug Discovery, Isotope Chemistry, Sanofi-Aventis Deutschland GmbH, Industriepark Hoechst, Frankfurt, Ger- \\ many.
}

\begin{abstract}
The increasing demand for isotopically labeled compounds has provided appreciable impetus for the development of improved methods for the late stage introduction of isotopes of hydrogen (deuterium or tritium). Moreover, $\mathrm{sp}^{3}$-rich molecules are becoming increasingly common in the exploration of chemical space for drug design. Herein, we report an efficient iridium(I) catalysed $\mathrm{C}-\mathrm{H}$ activation method for the hydrogen isotope exchange of $\mathrm{sp}^{3} \mathrm{C}-\mathrm{H}$ bonds. A wide range of substrates have been labeled, including active pharmaceutical ingredients, delivering excellent levels of isotope incorporation and predictable regiocontrol, with low catalyst loadings, in short reaction times, and under mild reaction conditions.
\end{abstract}

KEYWORDS: C-H activation, iridium, isotopes, homogeneous catalysis, heterocycles.

Transition metal-mediated $\mathrm{C}-\mathrm{H}$ activation has received significant attention in recent years, and continues to produce prominent new methods for complex chemical synthesis. ${ }^{1}$ Despite such widespread use, the majority of applications are aimed towards $\mathrm{sp}^{2} \mathrm{C}-\mathrm{H}$ bonds, which are intrinsically more readily activated, with considerably fewer applications targeting the activation of $\mathrm{sp}^{3} \mathrm{C}-\mathrm{H}$ bonds. Furthermore, iridiumcatalyzed $\mathrm{sp}^{3} \mathrm{C}-\mathrm{H}$ activation processes are rare, ${ }^{10,2,3}$ with reported catalytic applications focused upon alkylation, ${ }^{3 a, e}$ alkenylation, ${ }^{3 \mathrm{~b}, \mathrm{c}}$ oxidation, ${ }^{3 \mathrm{~d}}$ and amidation. ${ }^{3 \mathrm{f}}$ However, in the majority of these cases, high temperatures and extended reaction times are required. In relation to this, hydrogen isotope exchange (HIE) provides a fundamental basis for the investigation of new $\mathrm{C}-\mathrm{H}$ activation processes, as well as providing a means of generating valuable, specifically deuterated molecular units for mechanistic studies. ${ }^{4}$ Additionally, such flexible and direct methods of producing isotopically-labeled compounds are of appreciable importance for the pharmaceutical industry, especially within absorption, distribution metabolism, excretion, toxicity, and stability (ADMETS) studies of active pharmaceutical ingredients (APIs). ${ }^{4 a, 5}$

Inspired by the structural architecture of Crabtree's catalyst, ${ }^{6,7}$ we developed a series of iridium(I) complexes of the type $\left[(\mathrm{COD}) \operatorname{Ir}(\mathrm{IMes})\left(\mathrm{PR}_{3}\right)\right] \mathrm{X}$, capable of delivering heavy isotopes of hydrogen (deuterium, $\mathrm{D}$, and tritium, $\mathrm{T}$ ) to aromatic and olefinic compounds via a directed $\mathrm{sp}^{2} \mathrm{C}-\mathrm{H}$ activation process, under mild conditions and short reaction times with a plethora of directing groups (Scheme 1 , (a)).$^{8-10}$ Complementary to the directing group approach, the growing interest in this area of research is further exemplified by recent reports detailing iron, ${ }^{11 \mathrm{a}}$ cobalt, ${ }^{11 \mathrm{~b}}$ and photoredox ${ }^{12}$ catalysis methods for the introduction of an isotopic label at sterically unencumbered aryl $\left(\mathrm{sp}^{2}\right)$ and oxidatively active alkyl $\left(\mathrm{sp}^{3}\right)$ positions, respectively (Scheme 1 (b) and (c)). Accordingly, a general method for the directed introduction of a hydrogen isotope at $\mathrm{sp}^{3}$ centers would deliver this previously unmet requirement, whilst also having the potential to provide further insight into $\mathrm{sp}^{3} \mathrm{C}-\mathrm{H}$ activation processes. Following the recent

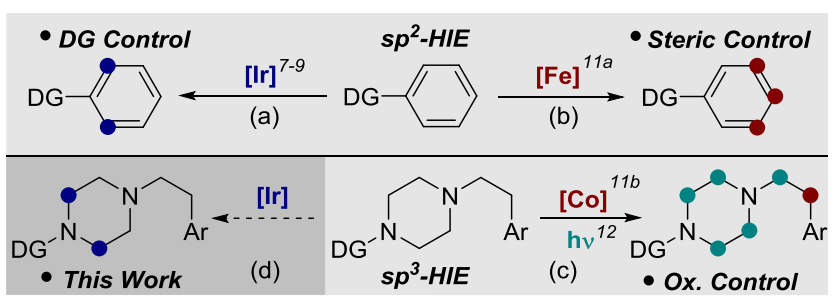

Scheme 1. Complementary approaches to hydrogen isotope exchange.

disclosure of methylene labelling in a range of amides, ${ }^{3 \mathrm{~g}}$ we now report the selective $\mathrm{C}-\mathrm{H}$ activation and hydrogen isotope exchange on $\mathrm{sp}^{3}$ centers utilizing our developed iridium(I) $\mathrm{NHC} /$ phosphine complexes as directed by a range of pharmaceutically-relevant heterocyclic units, in turn expanding the utility of these catalysts and providing expedient access to a new range of important labeled chemical entities (Scheme 1 (d)).

Our studies commenced with the application of a range of developed iridium(I) complexes 1a-1e, as well as Crabtree's catalyst 1 f and related $\mathrm{BAr}^{\mathrm{F}}$ analogue $\mathbf{1 g}$, in a HIE reaction using commercially available 4-(pyridine-2-yl)morpholine $\mathbf{2}$, as a typical, drug-like heterocyclic motif. ${ }^{13}$ Pleasingly, when applying the NHC/phosphine complex 1a, we observed selective D-incorporation at the four positions $\alpha$ to the morpholine nitrogen only (Table 1, Entry 1). This incorporation was improved to deliver excellent levels of labeling by utilizing complex 1b bearing the less coordinating $\mathrm{BAr}^{\mathrm{F}}$ counterion (Table 1, Entry 2). ${ }^{8 \mathrm{e}, \mathrm{h}, \mathrm{j}}$ Further manipulation of the iridium complex by variation of the phosphine ligand resulted in a small decrease in D-incorporation (Table 1, Entries 3 and 4). Also, despite its reported use in $\mathrm{sp}^{2} \mathrm{HIE},{ }^{9 \mathrm{a}-\mathrm{c}}$ the neutral complex $1 \mathrm{e}$ proved to be inactive for $\mathrm{sp}^{3}$ exchange under these conditions (Table 1, Entry 5). Similarly, the smaller ligand sphere of Crabtree catalysts $\mathbf{1 f}$ and $\mathbf{1 g}$ delivered only low levels of Dincorporation (Table 1, Entries 6 and 7). With catalyst 1b selected for further exploration of reaction parameters, we 
Table 1. Screening of Catalysts 1a-g. ${ }^{a}$

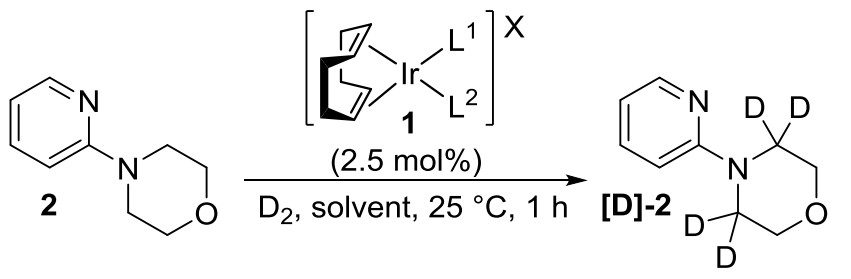

\begin{tabular}{|c|c|c|c|c|}
\hline Entry & $\mathrm{L}^{1}, \mathrm{~L}^{2}, \mathrm{X}^{b}$ & Catalyst & Solvent & $\% \mathrm{D}^{c}$ \\
\hline 1 & IMes, $\mathrm{PPh}_{3}, \mathrm{PF}_{6}$ & $1 \mathbf{a}$ & DCM & 79 \\
\hline 2 & IMes, $\mathrm{PPh}_{3}, \mathrm{BAr}^{\mathrm{F}}$ & $1 b$ & DCM & 90 \\
\hline 3 & IMes, $\mathrm{PBn}_{3}, \mathrm{BAr}^{\mathrm{F}}$ & 1c & DCM & 85 \\
\hline 4 & IMes, $\mathrm{PMePh}_{2}, \mathrm{BAr}^{\mathrm{F}}$ & 1d & DCM & 78 \\
\hline 5 & IMes, $\mathrm{Cl}$ & $1 \mathrm{e}$ & DCM & 0 \\
\hline 6 & $\mathrm{Py}, \mathrm{PCy}_{3}, \mathrm{PF}_{6}$ & 1f & DCM & 24 \\
\hline 7 & $\mathrm{Py}, \mathrm{PCy}_{3}, \mathrm{BAr}^{\mathrm{F}}$ & $1 g$ & DCM & 26 \\
\hline 8 & IMes, $\mathrm{PPh}_{3}, \mathrm{BAr}^{\mathrm{F}}$ & $1 \mathrm{~b}$ & tAmylOH & 76 \\
\hline 9 & IMes, $\mathrm{PPh}_{3}, \mathrm{BAr}^{\mathrm{F}}$ & $1 b$ & MTBE & 87 \\
\hline 10 & IMes, $\mathrm{PPh}_{3}, \mathrm{BAr}^{\mathrm{F}}$ & $1 b$ & tBuOAc & 86 \\
\hline
\end{tabular}

${ }^{a}$ Each entry displayed is the average of two reaction runs. Conditions: $2(0.086 \mathrm{mmol})$, solvent $(1 \mathrm{~mL})$, catalyst $(0.00215 \mathrm{mmol})$. ${ }^{b} \mathrm{BAr}{ }^{\mathrm{F}}=$ tetrakis(3,5-triflouromethylphenyl)borate. ${ }^{c}$ Percentage deuterium incorporation calculated from LCMS, with the position confirmed by ${ }^{1} \mathrm{H}$ NMR spectroscopy.

examined the flexibility of the reaction medium, understanding that many APIs are not soluble in DCM. Encouragingly, the reaction could be performed in a range of alcohol, ether and ester-derived solvents, with only a slight reduction in Dincorporation when applying $t$-amyl alcohol, MTBE or $t$ BuOAc (Table 1, Entries 8-10) (see ESI for full range of solvents tested).

Subsequent investigations examined the reaction conditions thoroughly, applying a design of experiments (DoE) approach $^{14}$ to optimization of the labelling process using catalyst $\mathbf{1 b}$ with substrate $\mathbf{2}$ in DCM. To this end, we applied a three-factor, two-level, full factorial design investigating the catalyst loading, reaction time, and reaction volume (see ESI for full details). This study clearly demonstrated that catalyst loading, and to a lesser extent reaction time, influenced the Dincorporation. Additionally, increasing the reaction volume was found to have a small positive effect upon the result, indicating that substrate complexation and subsequent product decomplexation influences the catalyst turnover, ${ }^{15}$ in accordance with our mechanistic observations in $\mathrm{sp}^{2}$-HIE systems. ${ }^{8 \mathrm{~d}}$

Following a detailed examination of the results garnered from the DoE, an optimized protocol using notably low catalyst loadings for $\mathrm{sp}^{3} \mathrm{C}-\mathrm{H}$ activation and HIE was developed (Scheme 2, Conditions A: 1b (1 mol\%), $\mathrm{D}_{2}, \mathrm{DCM}(1 \mathrm{~mL}), 1$ h), and applied to a range of saturated heterocyclic substrates (Scheme 2a). Initial studies focused on the influence that other $\mathrm{N}$-heterocycles had when acting as a directing group for the C$\mathrm{H}$ activation. Beyond previously applied pyridine substrate $\mathbf{2}$, exchange was facilitated well with pyrimidine, quinoline, and isoquinoline directing groups, delivering $\geq 94 \%$ Dincorporation across the four specific $\mathrm{C}-\mathrm{H}$ labeling sites of the morpholine ring in 3-5. In addition to the $\mathrm{sp}^{3}$-exchange, Dincorporation was observed at positions ortho to the nitro and ester directing groups in $\mathbf{6}$ and 7. Pleasingly, the $\mathrm{sp}^{3}$-exchange was preferred in the case of ester 7, presumably because the greater Lewis basicity of the $N$-heterocyclic directing group favors coordination to the catalyst and subsequent $\mathrm{sp}^{3}$ exchange. This hypothesis is further supported by the example of $\mathrm{N}$-acetyl morpholine $\mathbf{8}$, where, under the optimized conditions, no D-incorporation was observed, and heating the reaction $\left(5 \mathrm{~mol} \% \mathbf{1 b}, \mathrm{D}_{2}, \mathrm{MTBE}, 50^{\circ} \mathrm{C}, 3 \mathrm{~h}\right)$ resulted in only minimal incorporation.

Similar trends were observed within piperidine-derived substrates 9 and 11-15, with consistently high D-incorporation being obtained (Scheme 2b). The level of labeling with thiazole 10 remained high despite the anticipated increase in ring strain present in the cyclometallated intermediate with this 5membered directing heterocycle. Notably, compound $\mathbf{1 4}$ is insoluble in DCM, but the broad solvent compatibility of catalyst $\mathbf{1 b}$ allowed this substrate to be labeled in 2-MeTHF, resulting in good levels of D-incorporation. In addition, where the axial and equatorial protons can be distinguished by ${ }^{1} \mathrm{H}$ NMR spectroscopy (11-15), the equatorial exchange is favored slightly, plausibly indicating a stronger agostic interaction between the catalyst and the equatorial $\mathrm{C}-\mathrm{H}$ bond.

Following successful application to a range of morpholines and piperidines, we applied optimized Conditions A to piperazines (Scheme 2c), with initial results yielding lowered levels of D-incorporation (Conditions A, 16-20). However, we observed that when the free amine was converted to an $N$-methyl unit, high incorporations were re-established (19 vs $\mathbf{2 1}$, and $\mathbf{2 0}$ vs 22). Therefore, the decreased activity of these compounds clearly relates to an interaction between the free amine and catalyst, generating a different species from the active catalyst, as has been observed by ${ }^{31} \mathrm{P}$ NMR spectroscopy (see ESI for full details). ${ }^{16}$ However, since the exchange process still continues, albeit to a lesser degree, the unreactive complex is presumed to form reversibly.

With this information in hand, we applied a second DoE phase, this time utilizing 1-(pyridin-2-yl)piperazine $\mathbf{1 6}$ as a reference substrate, to develop conditions that would facilitate exchange without protection of the piperazine. This DoE approach returned a similar dependency upon catalyst loading, reaction time, and reaction volume (see ESI for full details), and provided a second protocol (Conditions B: $5 \mathrm{~mol} \% \mathbf{1 b}, \mathrm{D}_{2}$, DCM (1 mL), $3 \mathrm{~h})$. Pleasingly, under the newly developed conditions, high levels of D-incorporation were observed and, crucially, without protection of piperazines 16-20.

Keen to develop a general protocol for the labeling of saturated $N$-heterocycles, we next considered the effect of changing the size of the ring being labeled (Scheme 2d). Under Conditions A, HIE occurs to deliver a moderate Dincorporation within both azepane 23 and pyrrolidine $\mathbf{2 4}$, but with no incorporation in azetidine $\mathbf{2 5}$. In contrast, by utilizing Conditions B, high levels of D-incorporation can be achieved 


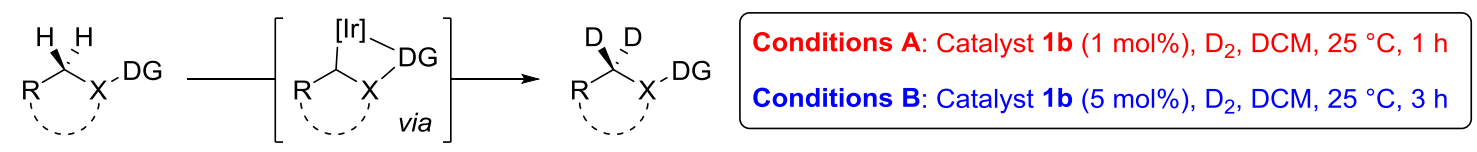

a Morpholines<smiles>BrC1COCCN1c1ccccn1</smiles><smiles>Brc1cnc(N2CCOC[C@H]2c2ccccc2)nc1</smiles><smiles></smiles><smiles>C[C@@H]1COCCN1c1nccc2ccccc12</smiles>

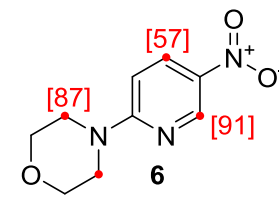<smiles>[3H]C(F)=CC=N</smiles>

4

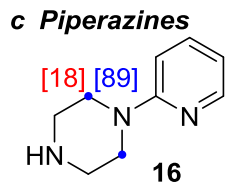

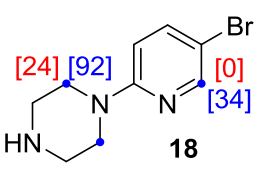

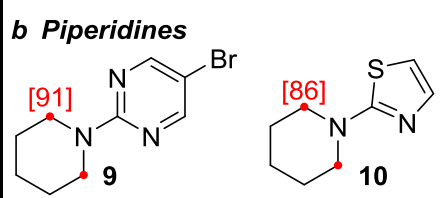
$\mathrm{ax}=[83]$ eq $=[84]$<smiles>[N]CN1[CH]CC(O)CC1</smiles>

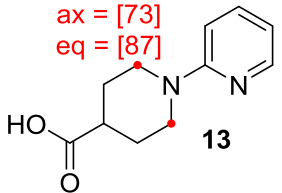
8<smiles>CC(C)N1CCNCC1c1ncc(Br)cn1</smiles>

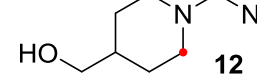

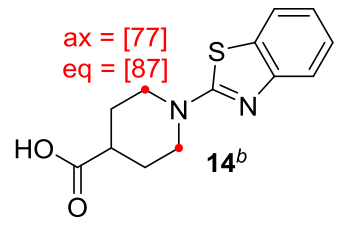<smiles>[13CH2][C@@H]1CC(C(=O)O)CCN1c1ccc(C(F)(F)F)cn1</smiles>

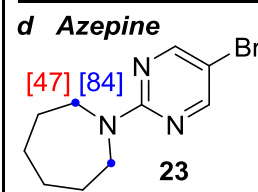

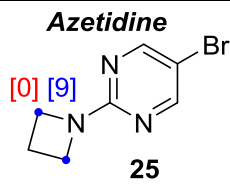

\section{e Aliphatics}

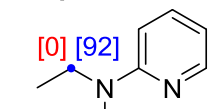

[0] [92] 26

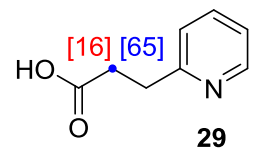<smiles>[Mg][Mg]Nc1ccccn1</smiles>

27

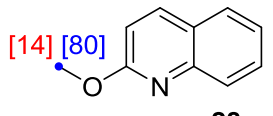

28<smiles>CCOC(=O)Cc1ccccn1</smiles>

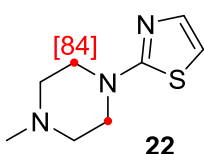

22<smiles>CN1C[C@@H]2c3ccccc3Cc3cccnc3N2[C@H](c2ccccc2)C1</smiles>

Mirtazapine 31<smiles></smiles>

Azaperone 32<smiles>Cn1c(=O)c2c(ncn2C)n([13CH2])c1=O</smiles>

Caffeine 33

Scheme 2. Hydrogen isotope exchange on saturated $\boldsymbol{N}$-heterocycles. Conditions A or B with substrate $(0.086 \mathrm{mmol})$ in DCM (1 $\mathrm{mL})$. Percentage deuterium incorporation at each site calculated by ${ }^{1} \mathrm{H}$ NMR spectroscopy. ${ }^{a} 1 \mathrm{~b}(5 \mathrm{~mol} \%), \mathrm{MTBE}, 50{ }^{\circ} \mathrm{C}, 3 \mathrm{~h}$. ${ }^{b}$ Reaction performed in 2-MeTHF instead of DCM.

in $\mathbf{2 3}$ and $\mathbf{2 4}$, and a small level of labelling is evolved in $\mathbf{2 5}$. This series indicates that the heterocycle ring size can affect the efficiency of the HIE process, presumably by influencing the strain in the metallacyclic intermediate following $\mathrm{C}-\mathrm{H}$ activation.

Following our success with saturated heterocycles, we next turned our attention to non-cyclic substrate components (Scheme 2e). Initial reactions with $N$-ethyl- $N$-methylpyridin-2amine 26 and $N$-methylpyridin-2-amine 27 delivered no incorporation, and $O$-methylquinoline $\mathbf{2 8}$ showed only low levels of exchange on the $O$-methyl group. Accordingly, we turned to our second protocol, Conditions B, which gave high levels of incorporation at both the methyl- and methylene positions of 26, and the $O$-methyl of $\mathbf{2 8}$. In contrast, substrate 27 underwent only moderate levels of exchange, perhaps due to the unprotected secondary amine. Next, we examined several substrates with $\mathrm{sp}^{3} \mathrm{C}-\mathrm{H}$ bonds which do not possess an $\alpha$ heteroatom, but which instead are adjacent to acid and ester functionalities (29-30). Under Conditions B, somewhat more moderate levels of D-incorporation were observed at the site arising from $\mathrm{C}-\mathrm{H}$ activation via a 5-membered metallocycle.
Having established the utility of our labelling process on a broad range of heterocycles and acyclic substrates, we applied the developed method to several commercially available drug compounds (Scheme 2f). The anti-depressant Mirtazapine 31 does not contain any $\mathrm{sp}^{2}$ centers which could be labelled via directed HIE, however its pyridine nitrogen could direct $\mathrm{sp}^{3}$ labelling. Applying conditions A, we were pleased to observe a high D-incorporation of $94 \%$ on the piperazine ring. Similarly, a high incorporation was obtained on the piperazine ring of the tranquilizer Azaperone 32, and notably with excellent selectivity versus the ortho $\mathrm{sp}^{2}$-exchange directed by the ketone. Finally, application of conditions $\mathrm{B}$ to the stimulant Caffeine 33 resulted in a highly selective labelling at the 7-methyl position, directed by the imidazole nitrogen.

We next looked to investigate the mechanism through which the exchange occurs. Firstly, we confirmed a homogeneous catalysis process by continuation of the reaction in the presence of metallic mercury. ${ }^{17}$ Secondly, a mechanism involving more than one molecule of catalyst during the rate determining step was discounted, by observing a first order rate dependence with respect to catalyst (see ESI for full details). Finally, by measuring the rate of reaction for both the 
installation and removal of deuterium (Scheme 3), a kinetic isotope effect of 3.22 was established, which indicates an iridium-mediated $\mathrm{C}-\mathrm{H}$ activation as the rate determining step. ${ }^{18}$

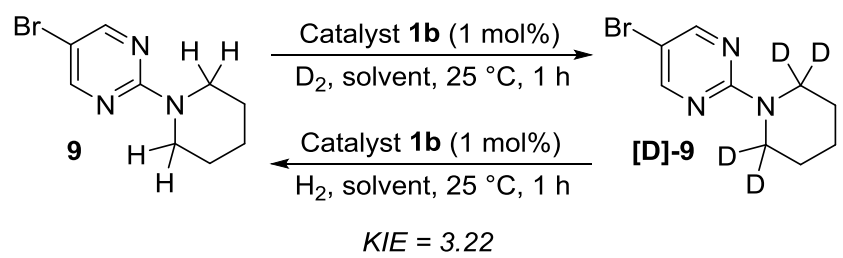

Scheme 3. Kinetic isotope studies.

Taken together, these pieces of experimental evidence are consistent with our mechanistic observations in the $\mathrm{sp}^{2} \mathrm{C}-\mathrm{H}$ activation and hydrogen isotope exchange catalyzed by complexes of type 1a-e. ${ }^{8 \mathrm{~d}, 9 \mathrm{~b}}$ As a result, it is plausible to propose a similar mechanistic pathway (Scheme 4), beginning with activation of the pre-catalyst $\mathbf{1}$ to the key iridium(III) dihydride intermediate I. Displacement of solvent and coordination of substrate, including the key agostic interaction with the exchange site, delivers II. Subsequent C-H insertion results in metallacycle III, followed by deuterium-hydrogen fluxionality affording complex IV. This intermediate can then undergo C$\mathrm{D}$ bond formation to generate $\mathbf{V}$, prior to product decomplexation and regeneration of active intermediate $\mathbf{I}$.

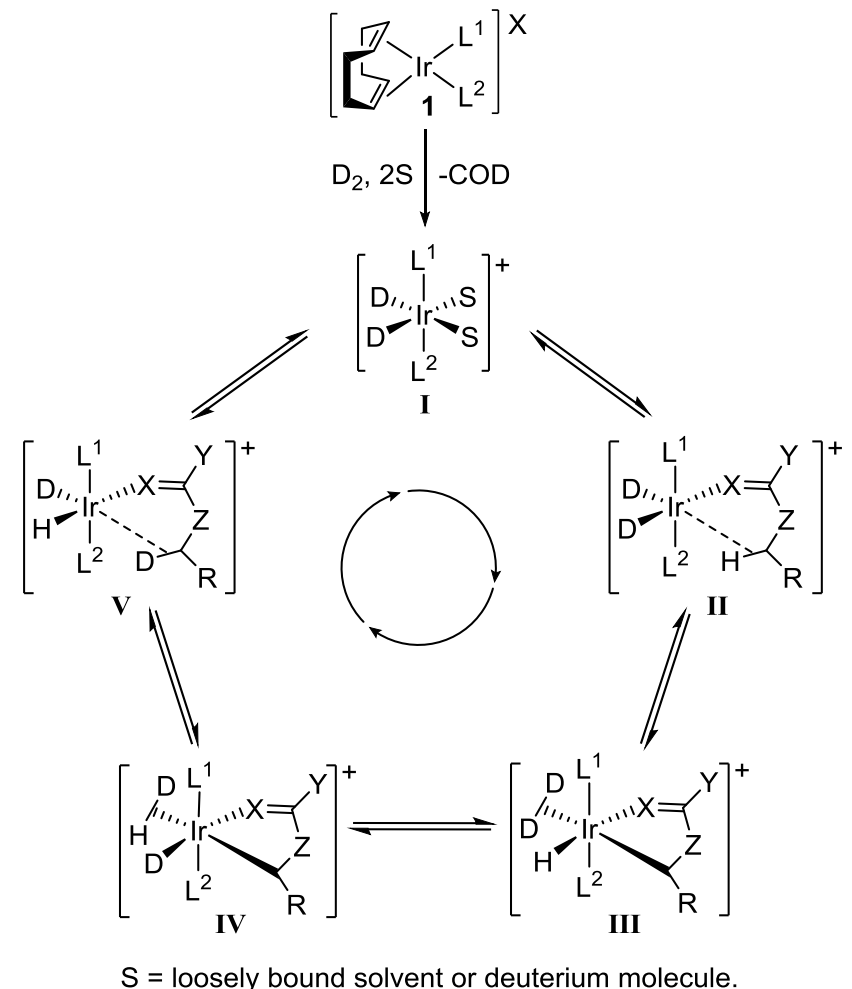

Scheme 4. Proposed mechanism for $\mathrm{sp}^{3}$-hydrogen isotope exchange.

To conclude, we have developed new protocols for directed and selective hydrogen isotope exchange at $\mathrm{sp}^{3} \mathrm{C}-\mathrm{H}$ centers, resulting in high levels of D-incorporation with low catalyst loadings and under mild reaction conditions. Exploration of a broad variety of substrates has shown the protocols to be efficient and reliable across a wide range of saturated het- erocycles and aliphatic units. Application of the labelling conditions to commercial drug compounds also results in high levels of exchange selective for $\mathrm{sp}^{3}$ positions. Beyond the substrate scope, we have investigated the mechanism of this process, providing evidence for a pathway proceeding via $\mathrm{sp}^{3}-\mathrm{C}$ $\mathrm{H}$ activation as the rate determining step. Further work is underway in our laboratory to further explore the $\mathrm{sp}^{3}$-HIE of complex molecules and these studies will be reported in due course.

\section{AUTHOR INFORMATION}

\section{Corresponding Author}

*Email: w.kerr@strath.ac.uk

\section{Notes}

The authors declare no competing financial interest.

\section{ASSOCIATED CONTENT}

Details of experimental procedures and computational methods can be found in the Electronic Supporting Information (ESI). This material is available free of charge via the Internet at http://pubs.acs.org.

\section{ACKNOWLEDGMENTS}

Studentship (R.J.M.) support from the University of Strathclyde is gratefully acknowledged. W.J.K. and M.R. would like to thank the Carnegie Trust for funding. Mass spectrometry data were acquired at the EPSRC UK National Mass Spectrometry Facility at Swansea University.

\section{REFERENCES}

(1) (a) Ackermann, L. Carboxylate-Assisted Transition-MetalCatalyzed $\mathrm{C}-\mathrm{H}$ Bond Functionalizations: Mechanism and Scope. Chem. Rev. 2011, 111, 1315-1345. (b) Wencel-Delord, J.; Dröge, T.; Liu, F.; Glorius, F. Towards Mild Metal-Catalyzed C-H Bond Activation. Chem. Soc. Rev. 2011, 40, 4740-4761. (c) Cho, S. H.; Kim, J. Y.; Kwak, J.; Chang, S. Recent Advances in the Transition MetalCatalyzed Twofold Oxidative C-H Bond Activation Strategy for C-C and C-N Bond Formation. Chem. Soc. Rev. 2011, 40, 5068-5083. (d) Yeung, C. S.; Dong, V. M. Catalytic Dehydrogenative CrossCoupling: Forming Carbon-Carbon Bonds by Oxidizing Two Carbon-Hydrogen Bonds. Chem. Rev. 2011, 111, 1215-1292. (e) McMurray, L.; O'Hara, F.; Gaunt, M. J. Recent Developments in Natural Product Synthesis using Metal-Catalysed C-H Bond Functionalisation. Chem. Soc. Rev. 2011, 40, 1885-1898. (f) Engle, K. M.; Mei, T.-S.; Wasa, M.; Yu, J.-Q. Weak Coordination as a Powerful Means for Developing Broadly Useful C-H Functionalization Reactions. Acc. Chem. Res. 2012, 45, 788-802. (g) Song, G.; Wang, F.; Li, X. C-C, C-O and $\mathrm{C}-\mathrm{N}$ Bond Formation via Rhodium(III)-Catalyzed Oxidative C-H Activation. Chem. Soc. Rev. 2012, 41, 3651-3678. (h) Kuhl, N.; Hopkinson, M. N.; Wencel-Delord, J.; Glorius, F. Beyond Directing Groups: Transition-Metal-Catalyzed C-H Activation of Simple Arenes. Angew. Chem. Int. Ed. 2012, 51, 10236-10254. (i) Neufeldt, S. R.; Sanford, M. S. Controlling Site Selectivity in Palladium-Catalyzed $\mathrm{C}-\mathrm{H}$ Bond Functionalization. Acc. Chem. Res. 2012, 45, 936-946. (j) Yamaguchi, J.; Yamaguchi, A. D.; Itami, K. C-H Bond Functionalization: Emerging Synthetic Tools for Natural Products and Pharmaceuticals. Angew. Chem. Int. Ed. 2012, 51, 89609009. (k) Shi, G.; Zhang, Y. Carboxylate-Directed C-H Functionalization. Adv. Synth. Catal. 2014, 356, 1419-1442. (1) Kuhl, N.; Schröder, N.; Glorius, F. Formal $\mathrm{S}_{\mathrm{N}}$-Type Reactions in Rhodium(III)-Catalyzed C-H Bond Activation. Adv. Synth. Catal. 2014, 356, 1443-1460. (m) De Sarkar, S.; Liu, W.; Kozhushkov, S. I.; Ackermann, L. Weakly Coordinating Directing Groups for Ruthenium(II)-Catalyzed C-H Activation. Adv. Synth. Catal. 2014, 356, 1461-1479. (n) Ackermann, L. Carboxylate-Assisted Ruthenium-Catalyzed Alkyne Annulations 
by $\mathrm{C}-\mathrm{H} / \mathrm{Het}-\mathrm{H}$ Bond Functionalizations. Acc. Chem. Res. 2014, 47 , 281-295. (o) Ros, A.; Fernández, R.; Lassaletta, J. M. Functional Group Directed C-H Borylation. Chem. Soc. Rev. 2014, 43, 32293243. (p) Girard, S. A.; Knauber, T.; Li, C.-J. The CrossDehydrogenative Coupling of $\mathrm{C}_{\mathrm{sp} 3}-\mathrm{H}$ Bonds: A Versatile Strategy for C-C Bond Formations. Angew. Chem. Int. Ed. 2014, 53, 74-100. (q) Yang, L.; Huang, H. Transition-Metal-Catalyzed Direct Addition of Unactivated $\mathrm{C}-\mathrm{H}$ Bonds to Polar Unsaturated Bonds. Chem. Rev. 2015, 115, 3468-3517. (r) Xue, X.-S.; Ji, P.; Zhou, B.; Cheng, J.-P. The Essential Role of Bond Energetics in C-H Activation/Functionalization. Chem. Rev. 2017, 117, 8622-8648. (s) Newton, C. G.; Wang, S.-G.; Oliveira, C. C.; Cramer N. Catalytic Enantioselective Transformations Involving $\mathrm{C}-\mathrm{H}$ Bond Cleavage by Transition-Metal Complexes. Chem. Rev. 2017, 117, 8908-8976. (t) Qin, Y.; Zhu, L.; Luo, S. Organocatalysis in Inert $\mathrm{C}-\mathrm{H}$ Bond Functionalization. Chem. Rev. 2017, 117, 9433-9520.

(2) For selected stoichiometric examples of iridium-catalyzed $\mathrm{sp}^{3}-\mathrm{C}-\mathrm{H}$ activation, see: (a) Janowicz, A. H.; Bergman, R. G. CarbonHydrogen Activation in Completely Saturated Hydrocarbons: Direct Observation of M $+\mathrm{R}-\mathrm{H} \rightarrow \mathrm{M}(\mathrm{R})(\mathrm{H})$. J. Am. Chem. Soc. 1982, 104, 352-354. (b) Jiménez-Cataño, R.; Hall, M. B. Theoretical Studies of Inorganic and Organometallic Reaction Mechanisms. 9. Intermolecular versus Intramolecular Carbon-Hydrogen Bond Activation in Zirconium, Rhodium, and Iridium Complexes. Organometallics 1996 15, 1889-1897. (c) Rodríguez, P.; Díaz-Requejo, M. M.; Belderrain, T. R.; Trofimenko, S.; Nicasio, M. C.; Pérez, P. J. Alkane Dehydrogenation by Sequential, Double $\mathrm{C}-\mathrm{H}$ Bond Activation by $\mathrm{Tp}^{\mathrm{Br} 3} \operatorname{Ir}\left(\mathrm{C}_{2} \mathrm{H}_{4}\right)_{2} \quad\left(\mathrm{Tp}^{\mathrm{Br} 3}=\right.$ hydrotris(3,4,5-tribromo)pyrazolylborate). Organometallics 2004, 23, 2162-2167. (d) Tanabe, Y.; Hanasaka, F.; Fujita, K.-I.; Yamaguchi, R. Scope and Mechanistic Studies of Intramolecular Aliphatic $\mathrm{C}-\mathrm{H}$ Bond Activation of N-Heterocyclic Carbene Iridium Complexes. Organometallics 2007, 26, 4618-4626. (e) Cheung, C. W.; Chan, K. S. Scope and Mechanistic Studies of Intramolecular Aliphatic $\mathrm{C}-\mathrm{H}$ Bond Activation of N-Heterocyclic Carbene Iridium Complexes. Organometallics 2008, 27, 3043-3055. (f) Conejero, S.; Paneque, M.; Poveda, M. L.; Santos, L. L.; Carmona, E. $\mathrm{C}-\mathrm{H}$ Bond Activation Reactions of Ethers That Generate Iridium Carbenes. Acc. Chem. Res. 2010, 43, 572-580. (g) Ito, J.-I.; Kaneda, T.; Nishiyama, H. Intermolecular C-H Bond Activation of Alkanes and Arenes by NCN Pincer Iridium(III) Acetate Complexes Containing Bis(oxazolinyl)phenyl Ligands. Organometallics 2012, 31, 44424449. (h) Donnelly, K. F.; Lalrempuia, R.; Müller-Bunz, H.; Clot, E.; Albrecht, M. Controlling the Selectivity of $\mathrm{C}-\mathrm{H}$ Activation in Pyridinium Triazolylidene Iridium Complexes: Mechanistic Details and Influence of Remote Substituents. Organometallics 2015, 34, 858869

(3) For selected sub-stoichiometric examples of iridium-catalysed $\mathrm{sp}^{3}$ C-H activation, see: (a) Yingrui, L.; Dawei, M.; Xiyan, L. Iridium Pentahydride Complex Catalyzed Formation of C-C Bond By C-H Bond Activation Followed by Olefin Insertion. Tetrahedron Lett. 1987, 28, 3249-3252. (b) DeBoef, B.; Pastine, S. J.; Sames, D. CrossCoupling of $\mathrm{sp}^{3} \mathrm{C}-\mathrm{H}$ Bonds and Alkenes: Catalytic Cyclization of Alkene-Amide Substrates. J. Am. Chem. Soc. 2004, 126, 6556-6557. (c) Tsuchikama, K.; Kasagawa, M.; Endo, K.; Shibata, T. Cationic $\operatorname{Ir}(\mathrm{I})$-Catalyzed $\mathrm{sp}^{3} \mathrm{C}-\mathrm{H}$ Bond Alkenylation of Amides with Alkynes. Org. Lett. 2009, 11, 1821-1823. (d) Zhou, M.; Schley, N. D.; Crabtree, R. H. Cp* Iridium Complexes Give Catalytic Alkane Hydroxylation with Retention of Stereochemistry. J. Am. Chem. Soc. 2010, 132, 12550-12551. (e) Pan, S.; Endo, K.; Shibata, T. Ir(I)-Catalyzed Enantioselective Secondary $\mathrm{sp}^{3} \quad \mathrm{C}-\mathrm{H}$ Bond Activation of 2(Alkylamino)pyridines with Alkenes. Org. Lett. 2011, 13, 4692-4695. (f) Kang, T.; Kim, Y.; Lee, D.; Wang, Z.; Chang, S. IridiumCatalyzed Intermolecular Amidation of $\mathrm{sp}^{3} \mathrm{C}-\mathrm{H}$ Bonds: Late-Stage Functionalization of an Unactivated Methyl Group. J. Am. Chem. Soc. 2014, 136, 4141-4144. (g) Valero, M.; Weck, R.; Güssregen, S.; Atzrodt, J.; Derdau, V. Highly Selective Directed Iridium-Catalyzed Hydrogen Isotope Exchange Reactions of Aliphatic Amides. Angew. Chem. Int. Ed., 2018, 57, 8159-8163.

(4) For recent reviews on hydrogen isotope exchange processes, see: (a) Atzrodt, J.; Derdau, V.; Fey, T.; Zimmermann, J. The Renaissance of H/D Exchange. Angew. Chem. Int. Ed. 2007, 46, 7744-7765. (b)
Heys, J. R. Organoiridium Complexes for Hydrogen Isotope Exchange Labeling. J. Labelled Compd. Radiopharm. 2007, 50, 770778. (c) Lockley, W. J. S. Hydrogen Isotope Labelling Using Iridium(I) Dionates. J. Labelled Compd. Radiopharm. 2010, 53, 668-673. (d) Salter, R. The Development and Use of Iridium(I) Phosphine Systems for ortho-Directed Hydrogen-Isotope Exchange. J. Labelled Compd. Radiopharm. 2010, 53, 645-657. (e) Allen, P. H.; Hickey, M. J. L.; Kingston, P.; Wilkinson, D. J. Metal-Catalysed Isotopic Exchange Labelling: 30 Years of Experience in Pharmaceutical R\&D. $J$ Labelled Compd. Radiopharm. 2010, 53, 731-738. (f) Atzrodt, J.; Derdau, V.; Kerr, W. J.; Reid, M. C-H Functionalisation for Hydrogen Isotope Exchange. Angew. Chem. Int. Ed. 2018, 57, 3022-3047.

(5) (a) Lockley, W. J. S. 30 Years with ortho-Directed Hydrogen Isotope Exchange Labelling. J. Labelled Compd. Radiopharm. 2007, 50, 779-788. (b) Isin, E. M.; Elmore, C. S.; Nilsson, G. N.; Thompson, R. A.; Weidolf, L. Use of Radiolabeled Compounds in Drug Metabolism and Pharmacokinetic Studies. Chem. Res. Toxicol. 2012, 25, 532-542. (c) Lockley, W. J. S.; McEwen, A.; Cooke, R. Tritium: A Coming of Age for Drug Discovery and Development ADME Studies. J. Labelled Compd. Radiopharm. 2012, 55, 235-257. (d) Atzrodt, J.; Derdau, V.; Kerr, W. J.; Reid, M. Deuterium- and Tritium-Labelled Compounds: Applications in the Life Sciences. Angew. Chem. Int. Ed. 2018, 57, 1758-1784.

(6) (a) Crabtree, R. H.; Felkin, H.; Morris, G. E. Cationic Iridium Diolefin Complexes as Alkene Hydrogenation Catalysts and the Isolation of Some Related Hydrido Complexes. J. Organomet. Chem. 1977, 141, 205-215. (b) Crabtree, R. H. Iridium Compounds in Catalysis. Acc. Chem. Res. 1979, 12, 331-337.

(7) For applications of Crabtree's catalyst in hydrogen isotope exchange see: (a) Hesk, D.; Das, P. R.; Evans, B. Deuteration of Acetanilides and Other Substituted Aromatics Using $\left[\operatorname{Ir}(\mathrm{COD})\left(\mathrm{Cy}_{3} \mathrm{P}\right)(\mathrm{Py})\right] \mathrm{PF}_{6}$ as Catalyst. J. Labelled Compd. Radiopharm. 1995, 36, 497-502. (b) Ellames, G. J.; Gibson, J. S.; Herbert, J. M.; McNeill, A. H. The Scope and Limitations of Deuteration Mediated by Crabtree's Catalyst. Tetrahedron 2001, 57, 9487-9497. (c) Bushby, N.; Killick, D. A. Hydrogen Isotope Exchange at Alkyl Positions Using Crabtree's Catalyst and its Application to the Tritiation of Methapyrilene. J. Labelled Compd. Radiopharm. 2007, 50, 519-520. (d). Schou, S. C. The Effect of Adding Crabtree's Catalyst to Rhodium Black in Direct Hydrogen Isotope Exchange Reactions. J. Labelled Compd. Radiopharm. 2009, 52, 376-381. (e) Hesk, D.; Lavey, C. F.; McNamara, P. Tritium Labelling of Pharmaceuticals by MetalCatalysed Exchange Methods. J. Labelled Compd. Radiopharm. 2010, 53, 722-730. (f) Vliegen, M.; Haspeslagh, P.; Verluyten, W. Alternative Efficient Tritium Labeling of Repaglinide. J. Labelled Compd. Radiopharm. 2012, 55, 155-157.

(8) (a) Brown, J. A.; Irvine, S.; Kennedy, A. R.; Kerr, W. J.; Andersson, S.; Nilsson, G. N. Highly Active Iridium(I) Complexes for Catalytic Hydrogen Isotope Exchange. Chem. Commun. 2008, 1115-1117. (b) Nilsson, G. N.; Kerr, W. J. The Development and Use of Novel Iridium Complexes as Catalysts for ortho-Directed Hydrogen Isotope Exchange Reactions. J. Labelled Compd. Radiopharm. 2010, 53, 662667. (c) Cochrane, A. R.; Idziak, C.; Kerr, W. J.; Mondal, B.; Paterson, L. C.; Tuttle, T.; Andersson, S.; Nilsson, G. N. Practically Convenient and Industrially-Aligned Methods for Iridium-Catalysed Hydrogen Isotope Exchange Processes. Org. Biomol. Chem. 2014, 12, 3598-3603. (d) Brown, J. A.; Cochrane, A. R.; Irvine, S.; Kerr, W. J.; Mondal, B.; Parkinson, J. A.; Paterson, L. C.; Reid, M.; Tuttle, T.; Andersson, S.; Nilsson, G. N. The Synthesis of Highly Active Iridium(I) Complexes and Their Application in Catalytic Hydrogen Isotope Exchange. Adv. Synth. Catal. 2014, 356, 3551-3562. (e) Kennedy, A. R.; Kerr, W. J.; Moir, R.; Reid, M. Anion Effects to Deliver Enhanced Iridium Catalysts for Hydrogen Isotope Exchange Processes. Org. Biomol. Chem. 2014, 12, 7927-7931. (f) Kerr, W. J.; Mudd, R. J.; Paterson, L. C.; Brown, J. A. Iridium(I)-Catalyzed Regioselective C-H Activation and Hydrogen-Isotope Exchange of NonAromatic Unsaturated Functionality. Chem. Eur. J. 2014, 20, 1460414607. (g) Atzrodt, J.; Derdau, V.; Kerr, W. J.; Reid, M.; Rojahn, P.; Weck, R. Expanded Applicability of Iridium(I) NHC/Phosphine Catalysts in Hydrogen Isotope Exchange Processes with PharmaceuticallyRelevant Heterocycles. Tetrahedron 2015, 71, 1924-1929. (h) Devlin, 
J.; Kerr, W. J.; Lindsay, D. M.; McCabe, T. J. D.; Reid, M.; Tuttle, T. Iridium-Catalysed Ortho-Directed Deuterium Labelling of Aromatic Esters-An Experimental and Theoretical Study on Directing Group Chemoselectivity. Molecules 2015, 20, 11676-11698. (i) Kerr, W. J.; Lindsay, D. M.; Reid, M.; Atzrodt, J.; Derdau, V.; Rojahn, P.; Weck, R. Iridium-Catalysed Ortho-H/D and -H/T Exchange under Basic Conditions: C-H Activation of Unprotected Tetrazoles. Chem. Commun. 2016, 52, 6669-6672. (j) Kerr, W. J.; Mudd, R. J.; Owens, P. K.; Reid, M.; Brown, J. A.; Campos, S. Hydrogen Isotope Exchange with Highly Active Iridium(I) NHC/Phosphine Complexes: A Comparative Counterion Study. J. Labelled Compd. Radiopharm. 2016, 59, 601603. (k) Kerr, W. J.; Lindsay, D. M.; Owens, P. K.; Reid, M.; Tuttle, T.; Campos, S. Site-Selective Deuteration of N-Heterocycles via Iridium-Catalyzed Hydrogen Isotope Exchange. ACS Catal. 2017, 7, $7182-7186$

(9) For the use of complexes of the type [(COD) $\operatorname{Ir}(\mathrm{NHC}) \mathrm{Cl}]$ in HIE processes, see: (a) Cochrane, A. R.; Irvine, S.; Kerr, W. J.; Reid, M.; Andersson, S.; Nilsson, G. N. Application of Neutral Iridium(I) NHeterocyclic Carbene Complexes in ortho-Directed Hydrogen Isotope Exchange. J. Labelled Compd. Radiopharm. 2013, 56, 451-454. (b) Kerr, W. J.; Reid, M.; Tuttle, T. Iridium-Catalyzed C-H Activation and Deuteration of Primary Sulfonamides: An Experimental and Computational Study. ACS Catal. 2015, 5, 402-410. (c) Burhop, A.; Weck, R.; Atzrodt, J.; Derdau, V. Hydrogen-Isotope Exchange (HIE) Reactions of Secondary and Tertiary Sulfonamides and Sulfonylureas with Iridium(I) Catalysts. Eur. J. Org. Chem. 2017, 2017, 1418-1424. (d) Kerr, W. J.; Reid, M.; Tuttle, T. Iridium-Catalyzed FormylSelective Deuteration of Aldehydes. Angew. Chem. Int. Ed. 2017, 56, 7808-7812.

(10) These complexes also find application in olefin hydrogenation; see: (a) Bennie, L. S.; Fraser, C. J.; Irvine, S.; Kerr, W. J.; Andersson, S.; Nilsson, G. N. Highly Active Iridium(I) Complexes for the Selective Hydrogenation of Carbon-Carbon Multiple Bonds. Chem. Commun. 2011, 47, 11653-11655. (b) Kerr, W. J.; Mudd, R. J.; Brown, J. A. Iridium(I) N-Heterocyclic Carbene (NHC)/Phosphine Catalysts for Mild and Chemoselective Hydrogenation Processes. Chem. Eur. J. 2016, 22, 4738-4742.

(11) (a) Yu, R. P.; Hesk, D.; Rivera, N.; Pelczer, I.; Chirik, P. J. IronCatalysed Tritiation of Pharmaceuticals. Nature 2016, 529, 195-199. (b) Palmer, W. N.; Chirik, P. J. Cobalt-Catalyzed Stereoretentive Hydrogen Isotope Exchange of $\mathrm{C}\left(\mathrm{sp}^{3}\right)-\mathrm{H}$ Bonds. ACS Catal. 2017, 7 , 5674-5678.

(12) Loh, Y. Y.; Nagao, K.; Hoover, A. J.; Hesk, D.; Rivera, N. R.; Colletti, S. L.; Davies, I. W.; MacMillan, D. W. C. PhotoredoxCatalyzed Deuteration and Tritiation of Pharmaceutical Compounds. Science 2017, 358, 1182-1187.

(13) The chosen reference compound is common within drug design. For further details see: Vitaku, E.; Smith, D. T.; Njardarson, J. T. Analysis of the Structural Diversity, Substitution Patterns, and Frequency of Nitrogen Heterocycles among U.S. FDA Approved Pharmaceuticals. J. Med. Chem. 2014, 57, 10257-10274.

(14) (a) Brereton, R. Applied Chemometrics for Scientists, 1st ed.; John Wiley \& Sons Ltd: West Sussex, U.K. 2007, p 9. (b) Leardi, R. Experimental Design in Chemistry: A Tutorial. Anal. Chim. Acta. 2009, 652, 161-172.

(15) For examples of substrate and product inhibition in similar catalytic systems, see: Heller, D.; de Vries, A. H. M.; de Vries, J. G. Catalyst Inhibition and Deactivation in Homogeneous Hydrogenation. In Handbook of Homogeneous Hydrogenation, 1st ed.; de Vries, J. G.; Elsevier, C. J., Eds.; Wiley-VCH: Weinheim, Germany 2007; pp 1494-1499.

(16) For an example of iridium interacting with unprotected amines, see: Sykes, A. C.; White, P.; Brookhart, M. Reactions of Anilines and Benzamides with a 14-Electron Iridium(I) Bis(phosphinite) Complex: $\mathrm{N}-\mathrm{H}$ Oxidative Addition versus Lewis Base Coordination. Organometallics 2006, 25, 1664-1675.

(17) Whitesides, G. M.; Hackett, M.; Brainard, R. L.; Lavalleye, J.-P P. M.; Sowinski, A. F.; Izumi, A. N.; Moore, S. S.; Brown, D. W.; Staudt, E. M. Suppression of Unwanted Heterogeneous Platinum(0)Catalyzed Reactions by Poisoning with Mercury(0) in Systems Involving Competing Homogeneous Reactions of Soluble Organoplati- num Compounds: Thermal Decomposition of Bis(Triethylphosphine)3,3,4,4-Tetramethylplatinacyclopentane. Organometallics $\mathbf{1 9 8 5}, 4$, $1819-1830$

(18) (a) Gómez-Gallego, M.; Sierra, M. A. Kinetic Isotope Effects in the Study of Organometallic Reaction Mechanisms. Chem. Rev. 2011, 111, 4857-4963. (b) Jones, W. D. Isotope Effects in C-H Bond Activation Reactions by Transition Metals. Acc. Chem. Res. 2003, 36, 140-146. 
SYNOPSIS TOC (Word Style "SN_Synopsis_TOC"). If you are submitting your paper to a journal that requires a synopsis graphic and/or synopsis paragraph, see the Instructions for Authors on the journal's homepage for a description of what needs to be provided and for the size requirements of the artwork.

Authors are required to submit a graphic entry for the Table of Contents (TOC) that, in conjunction with the manuscript title, should give the reader a representative idea of one of the following: A key structure, reaction, equation, concept, or theorem, etc., that is discussed in the manuscript. Consult the journal's Instructions for Authors for TOC graphic specifications.

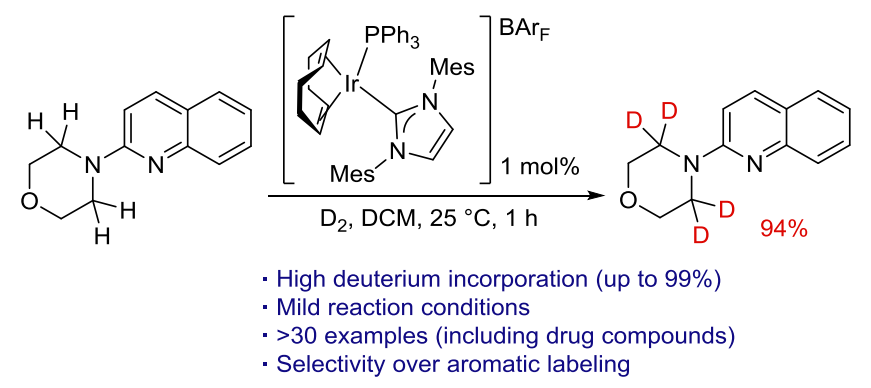




\section{Supporting Information:}

Iridium-catalyzed $\mathrm{Csp}^{3}-\mathrm{H}$ Activation for Mild and Selective Hydrogen Isotope Exchange

William J. Kerr, ${ }^{*}{ }^{\dagger}$ Richard J. Mudd, ${ }^{\dagger}$ Marc Reid, ${ }^{\dagger}$ Jens Atzrodt ${ }^{\ddagger}$ and Volker Derdau ${ }^{\ddagger}$

${ }^{\dagger}$ Department of Pure and Applied Chemistry, WestCHEM, University of Strathclyde, Glasgow, G1 1XL, Scotland, UK.

${ }^{\ddagger}$ Integrated Drug Discovery, Isotope Chemistry, Sanofi-Aventis Deutschland GmbH, Industriepark Hoechst, Frankfurt, Germany

* w.kerr@strath.ac.uk 


\section{Contents}

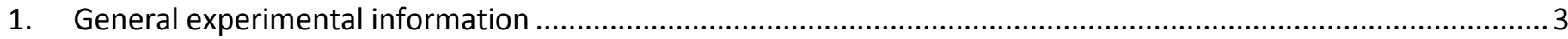

2. General procedure for exchange reactions using Heidolph synthesis 1 liquid 16 device. .................................. 7

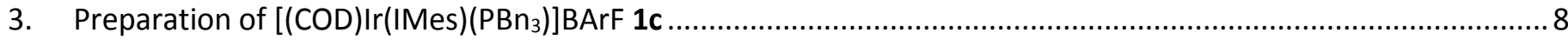

4. Screening of Catalysts 1a-1g and Extended Solvent Screen (Manuscript Table 1) .............................................9

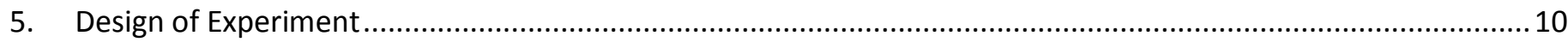

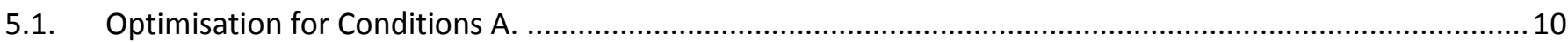

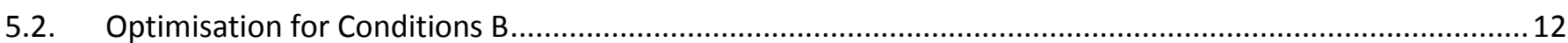

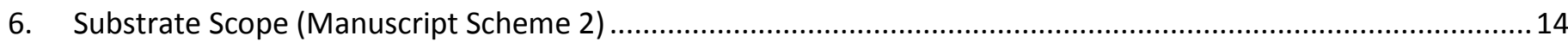

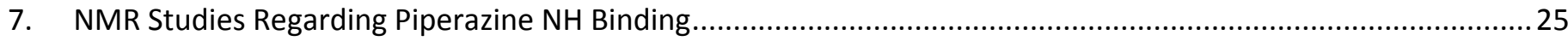

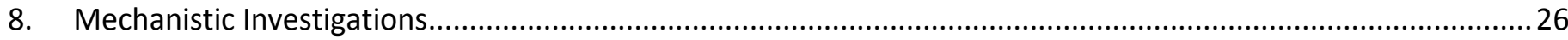

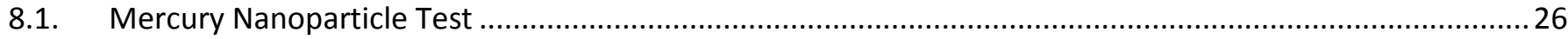

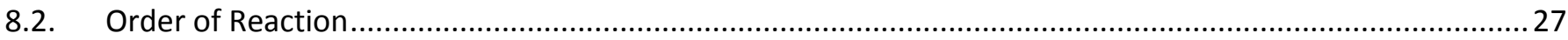

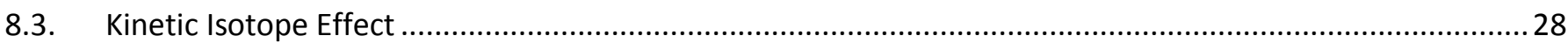

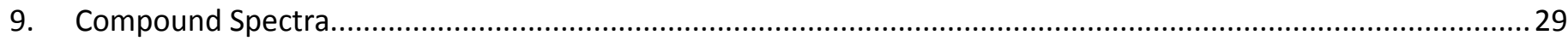

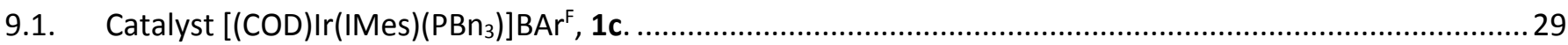

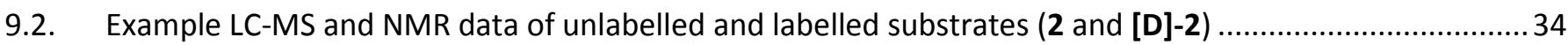

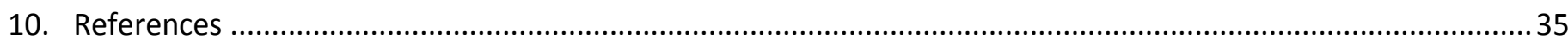




\section{General experimental information}

All reagents were obtained from commercial suppliers (Table S1) and used without further purification, unless otherwise stated. Purification was carried out according to standard laboratory methods.

Table S1. Starting materials and suppliers.

\begin{tabular}{|c|c|c|}
\hline Entry & Structure & Supplier / Synthesis \\
\hline 1 & 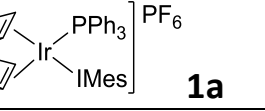 & Strem \\
\hline 2 & $\begin{array}{l}n_{3} \\
\text { es } \\
\text { BAr }^{F} \\
\quad \mathbf{1 b} \\
\end{array}$ & Prepared according to reference [1] \\
\hline 3 & s $]^{B A r^{\prime}} \quad 1 c$ & See ESI page S8 \\
\hline 4 & ]$^{\mathrm{Ph}} \mathrm{BAr}^{\mathrm{B} F} \mathbf{1 d}$ & Prepared according to reference [2] \\
\hline 5 & & Prepared according to reference [1] \\
\hline 6 & \begin{tabular}{l|l}
${ }_{3}$ & $\mathrm{PF}_{6}$ \\
& \\
& $\mathbf{1 f}$
\end{tabular} & Strem \\
\hline 7 & \begin{tabular}{|l|l}
${ }^{\prime}$ & BAr $^{F}$ \\
& \\
idine & $\mathbf{1 g}$ \\
\end{tabular} & Prepared according to reference [3] \\
\hline 8 & & Sigma-Aldrich \\
\hline 9 & 3 & Combi-Blocks \\
\hline 10 & 4 & Sigma-Aldrich \\
\hline 11 & & Sigma-Aldrich \\
\hline 12 & 6 & Alfa-Aesar \\
\hline 13 & 7 & Maybridge \\
\hline 14 & 8 & Sigma-Aldrich \\
\hline 15 & 9 & Fluorochem \\
\hline
\end{tabular}




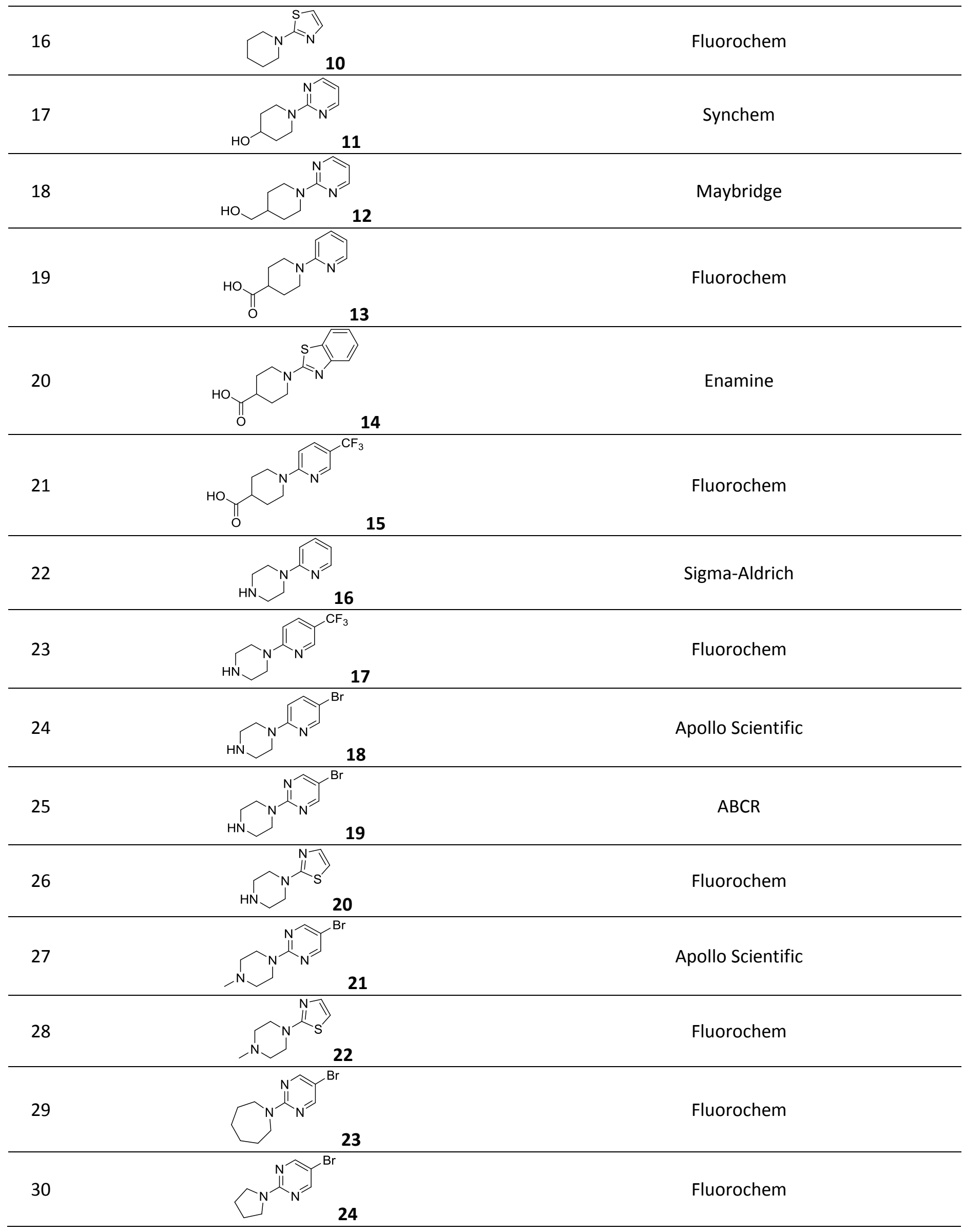




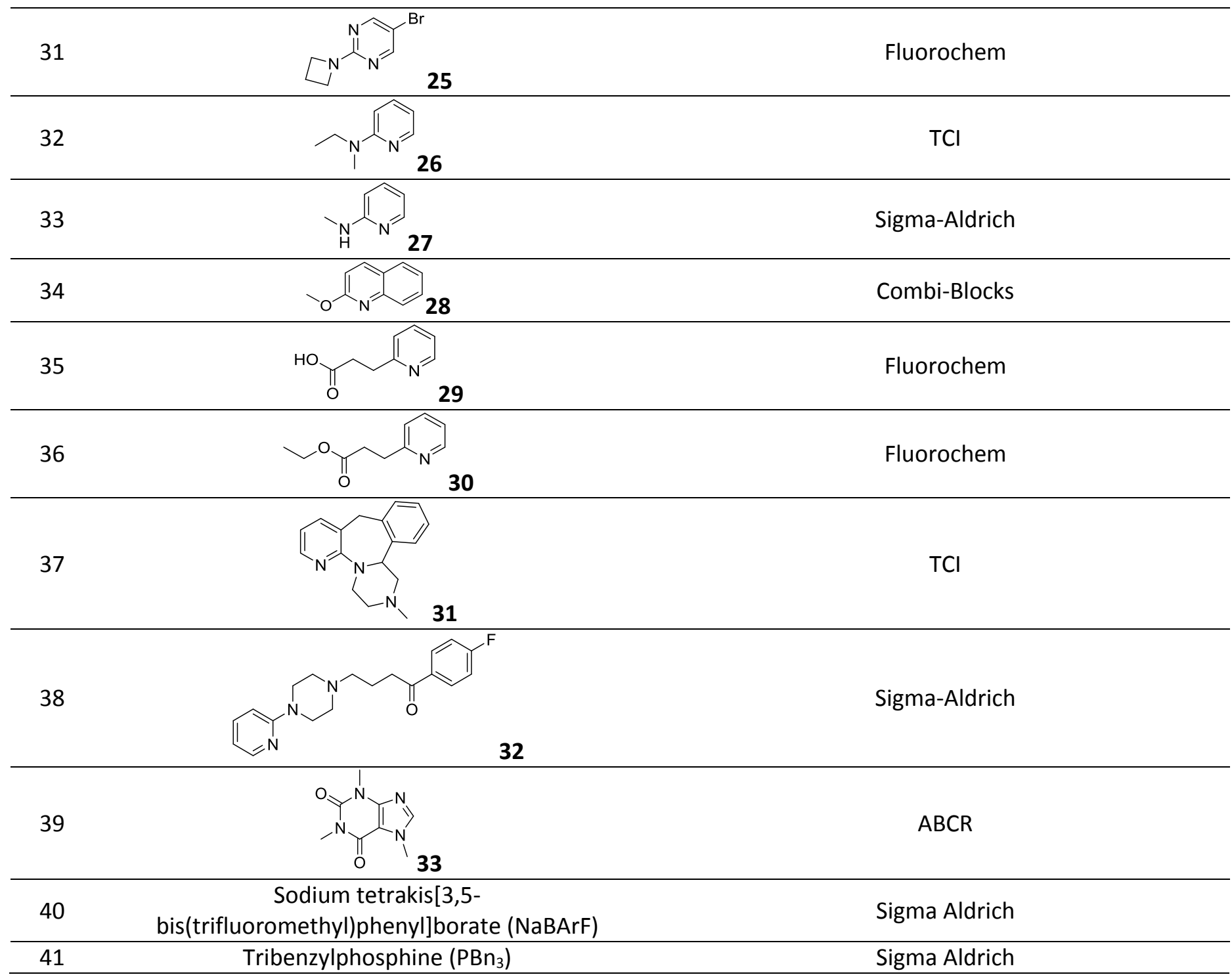

Hydrogen isotope exchange reactions were carried out on a Heidolph Synthesis 1 Liquid 16 device (Figure S1).

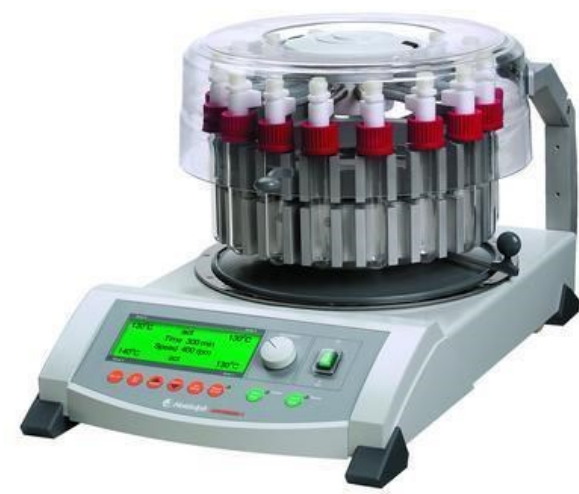

Figure S1. Heidolph synthesis 1 liquid 16 device.

${ }^{1} \mathrm{H}(300,500 \mathrm{MHz})$ and ${ }^{13} \mathrm{C}(75,125 \mathrm{MHz}) \mathrm{NMR}$ spectra were obtained on Bruker spectrometers in the solvents indicated. Chemical shifts are reported in ppm. Coupling constants are reported in $\mathrm{Hz}$ and refer to ${ }^{3} \mathrm{H}_{\mathrm{H}}$ couplings, 
unless otherwise stated. ${ }^{1} \mathrm{H}$ NMR spectra of labeled products were obtained using a 10 second delay to allow full relaxation of all hydrogen environments $(\mathrm{D} 1=10)$.

IR spectra were obtained on a Shimadzu IRAffinity-1 Spectrophotometer machine and values are reported in $\mathrm{cm}^{-1}$, unless stated otherwise.

Thin layer chromatography was carried out using Camlab silica plates coated with fluorescent indicator $\mathrm{UV}_{254}$. The plates were analysed using a Mineralight UVGL-25 lamp or developed using vanillin or $\mathrm{KMnO}_{4}$ solution.

Flash column chromatography was carried out using Prolabo silica gel (230-400 mesh).

Mass spectrometry data was acquired at the EPSRC UK National Mass Spectrometry Facility at Swansea University.

The distribution of hydrogen isotopes in the products was determined by a liquid chromatography-mass spectrometry (LC-MS) system with a Symmetry Shield RP18 column, $3.9 \times 150 \mathrm{~mm}$, with a gradient program. LC column conditions were as follows:

Mobile phase A: water $(900 \mathrm{~mL})$, acetonitrile $(100 \mathrm{~mL})$, TFA $(1 \mathrm{~mL})$

Mobile phase B: water $(100 \mathrm{~mL})$, acetonitrile $(900 \mathrm{~mL})$, TFA $(1 \mathrm{~mL})$

Gradient program: $\quad 0-4$ min: $5 \%$ A/95\% B

4-7 $\min : 10 \% A / 90 \% B$

Flow rate: $1.0 \mathrm{~mL} / \mathrm{min}$

Detection: UV $254 \mathrm{~nm}$. 


\section{General procedure for exchange reactions using Heidolph synthesis 1 liquid 16 device.}

The apparatus was evacuated then filled with argon, and the water condenser was turned on. To a carousel tube was added the substrate of choice $(0.086 \mathrm{mmol})$, and iridium catalyst $(0.00086 \mathrm{mmol}(1 \mathrm{~mol} \%)$ or $0.00215 \mathrm{mmol}(2.5$ mol\%) or $0.0043 \mathrm{mmol}(5 \mathrm{~mol} \%))$. The requisite solvent was then added, rinsing the inner walls of the tube. The tube was then sealed at the screw cap (with the gas inlet left open) under argon. The flask was then twice evacuated and refilled with deuterium via a balloon. The carousel gas inlet tube was then closed, creating a sealed atmosphere of deuterium, the carousel shaking motion was initiated $(750 \mathrm{rpm})$ and the temperature set $\left(25^{\circ} \mathrm{C}\right.$ unless otherwise stated). After starting the device, the timer was initiated and a rapid red/orange to clear/yellow colour change was observed. The reaction mixture was stirred for the allotted time ( $1 \mathrm{~h}$ or $3 \mathrm{~h}$ ) before removing excess deuterium and replacing with air. The yellow solution was then prepared for analysis by LC-MS and ${ }^{1} \mathrm{H}$ NMR spectroscopy.

The level and regioselectivity of deuterium incorporation in the substrate was determined by ${ }^{1} \mathrm{H}$ NMR spectroscopy. The integrals were calibrated against a peak corresponding to a position not expected to be labelled. Equation 1 was then used to calculate the extent of labelling.

$$
\% \text { Deuteration }=100-\left[\left(\frac{\text { residual integral }}{\text { number of exchangeable sites }}\right) \times 100\right]
$$

\section{Equation 1}

For example, in a substrate containing four possible positions of exchange, the percentage given refers to the level of deuterium incorporation over the total number of positions (see page S34 for an example of such a spectrum).

The incorporation of deuterium into each substrate was verified by LC-MS, observing a shift in the isotope distribution in the starting material $(M)$ to show $M+1\left(d_{1}\right), M+2\left(d_{2}\right), M+3\left(d_{3}\right)$, etc.

Example LC-MS analysis of compound 2:

$\sim 5 \mu \mathrm{L}$ of the labelling reaction mixture was removed and diluted with $0.5 \mathrm{~mL}$ of $\mathrm{MeCN}$, and the sample analysed by LC-MS. Data processing was performed using ADvion Mass express analysis software and the given formula:

\begin{tabular}{|l|l|l|l|l|l|}
\hline \# of D atoms incorporated & $\mathrm{D} 0$ & $\mathrm{D} 1$ & $\mathrm{D} 2$ & $\mathrm{D} 3$ & $\mathrm{D} 4$ \\
\hline Integral of MS peak & 0 & 0.2 & 0.23 & 1.2 & 1.3 \\
\hline Percentage & $0 \%$ & $6.3 \%$ & $15.6 \%$ & $37.5 \%$ & $40.6 \%$ \\
\hline
\end{tabular}

$$
\begin{gathered}
\text { Total incorporation }=(\% \mathrm{D} 1 \times 0.25)+(\% \mathrm{D} 2 \times 0.5)+(\% \mathrm{D} 3 \times 0.75)+(\% \mathrm{D} 4 \times 1) \\
\text { Total incorporation }=(6.3 \times 0.25)+(15.6 \times 0.5)+(37.5 \times 0.75)+(40.6 \times 1) \\
\text { Total incorporation }=(1.6)+(7.8)+(28.1)+(40.6)=78.1 \%
\end{gathered}
$$




\section{Preparation of [(COD)Ir(IMes)(PBn 3$)] B A r F 1 C$}

The catalyst was prepared according to a modified procedure from reference [1].

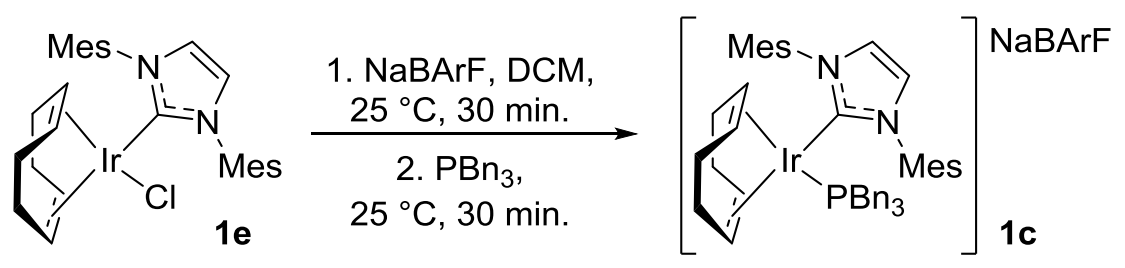

To a flame-dried, argon-cooled Schlenk tube was added IMes/chloride complex $1 \mathrm{e}^{1}$ (320 mg, $0.5 \mathrm{mmol}, 1 \mathrm{eq}$ ), dry DCM $(10 \mathrm{~mL})$ and $\mathrm{NaBAr}^{\mathrm{F}}(443 \mathrm{mg}, 0.5 \mathrm{mmol}, 1 \mathrm{eq})$. After stirring at $25^{\circ} \mathrm{C}$ for $30 \mathrm{~min}$, tribenzylphosphine $(152 \mathrm{mg}$, $0.5 \mathrm{mmol}, 1 \mathrm{eq}$ ) was added slowly, initiating an orange to red colour change. Following a further $30 \mathrm{~min}$ stirring, the solvent was removed in vacuo leaving a red oily solid. The residue was purified by flash column chromatography, eluting with $\mathrm{DCM} /$ petroluem ether $40-60{ }^{\circ} \mathrm{C}(50 / 50)$. The isolated catalyst was dried in a vacuum oven $\left(40{ }^{\circ} \mathrm{C}, 1\right.$ mbar) for $24 \mathrm{~h}$, yielding $1 \mathrm{c}$ as a deep red solid ( $762 \mathrm{mg}, 86 \%$ yield).

Melting Point $\left({ }^{\circ} \mathrm{C}\right):>175$ (dec).

FTIR (neat): (cm-1): 2978, 2361, 1495.

${ }^{1} \mathrm{H}$ NMR $\left(400 \mathrm{MHz}, \mathrm{CDCl}_{3}\right): \delta 7.79\left(8 \mathrm{H}, \mathrm{t}^{4} \mathrm{~J}=2.3 \mathrm{~Hz}, \mathrm{Ar}-\underline{H}\right), 7.58(4 \mathrm{H}, \mathrm{s}, \mathrm{Ar}-\underline{\mathrm{H}}), 7.37-7.27(13 \mathrm{H}, \mathrm{m}, \mathrm{Ar}-\underline{\mathrm{H}}), 7.25-7.21(2 \mathrm{H}$,

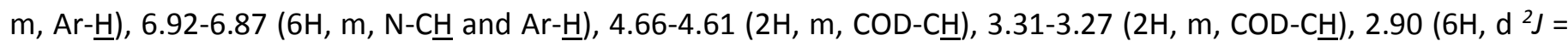
$\left.8.7 \mathrm{~Hz}, \mathrm{P}-\mathrm{CH}_{2}-\mathrm{Ar}\right), 2.51\left(6 \mathrm{H}, \mathrm{s}, \mathrm{Ar}-\mathrm{CH}_{3}\right), 2.50\left(6 \mathrm{H}, \mathrm{s}, \mathrm{Ar}-\mathrm{CH}_{3}\right), 2.33\left(6 \mathrm{H}, \mathrm{s}, \mathrm{Ar}-\mathrm{CH}_{3}\right), 1.86-1.73\left(2 \mathrm{H}, \mathrm{m}, \mathrm{COD}-\mathrm{CH}_{2}\right), 1.65-$ $1.49\left(4 \mathrm{H}, \mathrm{m}, \mathrm{COD}-\mathrm{CH}_{2}\right), 1.43-1.32\left(2 \mathrm{H}, \mathrm{m}, \mathrm{COD}-\mathrm{CH}_{2}\right)$.

${ }^{13} \mathrm{C}$ NMR $\left(101 \mathrm{MHz}, \mathrm{CDCl}_{3}\right): \delta 176.5\left(\mathrm{~d}^{2} J_{C-P}=7.7 \mathrm{~Hz}\right), 161.2\left(\mathrm{q}^{1} J_{C-B}=49.5 \mathrm{~Hz}\right), 140.4,135.6,135.3,134.3,134.2,132.2$, $132.1,130,0,129.5,129.33,129.28,128.4\left(q^{2} J_{C-F}=32.9 \mathrm{~Hz}\right), 128.3,127.1,125.7,124.1\left(q^{1} J_{C-F}=269 \mathrm{~Hz}\right), 116.9,86.1$, $85.9,75.5,31.3,31.0,30.0,29.7,20.5,19.6,19.0$.

${ }^{31} \mathrm{P}$ NMR $\left(162 \mathrm{MHz}, \mathrm{CDCl}_{3}\right): \delta-7.98\left(\mathrm{PBn}_{3}\right)$.

${ }^{19} \mathrm{~F}$ NMR (376 MHz, $\left.\mathrm{CDCl}_{3}\right): \delta-62.42$ (BArF).

${ }^{11}$ B NMR (128 MHz, $\left.\mathrm{CDCl}_{3}\right): \delta-6.65$ (BArF).

HRMS (NSI): $\mathrm{m} / \mathrm{z}$ calculated for $\mathrm{C}_{50} \mathrm{H}_{57} \mathrm{IrN}_{2} \mathrm{P}[\mathrm{M}]^{+}: 607.3867$; found: 607.3860 .

See page S29 for spectra. 


\section{Screening of Catalysts 1a-1g and Extended Solvent Screen (Manuscript Table 1)}

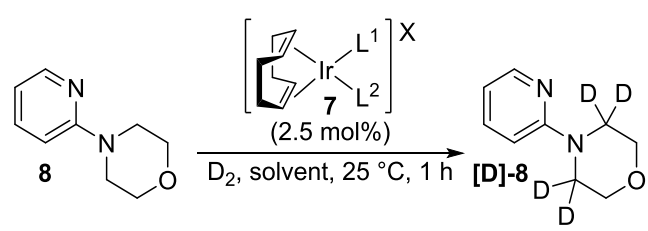

Reactions were carried out following the general procedure on page S7, using 4-(pyridin-2-yl)morpholine 2 (14.1 mg, $0.086 \mathrm{mmol}, 1 \mathrm{eq})$, with catalyst $(0.00215 \mathrm{mmol}, 2.5 \mathrm{~mol} \%)$ in $1 \mathrm{~mL}$ of solvent $(0.086 \mathrm{M})$ under $\mathrm{D}_{2}$ for $1 \mathrm{~h}$ at $25^{\circ} \mathrm{C}$. The full details are tabulated below in Table S2. Entries 11-15 are supplementary to the manuscript Table 1 entries.

Each reaction was performed in duplicate. The deuterium incorporation was analysed by LCMS and the deuterium distribution was confirmed by ${ }^{1} \mathrm{H}$ NMR spectroscopy.

Table S2. Screening of Catalysts 1a-1g and Extended Solvent Screen.

\begin{tabular}{|c|c|c|c|c|c|c|}
\hline \multirow{2}{*}{ Entry } & \multirow{2}{*}{ Complex } & \multirow{2}{*}{$\begin{array}{l}\text { mass }(\mathrm{mg}) \text { of } \\
\text { catalyst used }\end{array}$} & \multirow{2}{*}{ Solvent } & \multicolumn{3}{|c|}{ Deuterium Incorporation (\%D) } \\
\hline & & & & Run 1 & Run 2 & Average \\
\hline 1 & $\left.\begin{array}{c}\mathrm{PPh}_{3} \\
\mathrm{IMes}^{\mathrm{PF}}\end{array}\right]^{\mathrm{PF}}$ & 2.2 & DCM & 76 & 81 & 79 \\
\hline 2 & $\left.\begin{array}{l}h_{3} \\
\text { es }\end{array}\right]^{\text {BAr }}$ & 3.7 & DCM & 88 & 92 & 90 \\
\hline 3 & $\left.\begin{array}{l}n_{3} \\
\text { es }\end{array}\right]^{B A r}$ & 3.8 & DCM & 85 & 84 & 85 \\
\hline 4 & $\left.{ }_{2} \mathrm{Ph}\right]^{\mathrm{B}}$ & 3.5 & DCM & 75 & 81 & 78 \\
\hline 5 & les & 1.4 & DCM & 0 & 0 & 0 \\
\hline 6 & ridine & 1.7 & DCM & 26 & 22 & 24 \\
\hline 7 & dine $]^{\mathrm{B}}$ & 3.3 & DCM & 25 & 26 & 26 \\
\hline 8 & $\left.\begin{array}{l}3 \\
3\end{array}\right]$ & 3.7 & $t$-AmylOH & 76 & 75 & 76 \\
\hline 9 & $\left.\begin{array}{l}3 \\
s\end{array}\right]^{B A r}$ & 3.7 & MTBE & 87 & 86 & 87 \\
\hline 10 & |BAr & 3.7 & $t$-BuOAc & 86 & 86 & 86 \\
\hline 11 & BAr & 3.7 & $\mathrm{MeOH}$ & 65 & 67 & 66 \\
\hline 12 & & 3.7 & $i-\mathrm{PrOH}$ & 60 & 55 & 58 \\
\hline 13 & $\begin{array}{l}{ }_{3} \text { BAr } \\
\text { sAr }\end{array}$ & 3.7 & 2-MeTHF & 64 & 73 & 69 \\
\hline 14 & $\left.\begin{array}{l}h_{3} \\
\text { es }\end{array}\right]^{\text {BAr }}$ & 7.4 & CPME & 83 & 83 & 83 \\
\hline 15 & $\begin{array}{l}\mathrm{h}_{3} \\
\mathrm{es}\end{array}$ & 3.7 & $i$-PrOAc & 80 & 72 & 76 \\
\hline
\end{tabular}




\section{Design of Experiment}

\subsection{Optimisation for Conditions A.}

Experimental design was used to assess the effect of varying catalyst loading, reaction time, and reaction concentration [Conditions: $\mathbf{2}$ (14.1 mg, $0.086 \mathrm{mmol}), \mathbf{1 b}$ (catalyst loading), DCM (concentration), $\mathrm{D}_{2}, 25{ }^{\circ} \mathrm{C}$, (reaction time)]. As such, 'high' and 'low' values for each of these three variables were chosen. To generate a series of experiments to study optimal conditions within the variable ranges chosen, Design Expert ${ }^{\mathrm{TM}}$ software v9.0 (Stat_Ease Inc., Minneappolis, Mn) was used. This generated a 2 level, 3 factorial design containing three centre points, giving 11 experiments in total. The deuterium incorporation of 4-(pyridin-2-yl)morpholine 2 was used as the response (Table S3).

Table S3. Design of Experiment: Optimisation for Protocol 1

\begin{tabular}{cccccc}
\hline Run & $\begin{array}{c}\text { Variable A: } \\
\text { Catalyst Loading (mol\%) }\end{array}$ & $\begin{array}{c}\text { Amount of 1b } \\
(\mathbf{m g}(\mathbf{m m o}))\end{array}$ & $\begin{array}{c}\text { Variable B: } \\
\text { Reaction Time (min) }\end{array}$ & $\begin{array}{c}\text { Variable C: } \\
\text { DCM Volume } \\
(\mathbf{m L})\end{array}$ & $\begin{array}{c}\text { Response: } \\
\text { Incorporation (\%D) }\end{array}$ \\
\hline $1(++-)$ & 1.5 & $2.2(0.00129)$ & 40 & 0.5 & 52 \\
\hline $2(--+)$ & 0.5 & $0.7(0.0043)$ & 20 & 2.5 & 24 \\
\hline $3(+++)$ & 1.5 & $2.2(0.00129)$ & 40 & 2.5 & 94 \\
\hline $4(000)$ & 1.0 & $1.5(0.00086)$ & 30 & 1.5 & 72 \\
\hline $5(-+-)$ & 0.5 & $0.7(0.0043)$ & 40 & 0.5 & 45 \\
\hline $6(000)$ & 1.0 & $1.5(0.00086)$ & 30 & 1.5 & 73 \\
\hline $7(--)$ & 0.5 & $0.7(0.0043)$ & 20 & 0.5 & 30 \\
\hline $8(+--)$ & 1.5 & $2.2(0.00129)$ & 20 & 0.5 & 51 \\
\hline $9(000)$ & 1.0 & $1.5(0.00086)$ & 30 & 1.5 & 69 \\
\hline $10(-++)$ & 0.5 & $0.7(0.0043)$ & 40 & 2.5 & 37 \\
\hline $11(+-+)$ & 1.5 & $2.2(0.00129)$ & 20 & 2.5 & 70 \\
\hline${ }^{a}(+)=$ high value, (-) low value, and (0) $=$ centre point of a variable. (-+-) = combination of low A, high B, and low C \\
\hline
\end{tabular}

Entries 4, 6, and 9 represent the centre points of the design. These were employed in order to:

(i) assess any curvature in the response of conversion changes in the variables; and

(ii) assess the repeatability of the hydrogen isotope exchange reaction.

A response surface was created in the same design program. This generated a half-normal plot (Graph S1), inferring that increasing the catalyst loading, reaction time, DCM volume, and the combination of catalyst loading and DCM volume have a positive impact upon the efficacy of the labeling reaction. 
Design-Expert巴 Software Incorporation

$\Delta$ Error estimates

B: Reaction Time

C: DCM Volume

․ Positive Effects
a Negative Effects

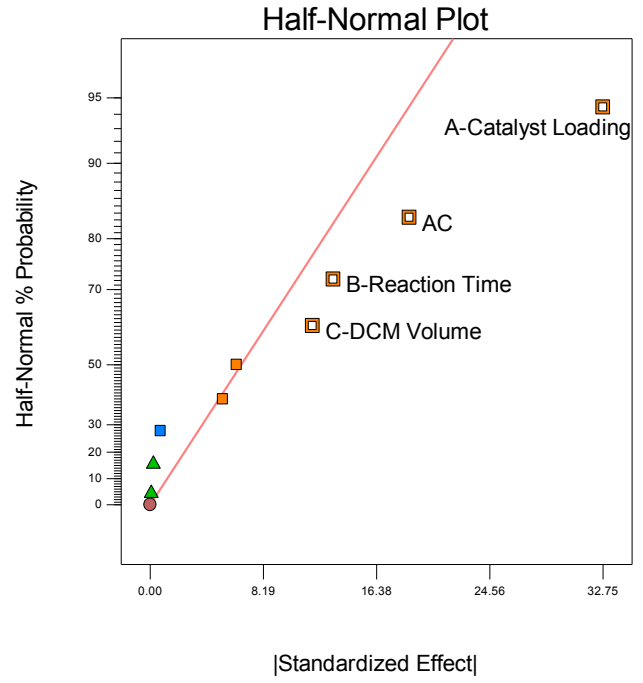

Graph S1

Finally, provided below is a graph of Residuals versus Predicted plot. This is a plot of the residuals versus the ascending predicted response values (lower conversion to higher conversion) and tests the assumption of constant variance in the data (Graph S2).

Design-Expert@ Software (adjusted for curvature) Color points by value of Incorporation: 94

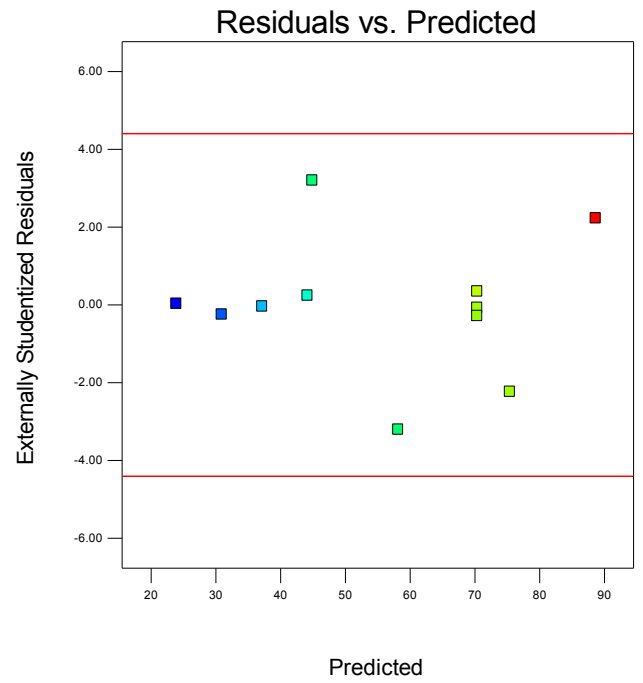

Graph S2 


\subsection{Optimisation for Conditions B}

Experimental design was used to assess the effect of varying catalyst loading, reaction time, and reaction concentration [Conditions: 16 (14.0 mg, $0.086 \mathrm{mmol}), \mathbf{1 b}$ (catalyst loading), DCM (concentration), $\mathrm{D}_{2}, 25^{\circ} \mathrm{C}$, (reaction time)]. As such, 'high' and 'low' values for each of these three variables were chosen. To generate a series of experiments to study optimal conditions within the variable ranges chosen, Design Expert ${ }^{\mathrm{TM}}{ }^{\mathrm{T}}$ software v9.0 (Stat_Ease Inc., Minneappolis, $\mathrm{Mn}$ ) was used. This generated a 2 level, 3 factorial design containing three centre points, giving 11 experiments in total. The deuterium incorporation of 4-(pyridin-2-yl)piperazine 16 was used as the response (Table S4).

Table S4. Design of Experiment: Optimisation for Protocol 2

\begin{tabular}{|c|c|c|c|c|c|}
\hline Run $^{a}$ & $\begin{array}{c}\text { Variable A: } \\
\text { Catalyst Loading (mol\%) }\end{array}$ & $\begin{array}{l}\text { Amount of } 1 b \\
(\mathrm{mg}(\mathrm{mmol}))\end{array}$ & $\begin{array}{c}\text { Variable B: } \\
\text { Reaction Time }(\mathrm{min})\end{array}$ & $\begin{array}{c}\text { Variable C: } \\
\text { DCM Volume } \\
(\mathrm{mL})\end{array}$ & $\begin{array}{c}\text { Response: } \\
\text { Incorporation (\%D) }\end{array}$ \\
\hline $1(000)$ & 3.0 & 4.5 & 75 & 1.5 & 62 \\
\hline $2(+++)$ & 5.0 & 7.4 & 120 & 2.5 & 83 \\
\hline $3(+--)$ & 5.0 & 7.4 & 30 & 0.5 & 48 \\
\hline $4(--+)$ & 1.0 & 1.5 & 30 & 2.5 & 7 \\
\hline $5(000)$ & 3.0 & 4.5 & 75 & 1.5 & 62 \\
\hline $6(++-)$ & 5.0 & 7.4 & 120 & 0.5 & 69 \\
\hline $7(---)$ & 1.0 & 1.5 & 30 & 0.5 & 5 \\
\hline $8(-+-)$ & 1.0 & 1.5 & 120 & 0.5 & 10 \\
\hline $9(-++)$ & 1.0 & 1.5 & 120 & 2.5 & 14 \\
\hline $10(+-+)$ & 5.0 & 7.4 & 30 & 2.5 & 57 \\
\hline $11(000)$ & 3.0 & 4.5 & 75 & 1.5 & 64 \\
\hline
\end{tabular}

Entries 1, 5, and 11 represent the centre points of the design. These were employed in order to:

(i) assess any curvature in the response of conversion changes in the variables; and

(ii) assess the repeatability of the hydrogen isotope exchange reaction.

A response surface was created in the same design program. This generated a half-normal plot (Graph S3), inferring that increasing the catalyst loading, reaction time, DCM volume, and the combination of catalyst loading and DCM volume have a positive impact upon the efficacy of the labelling reaction.
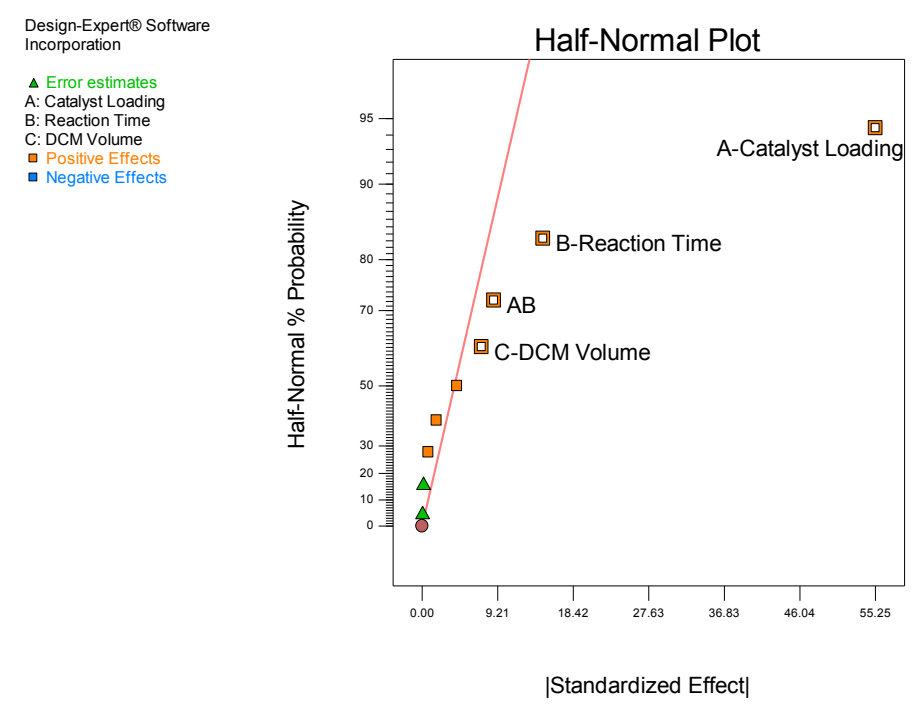
Finally, provided below is a graph of Residuals versus Predicted plot. This is a plot of the residuals versus the ascending predicted response values (lower conversion to higher conversion) and tests the assumption of constant variance in the data (Graph S4).

Design-Expert@ Software (adjusted for curvature)

Color points by value of Incorporation

$\prod_{5}^{83}$

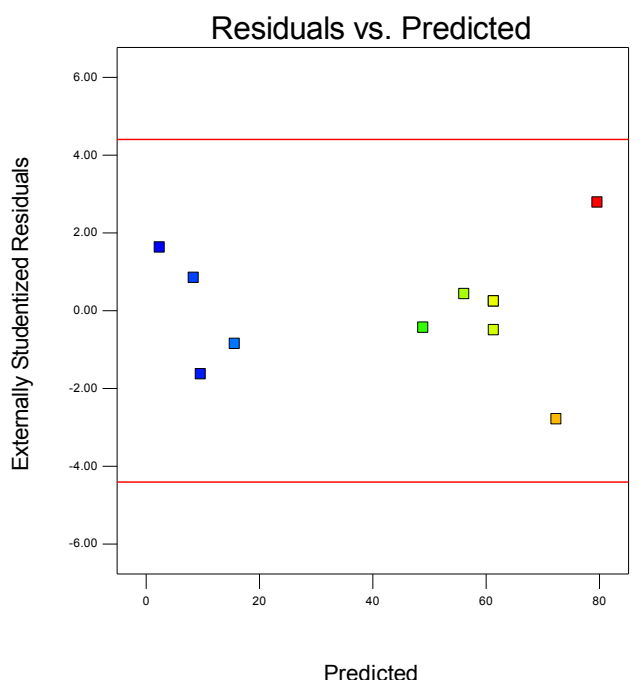

Graph S4 


\section{Substrate Scope (Manuscript Scheme 2)}

$$
\text { [Conditions] }
$$

\section{Conditions $A$}

Reactions were carried out following the general procedure on page $\mathrm{S7}$, using substrate $(0.086 \mathrm{mmol}, 1 \mathrm{eq})$, with catalyst $\mathbf{1 b}(1.5 \mathrm{mg}, 0.00086 \mathrm{mmol}, 1.0 \mathrm{~mol} \%)$ in $1 \mathrm{~mL}$ of DCM $(0.086 \mathrm{M})$ under $\mathrm{D}_{2}$ for $1 \mathrm{~h}$ at $25^{\circ} \mathrm{C}$.

\section{Conditions $B$}

Reactions were carried out following the general procedure on page $\mathrm{S7}$, using substrate $(0.086 \mathrm{mmol}, 1 \mathrm{eq})$, with catalyst $1 \mathrm{~b}(7.4 \mathrm{mg}, 0.0043 \mathrm{mmol}, 5.0 \mathrm{~mol} \%)$ in $1 \mathrm{~mL}$ of DCM $(0.086 \mathrm{M})$ under $\mathrm{D}_{2}$ for $3 \mathrm{~h}$ at $25^{\circ} \mathrm{C}$.

Each reaction was performed in duplicate. The extent and position of labeling was established using ${ }^{1} \mathrm{H}$ NMR spectroscopy. The average deuterium incorporation for each molecule across all labeled positions was further confirmed by LCMS analysis. The details of the substrate scope described within the manuscript are given in Table $\mathbf{5 5}$ below.

Table S5. Substrate Scope.

\begin{tabular}{|c|c|c|c|c|c|c|c|}
\hline \multirow{3}{*}{ Entry } & \multirow{3}{*}{ Substrate } & \multirow{3}{*}{$\begin{array}{c}\text { Mass of } \\
\text { Substrate } \\
\text { Used (mg) }\end{array}$} & \multirow{3}{*}{ Protocol } & \multicolumn{4}{|c|}{ Deuterium Incorporation (\%D) } \\
\hline & & & & \multicolumn{3}{|c|}{ LC-MS } & \multirow{2}{*}{$\begin{array}{c}{ }^{1} \mathrm{H} \text { NMR } \\
\text { Distribution }\end{array}$} \\
\hline & & & & Run 1 & Run 2 & Average & \\
\hline 1 & & 14.1 & A & 82 & 78 & 80 & 80 \\
\hline 2 & & 21.0 & A & 95 & 95 & 95 & 95 \\
\hline 3 & & 18.4 & A & 85 & 91 & 88 & 94 \\
\hline 4 & & 18.4 & A & 96 & 92 & 94 & 99 \\
\hline \multirow{3}{*}{5} & & \multirow{3}{*}{18.0} & \multirow{3}{*}{ A } & \multirow{3}{*}{85} & \multirow{3}{*}{86} & \multirow{3}{*}{86} & $D^{a}=87$ \\
\hline & & & & & & & $D^{b}=91$ \\
\hline & & & & & & & $D^{c}=57$ \\
\hline
\end{tabular}


6 [D]-7 $_{D_{D^{a}}}$

19.1

A $\quad 82$

83

$D^{\mathrm{a}}=95$

$7 \underbrace{C_{T^{2}}^{D}}_{\text {[D]-8 }}$

11.1

$\begin{array}{lllll}\text { A } & 0 & 0 & 0 & 0\end{array}$

$8 \underbrace{T^{D}}_{D}$

20.8

A $\quad 94 \quad 96$

95

91

[D]-9

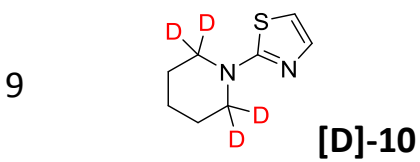

14.5

A

78

82

80

86

10<smiles>[2H][C@@]1(O)CC(O)C[13C]([2H])([2H])N1c1ncccn1</smiles>

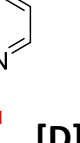

[D]-11

15.4

A

88

90

$$
\mathrm{D}_{\mathrm{ax}}=83
$$

11<smiles>[2H][C@]1(O)CC(CO)C[13C]([2H])([2H])N1c1ncccn1</smiles>

16.6

A

89

89

$D_{a x}=86$

[D]-12

12<smiles>[2H]C1([2H])CC(C(=O)O)C[13C]([2H])([2H])N1c1ccccn1</smiles>

17.7

A

78

83

$D_{a x}=73$

[D]-13

13

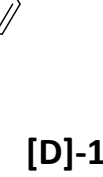

22.6

$\mathrm{A}^{* *}$

83

81

82

[D]-14

14

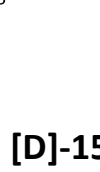

23.6

$\begin{array}{ll}\text { A } & 95\end{array}$

89

$D_{a x}=90$

[D]-15 
$\begin{array}{lll}\text { A } & 17 & 18\end{array}$

18

18

[D]-16

B 90

94

92

89

16

$\underbrace{D^{a}}_{D^{a}}$

[D]-17

19.9

A $\quad 11$

12

12

12

70

67

25

20.8

A $\quad 24$

$\underbrace{D^{a}}_{D^{a}} \overbrace{D^{b}}^{B r}$

[D]-18

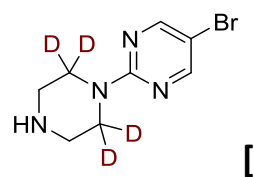

[D]-19

20.9

A 7

86

86

86

25

$D^{b}=0$

$D^{a}=92$

$D^{b}=34$

18<smiles>[2H]C1([2H])CNCC([2H])([2H])N1c1nccs1</smiles>

14.6

19

22

30

19

[D]-20

89
90

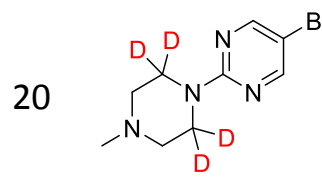

[D]-21

22.1 A 87

94

91

92

21
[D]-22

\section{[D]-22}

$15.8 \quad \mathrm{~A}$

87

82

85

84

$22 \underbrace{x^{D} N^{n} \overbrace{}^{n}}_{x^{D}}$

$Y^{B r}$

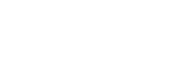

A $\quad 47$

47

47

47

[D]-23

22.0

B $\quad 86$

84

85

84

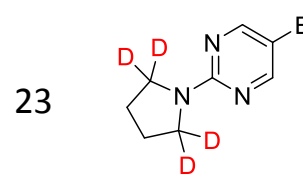

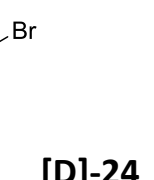

19.

A 58

[D]-24

B

94

94

94

94 
$24 \sum_{D}^{D}$

[D]-25

25<smiles></smiles>

[D]-26
A $\quad 0$
0

0

0

0

18.4

$\begin{array}{lllll}\text { B } & 8 & 9 & 9 & 9\end{array}$

25

\begin{tabular}{|c|c|c|c|c|c|}
\hline \multirow{2}{*}{\multicolumn{2}{|c|}{ A }} & \multirow{2}{*}{0} & \multirow{2}{*}{0} & \multirow{2}{*}{0} & $\mathrm{D}^{\mathrm{a}}=0$ \\
\hline & & & & & $D^{b}=0$ \\
\hline \multirow{2}{*}{11.7} & \multirow[b]{2}{*}{ B } & \multirow[b]{2}{*}{96} & \multirow{2}{*}{95} & \multirow{2}{*}{96} & $D^{a}=92$ \\
\hline & & & & & $D^{b}=92$ \\
\hline
\end{tabular}

26
A 0
0
0
0

9.3

\begin{tabular}{lllll}
\hline B & 32 & 28 & 30 & 37
\end{tabular}

27

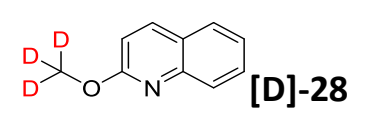

13.7

A 13

15

14

14

13.7

B $\quad 70$

28 (D)

\section{[D]-29}

13.0

A 16

77

74

80

$29 \sum_{0}^{D^{a}}$

[D]-30

A

15.4

A

19

18

16

B $\quad 58$

63

61

65

37

$\sqrt{2}$

14


${ }^{1} \mathrm{H}$ NMR (300 MHz, DMSO-d $\mathrm{d}_{6}$ ): $\delta 8.12\left(1 \mathrm{H}, \mathrm{dd}, J=5.1 \mathrm{~Hz},{ }^{4} J=1.5 \mathrm{~Hz}, \mathrm{Ar}-\underline{\mathrm{H}}\right), 7.54$ $\left(1 \mathrm{H}, \mathrm{ddd}, J=8.7 \mathrm{~Hz}, 7.1 \mathrm{~Hz},{ }^{4} J=1.5 \mathrm{~Hz}, \mathrm{Ar}-\underline{\mathrm{H}}\right), 6.81(1 \mathrm{H}, \mathrm{d}, J=8.7 \mathrm{~Hz}, \mathrm{Ar}-\underline{\mathrm{H}}), 6.66$

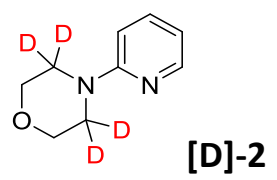
$\left(1 \mathrm{H}, \mathrm{dd}, J=7.7 \mathrm{~Hz},{ }^{4} J=5.1 \mathrm{~Hz}, \mathrm{Ar}-\underline{\mathrm{H}}\right), 3.72-3.64\left(4 \mathrm{H}, \mathrm{m}, \mathrm{O}-\mathrm{CH}_{2}\right), 3.44-3.37(4 \mathrm{H}$, $\left.\mathrm{m}, \mathrm{N}-\mathrm{CH}_{2}\right)$. Incorporation expected at $\delta 3.44-3.37$. Determined against integral at $\delta 6.66$.

\section{LCMS data}

Retention time: $0.28 \mathrm{~min}$; Mass ion: $165.1(\mathrm{M}+\mathrm{H})^{+}$

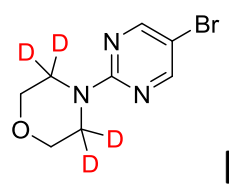

[D]-3

\section{${ }^{1} \mathrm{H}$ NMR data $^{5}$}

${ }^{1} \mathrm{H}$ NMR (300 MHz, DMSO-d 6 ): $\delta 8.46$ (2H, s, Ar- $\left.\underline{\mathrm{H}}\right), 3.70-3.60\left(8 \mathrm{H}, \mathrm{m}, \mathrm{CH}_{2}\right)$. Incorporation expected at $\delta 3.70-3.60$.

Determined against integral at $\delta 8.46$.

Retention time: 2.69 min; Mass ion: $244.1(\mathrm{M}+\mathrm{H})^{+}$[using ${ }^{79} \mathrm{Br}$ ]

\section{${ }^{1} \mathrm{H}$ NMR data}

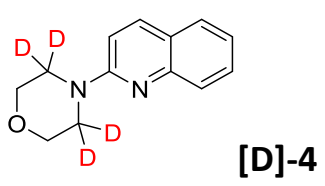

${ }^{1} \mathrm{H}$ NMR (300 MHz, DMSO-d $\left.\mathrm{d}_{6}\right): \delta 8.05(1 \mathrm{H}, \mathrm{d}, J=9.3 \mathrm{~Hz}, \mathrm{Ar}-\underline{\mathrm{H}}), 7.70(1 \mathrm{H}, \mathrm{d}, J=$

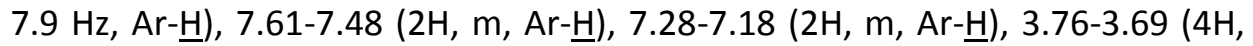
$\left.\mathrm{m}, \mathrm{O}-\mathrm{C}_{2}\right), 3.68-3.59\left(4 \mathrm{H}, \mathrm{m}, \mathrm{N}-\underline{\mathrm{C}}_{4}\right)$. Incorporation expected at $\delta 3.68-3.59$.

Determined against integral at $\delta$ 7.28-7.18.

\section{LCMS data}

Retention time: $0.49 \mathrm{~min}$; Mass ion: $215.1(\mathrm{M}+\mathrm{H})^{+}$

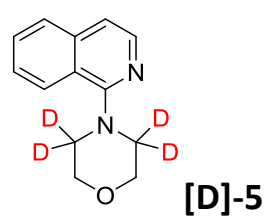

\section{${ }^{1} \mathrm{H}$ NMR data ${ }^{7}$}

${ }^{1}{ }^{H}$ NMR (300 MHz, DMSO-d $\left.\mathrm{d}_{6}\right): \delta$ 8.15-8.08 $(2 \mathrm{H}, \mathrm{m}, \mathrm{Ar}-\underline{\mathrm{H}}), 7.88(1 \mathrm{H}, \mathrm{d}, J=8.2 \mathrm{~Hz}$,

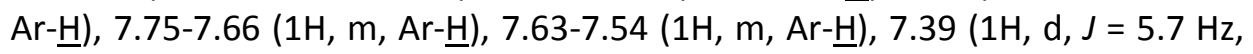
$\operatorname{Ar}-\underline{\mathrm{H}})$, 3.90-3.80 (4H, m, O- $\left.\underline{\mathrm{H}}_{2}\right), 3.33-3.27\left(4 \mathrm{H}, \mathrm{m}, \mathrm{N}-\mathrm{C}_{2} 2\right)$. Incorporation expected at $\delta 3.33-3.27$. Determined against integral at $\delta 7.39$.

\section{LCMS data}

Retention time: $0.80 \mathrm{~min}$; Mass ion: $215.1(\mathrm{M}+\mathrm{H})^{+}$

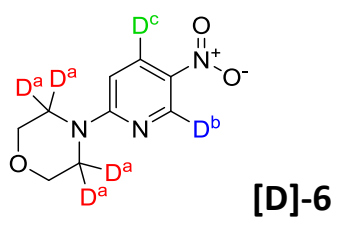

\section{${ }^{1} \mathrm{H} N M R$ data ${ }^{8}$}

${ }^{1} \mathrm{H}$ NMR $\left(300 \mathrm{MHz}, \mathrm{DMSO}-\mathrm{d}_{6}\right): \delta 8.96\left(1 \mathrm{H}, \mathrm{d},{ }^{4} \mathrm{~J}=2.8 \mathrm{~Hz}, \mathrm{Ar}-\underline{\mathrm{H}}\right), 8.23(1 \mathrm{H}, \mathrm{dd}, J=$ $\left.9.6 \mathrm{~Hz},{ }^{4} J=2.8 \mathrm{~Hz}, \mathrm{Ar}-\underline{\mathrm{H}}\right), 6.93(1 \mathrm{H}, \mathrm{d}, J=9.6 \mathrm{~Hz}, \mathrm{Ar}-\underline{\mathrm{H}}), 3.81-3.59\left(8 \mathrm{H}, \mathrm{m}, \mathrm{C}_{2} \underline{2}\right)$. Incorporation expected at $\delta D^{\mathrm{a}} 3.81-3.59, D^{\mathrm{b}} 8.96, D^{\mathrm{c}} 8.23$.

Determined against integral at $\delta 6.93$.

\section{LCMS data}

Retention time: $2.38 \mathrm{~min}$; Mass ion: $210.1(\mathrm{M}+\mathrm{H})^{+}$ 


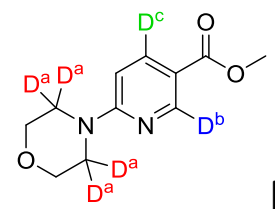

[D]-7
${ }^{1} \mathrm{H}$ NMR $\left(300 \mathrm{MHz}, \mathrm{DMSO}-\mathrm{d}_{6}\right): \delta 8.65\left(1 \mathrm{H}, \mathrm{d},{ }^{4} J=2.5 \mathrm{~Hz}, \mathrm{Ar}-\underline{\mathrm{H}}\right), 7.96(1 \mathrm{H}, \mathrm{dd}, J=$ $\left.9.1 \mathrm{~Hz},{ }^{4} J=2.4 \mathrm{~Hz}, \mathrm{Ar}-\underline{\mathrm{H}}\right), 6.87(1 \mathrm{H}, \mathrm{d}, J=9.2 \mathrm{~Hz}, \mathrm{Ar}-\underline{\mathrm{H}}), 3.78\left(3 \mathrm{H}, \mathrm{s}, \mathrm{O}-\mathrm{C}_{3}\right)$, 3.71-3.64 (4H, m, O- $\left.\underline{\mathrm{C}}_{2}\right), 3.63-3.56\left(4 \mathrm{H}, \mathrm{m}, \mathrm{N}-\mathrm{CH}_{2}\right)$. Incorporation expected at $\delta D^{\mathrm{a}} 3.63-3.56, \mathrm{D}^{\mathrm{b}} 8.65, \mathrm{D}^{\mathrm{c}} 7.96$.

Determined against integral at $\delta 3.78$.

\section{LCMS data}

Retention time: $2.00 \mathrm{~min}$; Mass ion: $223.2(\mathrm{M}+\mathrm{H})^{+}$

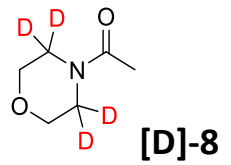

[D]-8

\section{${ }^{1} \mathrm{H}$ NMR data $^{10}$}

${ }^{1} \mathrm{H}$ NMR $\left(300 \mathrm{MHz}, \mathrm{DMSO}-\mathrm{d}_{6}\right): \delta$ 3.59-3.48 (4H, m, O-C $\left.\underline{\mathrm{H}}_{2}\right), 3.45-3.36(4 \mathrm{H}, \mathrm{m}, \mathrm{N}-$ $\left.\mathrm{C}_{2}\right), 1.97\left(3 \mathrm{H}, \mathrm{s}, \mathrm{CO}-\mathrm{C}_{3}\right)$.

Incorporation expected at $\delta 3.45-3.36$.

Determined against integral at $\delta 1.97$.

\section{LCMS dato}

Retention time: $0.41 \mathrm{~min}$; Mass ion: $130.1(\mathrm{M}+\mathrm{H})^{+}$

\section{${ }^{1} \mathrm{H}$ NMR data $^{11}$}

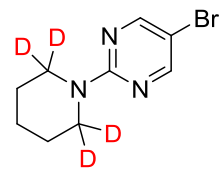

[D]-9
${ }^{1} \mathrm{H}$ NMR (300 MHz, DMSO-d $\left.\mathrm{d}_{6}\right): \delta 8.38(2 \mathrm{H}, \mathrm{br} \mathrm{s}, \mathrm{Ar}-\underline{\mathrm{H}}), 3.75-3.62\left(4 \mathrm{H}, \mathrm{m}, \mathrm{N}-\mathrm{C}_{2}\right)$, 1.66-1.56 (2H, m, $\left.\underline{\mathrm{C}}_{2}\right), 1.55-1.43\left(4 \mathrm{H}, \mathrm{m}, \mathrm{C}_{2}\right)$. Incorporation expected at $\delta 3.75-3.62$.

Determined against integral at $\delta$ 1.55-1.43.

\section{LCMS data}

Retention time: $3.54 \mathrm{~min}$; Mass ion: $242.1(\mathrm{M}+\mathrm{H})^{+}$[using ${ }^{79} \mathrm{Br}$ ]

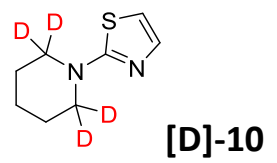

[D]-10

\section{${ }^{1} \mathrm{H}$ NMR data $^{12}$}

${ }^{1} \mathrm{H}$ NMR (300 MHz, DMSO-d $\left.\mathrm{d}_{6}\right): \delta 7.11(1 \mathrm{H}, \mathrm{d}, J=3.7 \mathrm{~Hz}, \mathrm{Ar}-\underline{\mathrm{H}}), 6.75(1 \mathrm{H}, \mathrm{d}, J=$ 3.6 Hz, Ar- $\underline{\mathrm{H}}), 3.45-3.33\left(4 \mathrm{H}, \mathrm{m}, \mathrm{N}-\mathrm{C}_{2}\right)$ ), 1.65-1.52 (6H, m, $\left.\underline{\mathrm{CH}}_{2}\right)$. Incorporation expected at $\delta 3.45-3.33$.

Determined against integral at $\delta 1.65-1.52$.

\section{LCMS data}

Retention time: $0.67 \mathrm{~min}$; Mass ion: $169.0(\mathrm{M}+\mathrm{H})^{+}$

\section{${ }^{1} \mathrm{H}$ NMR data $^{13}$}

${ }^{1} \mathrm{H}$ NMR $\left(300 \mathrm{MHz}, \mathrm{DMSO}-\mathrm{d}_{6}\right): \delta 8.31(2 \mathrm{H}, \mathrm{d}, J=4.7 \mathrm{~Hz}, \operatorname{Ar}-\underline{\mathrm{H}}), 6.55(1 \mathrm{H}, \mathrm{t}, J=4.7$ $\mathrm{Hz}, \operatorname{Ar}-\underline{\mathrm{H}}), 4.64(1 \mathrm{H}, \mathrm{d}, J=4.2 \mathrm{~Hz}, \mathrm{O}-\underline{\mathrm{H}}), 4.24\left(2 \mathrm{H}, \mathrm{ddd},{ }^{2} J=13.0 \mathrm{~Hz}, J=5.6 \mathrm{~Hz}, 4.1\right.$ $\left.\mathrm{Hz}, \mathrm{N}-\underline{\mathrm{C}}_{2}\right), 3.72(1 \mathrm{H}, \mathrm{oct}, J=4.2 \mathrm{~Hz}, \mathrm{O}-\mathrm{CH}), 3.24\left(2 \mathrm{H}, \mathrm{ddd},{ }^{2} J=13.0 \mathrm{~Hz}, J=9.1\right.$ $\left.\mathrm{Hz}, 3.7 \mathrm{~Hz}, \mathrm{~N}-\mathrm{C}_{2}\right), 1.81-1.70\left(2 \mathrm{H}, \mathrm{m}, \mathrm{C}_{2}\right), 1.39-1.23\left(2 \mathrm{H}, \mathrm{m}, \mathrm{C}_{2}\right)$. Incorporation expected at $\delta 3.24$ axial, 4.24 equatorial.

Determined against integral at $\delta$ 1.39-1.23.

\section{LCMS data}

Retention time: $0.72 \mathrm{~min}$; Mass ion: $180.1(\mathrm{M}+\mathrm{H})^{+}$ 


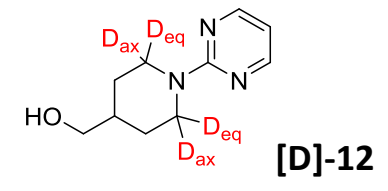

${ }^{1} \mathrm{H}$ NMR (300 MHz, DMSO- $\left.\mathrm{d}_{6}\right): \delta 8.30(2 \mathrm{H}, \mathrm{d}, J=4.7 \mathrm{~Hz}, \mathrm{Ar}-\underline{\mathrm{H}}), 6.53(1 \mathrm{H}, \mathrm{t}, J=4.7$ $\mathrm{Hz}, \mathrm{Ar}-\underline{\mathrm{H}}), 4.70-4.58\left(2 \mathrm{H}, \mathrm{m}, \mathrm{N}-\underline{\mathrm{C}}_{2}\right), 4.40(1 \mathrm{H}, \mathrm{t}, J=5.3 \mathrm{~Hz}, \mathrm{O}-\underline{\mathrm{H}}), 3.33-3.20(2 \mathrm{H}$, $\left.\mathrm{m}, \mathrm{O}-\underline{\mathrm{C}}_{2}\right), 2.83\left(2 \mathrm{H}, \mathrm{td}, \mathrm{J}=12.7 \mathrm{~Hz}, 2.7 \mathrm{~Hz}, \mathrm{~N}-\underline{\mathrm{CH}}_{2}\right), 1.77-1.55\left(3 \mathrm{H}, \mathrm{m}, \mathrm{CH}_{2}-\underline{\mathrm{CH}}\right.$ \& $\left.\mathrm{CH}_{2}\right), 1.14-0.95\left(2 \mathrm{H}, \mathrm{m}, \mathrm{CH}_{2}\right)$.

Incorporation expected at $\delta 2.83$ axial, $4.70-4.58$ equatorial.

Determined against integral at $\delta 1.14-0.95$.

\section{LCMS data}

Retention time: $0.71 \mathrm{~min}$; Mass ion: $194.1(\mathrm{M}+\mathrm{H})^{+}$

\section{${ }^{1} \mathrm{H}$ NMR data $^{15}$}

${ }^{1} \mathrm{H}$ NMR $\left(300 \mathrm{MHz}, \mathrm{DMSO}-\mathrm{d}_{6}\right): \delta 12.15(1 \mathrm{H}, \mathrm{br} \mathrm{s}, \mathrm{O}-\underline{\mathrm{H}}), 8.08\left(1 \mathrm{H}, \mathrm{dd}, J=5.2 \mathrm{~Hz},{ }^{4} \mathrm{~J}\right.$ $=2.0 \mathrm{~Hz}, \mathrm{Ar}-\underline{\mathrm{H}}), 7.49\left(1 \mathrm{H}, \mathrm{ddd}, J=8.7 \mathrm{~Hz}, 7.1 \mathrm{~Hz},{ }^{4} J=2.0 \mathrm{~Hz}, \mathrm{Ar}-\underline{\mathrm{H}}\right), 6.80(1 \mathrm{H}, \mathrm{d}, J$ $=8.7 \mathrm{~Hz}, \mathrm{Ar}-\underline{\mathrm{H}}), 6.58(1 \mathrm{H}, \mathrm{dd}, J=7.1 \mathrm{~Hz}, 5.2 \mathrm{~Hz}, \mathrm{Ar}-\underline{\mathrm{H}}), 4.16\left(2 \mathrm{H}, \mathrm{ddd},{ }^{2} J=13.3\right.$ $\left.\mathrm{Hz}, J=4.3 \mathrm{~Hz}, 3.2 \mathrm{~Hz}, \mathrm{~N}-\mathrm{CH}_{2}\right), 2.92\left(2 \mathrm{H}, \mathrm{ddd},{ }^{2} J=13.3 \mathrm{~Hz}, J=11.5 \mathrm{~Hz}, 2.9 \mathrm{~Hz}, \mathrm{~N}-\right.$

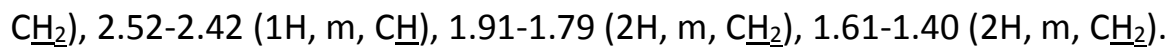
Incorporation expected at $\delta 2.92$ axial, 4.16 equatorial.

Determined against integral at $\delta 1.61-1.40$.

\section{LCMS data}

Retention time: 0.39 min; Mass ion: $207.1(\mathrm{M}+\mathrm{H})^{+}$

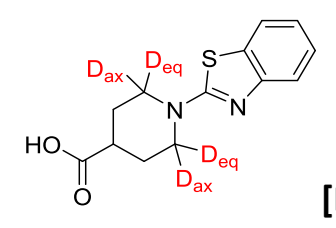

[D]-14

\section{${ }^{1} \mathrm{H}$ NMR data $^{16}$}

${ }^{1} \mathrm{H}$ NMR $\left(300 \mathrm{MHz}, \mathrm{CD}_{3} \mathrm{CN}\right): \delta 9.05(1 \mathrm{H}, \mathrm{br}-\mathrm{s}, \mathrm{O}-\underline{\mathrm{H}}), 7.68\left(1 \mathrm{H}, \mathrm{d}, J=7.5 \mathrm{~Hz},{ }^{4} \mathrm{~J}=\right.$ $1.5 \mathrm{~Hz}, \mathrm{Ar}-\underline{\mathrm{H}}), 7.44(1 \mathrm{H}, \mathrm{d}, J=7.5 \mathrm{~Hz}, \mathrm{Ar}-\underline{\mathrm{H}}), 7.28\left(1 \mathrm{H}, \mathrm{td}, J=7.5 \mathrm{~Hz},{ }^{4} J=1.5 \mathrm{~Hz}\right.$, $\operatorname{Ar}-\underline{H}), 7.07\left(1 \mathrm{H}, \mathrm{td}, J=7.5 \mathrm{~Hz},{ }^{4} J=1.5 \mathrm{~Hz}, \operatorname{Ar}-\underline{\mathrm{H}}\right), 4.04\left(2 \mathrm{H}, \mathrm{ddd},{ }^{2} J=12.6 \mathrm{~Hz}, J\right.$ $\left.=4.2 \mathrm{~Hz}, 4.1 \mathrm{~Hz}, \mathrm{~N}-\mathrm{C}_{2}\right), 3.25\left(2 \mathrm{H}, \mathrm{ddd},{ }^{2} J=12.6 \mathrm{~Hz}, J=11.4 \mathrm{~Hz}, 3.0 \mathrm{~Hz}, \mathrm{~N}-\right.$ $\left.\mathrm{C}_{2} 2\right), 2.62(1 \mathrm{H}, \mathrm{tt}, J=11.1 \mathrm{~Hz}, 4.0 \mathrm{~Hz}, \mathrm{C} \underline{\mathrm{H}}), 2.07-1.96\left(2 \mathrm{H}, \mathrm{m}, \mathrm{C}_{2} \underline{2}\right), 1.81-1.64$ $\left(2 \mathrm{H}, \mathrm{m}, \mathrm{CH}_{2}\right)$.

Incorporation expected at $\delta$ axial 3.25, equatorial 4.04.

Determined against integral at $\delta$ 1.81-1.64.

\section{LCMS data}

Retention time: $2.49 \mathrm{~min}$; Mass ion: $263.1(\mathrm{M}+\mathrm{H})^{+}$

\section{${ }^{1} \mathrm{H}$ NMR data $^{17}$}

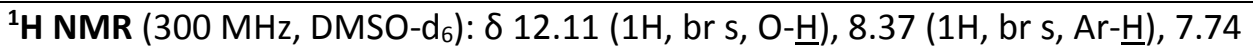<smiles>[2H]C1([2H])CC(C(=O)O)C(O)(O)C(O)(O)N1c1ccc(C(F)(F)F)cn1</smiles>

[D]-15 $\left(1 \mathrm{H}, \mathrm{dd}, J=9.1 \mathrm{~Hz},{ }^{4} J=2.6 \mathrm{~Hz}, \operatorname{Ar}-\underline{\mathrm{H}}\right), 6.93(1 \mathrm{H}, \mathrm{d}, J=9.1 \mathrm{~Hz}, \operatorname{Ar}-\underline{\mathrm{H}}), 4.27(2 \mathrm{H}$, ddd, $\left.{ }^{2} J=13.5 \mathrm{~Hz}, J=3.8 \mathrm{~Hz}, 3.8 \mathrm{~Hz}, \mathrm{~N}-\mathrm{CH}_{2}\right), 3.08\left(2 \mathrm{H}, \mathrm{ddd},{ }^{2} J=13.5 \mathrm{~Hz}, J=11.2\right.$ $\left.\mathrm{Hz}, 3.0 \mathrm{~Hz}, \mathrm{~N}-\mathrm{C}_{2} \underline{2}\right), 2.56(1 \mathrm{H}, \mathrm{tt}, J=11.0 \mathrm{~Hz}, 4.0 \mathrm{~Hz}, \underline{\mathrm{CH}}), 1.94-1.81\left(2 \mathrm{H}, \mathrm{m}, \mathrm{C}_{2}\right)$, 1.61-1.41 (2H, m, $\left.\mathrm{CH}_{2}\right)$.

Incorporation expected at $\delta 3.08$ axial, 4.27 equatorial. Determined against integral at $\delta 1.61-1.41$.

\section{LCMS data}

Retention time: 3.19 min; Mass ion: $275.1(\mathrm{M}+\mathrm{H})^{+}$ 


\section{${ }^{1} \mathrm{H}$ NMR data $^{18}$}

${ }^{1} \mathrm{H}$ NMR $\left(300 \mathrm{MHz}, \mathrm{DMSO}-\mathrm{d}_{6}\right): \delta 8.08\left(1 \mathrm{H}, \mathrm{dd}, J=4.9 \mathrm{~Hz},{ }^{4} J=2.1 \mathrm{~Hz}, \mathrm{Ar}-\underline{\mathrm{H}}\right), 7.49$ $\left(1 \mathrm{H}, \mathrm{ddd}, J=8.7 \mathrm{~Hz}, 7.1 \mathrm{~Hz},{ }^{4} J=2.1 \mathrm{~Hz}, \operatorname{Ar}-\underline{H}\right), 6.75(1 \mathrm{H}, \mathrm{d}, J=8.7 \mathrm{~Hz}, \operatorname{Ar}-\underline{H}), 6.59$ $(1 \mathrm{H}, \mathrm{dd}, J=7.1 \mathrm{~Hz}, 4.9 \mathrm{~Hz}, \mathrm{Ar}-\underline{\mathrm{H}}), 3.43-3.32\left(4 \mathrm{H}, \mathrm{m}, \mathrm{N}-\mathrm{C}_{2}\right), 2.81-2.70(4 \mathrm{H}, \mathrm{m}$, $\left.\mathrm{NH}-\underline{\mathrm{C}}_{2}\right)$.

Incorporation expected at $\delta 3.43-3.32$.

Determined against integral at $\delta$ 2.81-2.70.

\section{LCMS data}

Retention time: $0.37 \mathrm{~min}$; Mass ion: $164.0(\mathrm{M}+\mathrm{H})^{+}$

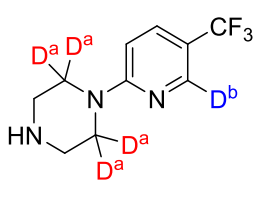

[D]-17

\section{${ }^{1} \mathrm{H}$ NMR data $^{19}$}

${ }^{1} \mathrm{H}$ NMR (300 MHz, DMSO-d $\left.\mathrm{d}_{6}\right): \delta 8.37(1 \mathrm{H}, \mathrm{br} \mathrm{s}, \mathrm{Ar}-\underline{\mathrm{H}}), 7.73\left(1 \mathrm{H}, \mathrm{dd}, J=9.1 \mathrm{~Hz},{ }^{4} \mathrm{~J}=\right.$ $2.7 \mathrm{~Hz}, \mathrm{Ar}-\underline{\mathrm{H}}), 6.88(1 \mathrm{H}, \mathrm{d}, J=9.1 \mathrm{~Hz}, \mathrm{Ar}-\underline{\mathrm{H}}), 3.59-3.48\left(4 \mathrm{H}, \mathrm{m}, \mathrm{N}-\mathrm{CH}_{2}\right), 2.88-2.60(4 \mathrm{H}$, $\left.\mathrm{m}, \mathrm{NH}-\mathrm{CH}_{2}\right)$.

Incorporation expected at $\delta D^{\mathrm{a}} 3.59-3.48, \mathrm{D}^{\mathrm{b}} 8.37$.

Determined against integral at $\delta$ 2.88-2.60.

\section{LCMS data}

Retention time: $1.12 \mathrm{~min}$; Mass ion: $232.3(\mathrm{M}+\mathrm{H})^{+}$

\section{${ }^{1} \mathrm{H}$ NMR data $^{20}$}

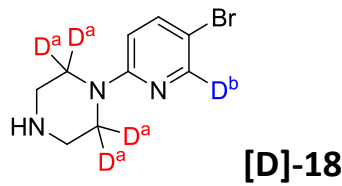

[D]-18
${ }^{1}$ H NMR (300 MHz, DMSO-d 6 ): $\delta 8.40(1 \mathrm{H}, \mathrm{br} \mathrm{s}, \mathrm{Ar}-\mathrm{H}), 7.77\left(1 \mathrm{H}, \mathrm{dd}, J=9.2 \mathrm{~Hz},{ }^{4} \mathrm{~J}=\right.$ $2.5 \mathrm{~Hz}, \mathrm{Ar}-\underline{\mathrm{H}}), 6.92(1 \mathrm{H}, \mathrm{d}, J=9.4 \mathrm{~Hz}, \mathrm{Ar}-\underline{\mathrm{H}}), 3.64-3.46\left(4 \mathrm{H}, \mathrm{m}, \mathrm{N}-\mathrm{C}_{2}\right)$ ), 2.88-2.71 (4H, $\left.\mathrm{m}, \mathrm{NH}-\mathrm{CH}_{2}\right)$.

Incorporation expected at $\delta D^{a} 3.64-3.46, D^{b} 8.40$.

Determined against integral at $\delta 2.88-2.71$.

Retention time: 2.24 min; Mass ion: $242.1(\mathrm{M}+\mathrm{H})^{+}$[using ${ }^{79} \mathrm{Br}$ ]

\section{${ }^{1} \mathrm{H}$ NMR data $^{21}$}

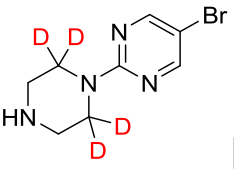

[D]-19
${ }^{1} \mathrm{H}$ NMR $\left(300 \mathrm{MHz}, \mathrm{DMSO}-\mathrm{d}_{6}\right): 8.46(2 \mathrm{H}, \mathrm{br} \mathrm{s}, \mathrm{Ar}-\underline{\mathrm{H}}), 3.89-3.75\left(4 \mathrm{H}, \mathrm{m}, \mathrm{N}-\underline{\mathrm{C}}_{2}\right)$, 2.90-2.78 (4H, m, NH-Cㅡㄹ 2$)$.

Incorporation expected at $\delta 3.89-3.75$.

Determined against integral at $\delta$ 2.90-2.78.

\section{LCMS data}

Retention time: 2.24 min; Mass ion: $243.1(\mathrm{M}+\mathrm{H})^{+}$[using ${ }^{79} \mathrm{Br}$ ]

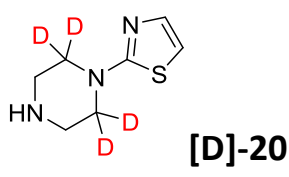

\section{${ }^{1} \mathrm{H}$ NMR data $^{22}$}

${ }^{1} \mathrm{H}$ NMR $\left(300 \mathrm{MHz}, \mathrm{DMSO}-\mathrm{d}_{6}\right): \delta 7.14(1 \mathrm{H}, \mathrm{d}, J=3.6 \mathrm{~Hz}, \mathrm{Ar}-\underline{\mathrm{H}}), 6.79(1 \mathrm{H}, \mathrm{d}, J=3.6$

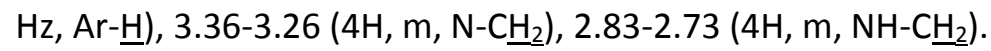

Incorporation expected at $\delta 3.36-3.26$.

Determined against integral at $\delta$ 2.83-2.73.

\section{LCMS data}

Retention time: $0.29 \mathrm{~min}$; Mass ion: $170.1(\mathrm{M}+\mathrm{H})^{+}$ 


\section{${ }^{1} \mathrm{H}$ NMR data ${ }^{23}$}

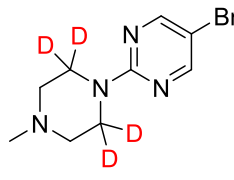

[D]-21

${ }^{1} \mathrm{H}$ NMR $\left(300 \mathrm{MHz}, \mathrm{DMSO}-\mathrm{d}_{6}\right): \delta 8.42(2 \mathrm{H}, \mathrm{s}, \mathrm{Ar}-\underline{\mathrm{H}}), 3.76-3.63\left(4 \mathrm{H}, \mathrm{m}, \mathrm{N}-\underline{\mathrm{C}}_{2}\right), 2.38-$ $2.29\left(4 \mathrm{H}, \mathrm{m}, \mathrm{NMe}-\mathrm{C}_{2}\right), 2.19\left(3 \mathrm{H}, \mathrm{s}, \mathrm{N}-\mathrm{C}_{3}\right)$.

Incorporation expected at $\delta 3.76-3.63$.

Determined against integral at $\delta 2.19$.

LCMS data

Retention time: $0.41 \mathrm{~min}$; Mass ion: $257.1(\mathrm{M}+\mathrm{H})^{+}$[using ${ }^{79} \mathrm{Br}$ ]

\section{${ }^{1} \mathrm{H}$ NMR data $^{24}$}

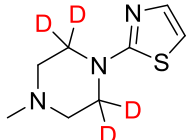

[D]-22
${ }^{1} \mathbf{H}$ NMR $\left(300 \mathrm{MHz}\right.$, DMSO- $\left.\mathrm{d}_{6}\right): \delta 7.15(1 \mathrm{H}, \mathrm{d}, J=3.6 \mathrm{~Hz}, \mathrm{Ar}-\underline{\mathrm{H}}), 6.81(1 \mathrm{H}, \mathrm{d}, J=3.6 \mathrm{~Hz}, \mathrm{Ar}-$ $\underline{\mathrm{H}}), 3.43-3.33\left(4 \mathrm{H}, \mathrm{m} \mathrm{N}-\underline{\mathrm{H}}_{2}\right), 2.46-2.35\left(4 \mathrm{H}, \mathrm{m}, \mathrm{NMe}-\mathrm{C}_{2}\right), 2.21\left(3 \mathrm{H}, \mathrm{s}, \mathrm{N}-\underline{\mathrm{C}}_{3}\right)$. Incorporation expected at $\delta 3.43-3.33$.

Determined against integral at $\delta 2.21$.

\section{LCMS data}

Retention time: $0.29 \mathrm{~min}$; Mass ion: $184.1(\mathrm{M}+\mathrm{H})^{+}$

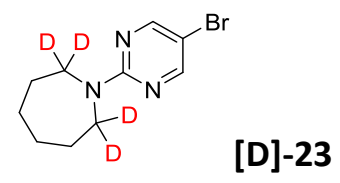

[D]-24

${ }^{1} \mathrm{H}$ NMR $\left(300 \mathrm{MHz}, \mathrm{DMSO}-\mathrm{d}_{6}\right)$ : $\delta 8.39(2 \mathrm{H}, \mathrm{br} \mathrm{s}, \mathrm{Ar}-\underline{\mathrm{H}}), 3.73-3.60\left(4 \mathrm{H}, \mathrm{m}, \mathrm{N}-\underline{\mathrm{C}}_{2}\right)$ ), 1.77-1.61 (4H, m, $\left.\mathrm{C}_{2}\right), 1.54-1.39\left(4 \mathrm{H}, \mathrm{m}, \mathrm{CH}_{2}\right)$. Incorporation expected at $\delta 3.73-3.60$. Determined against integral at $\delta$ 1.54-1.39.

\section{LCMS data}

Retention time: $0.29 \mathrm{~min}$; Mass ion: $256.1(\mathrm{M}+\mathrm{H})^{+}$[using ${ }^{79} \mathrm{Br}$ ]

\section{${ }^{1} \mathrm{H}$ NMR data $^{26}$}

${ }^{1} \mathrm{H}$ NMR (300 MHz, DMSO-d $\left.\mathrm{d}_{6}\right): \delta 8.40(2 \mathrm{H}, \mathrm{br} \mathrm{s}, \mathrm{Ar}-\underline{\mathrm{H}}), 3.53-3.38\left(4 \mathrm{H}, \mathrm{m}, \mathrm{N}-\mathrm{C}_{2}\right)$, 2.01-1.85 (4H, m, $\left.\mathrm{CH}_{2}\right)$.

Incorporation expected at $\delta 3.53-3.38$.

Determined against integral at $\delta$ 2.01-1.85.

\section{LCMS data}

Retention time: 2.85 min; Mass ion: $228.1(\mathrm{M}+\mathrm{H})^{+}$[using ${ }^{79} \mathrm{Br}$ ]

\section{${ }^{1} \mathrm{H}$ NMR data $^{27}$}

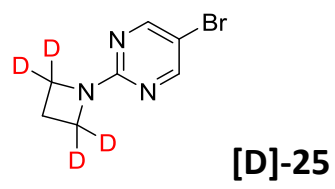

${ }^{1} \mathrm{H}$ NMR $\left(300 \mathrm{MHz}, \mathrm{DMSO}-\mathrm{d}_{6}\right): \delta 8.40(2 \mathrm{H}, \mathrm{br} \mathrm{s}, \mathrm{Ar}-\underline{\mathrm{H}}), 4.02\left(4 \mathrm{H}, \mathrm{t}, J=7.5 \mathrm{~Hz}, \mathrm{~N}-\mathrm{CH}_{2}\right)$, $2.30\left(2 \mathrm{H}\right.$, quin, $\left.J=7.6 \mathrm{~Hz}, \mathrm{CH}_{2}\right)$.

Incorporation expected at $\delta \mathrm{D} 4.02$.

Determined against integral at $\delta 2.30$.

\section{LCMS data}

Retention time: $2.30 \mathrm{~min}$; Mass ion: $214.0(\mathrm{M}+\mathrm{H})^{+}$[using ${ }^{79} \mathrm{Br}$ ]

\section{${ }^{1} \mathrm{H}$ NMR data $^{28}$}

${ }^{1} \mathrm{H}$ NMR (300 MHz, DMSO-d $\left.\mathrm{d}_{6}\right): \delta 8.04\left(1 \mathrm{H}, \mathrm{dd}, J=4.9 \mathrm{~Hz},{ }^{4} J=2.1 \mathrm{~Hz}, \mathrm{Ar}-\underline{\mathrm{H}}\right)$, $7.45\left(1 \mathrm{H}, \mathrm{ddd}, J=8.7 \mathrm{~Hz}, 7.1 \mathrm{~Hz},{ }^{4} J=2.1 \mathrm{~Hz}, \operatorname{Ar}-\underline{\mathrm{H}}\right), 6.57(1 \mathrm{H}, \mathrm{d}, J=8.7 \mathrm{~Hz}, \mathrm{Ar}-$

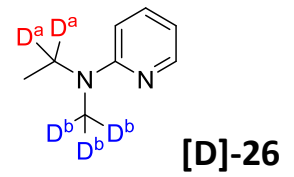
ㅂ) $), 6.50(1 \mathrm{H}, \mathrm{dd}, J=7.1 \mathrm{~Hz}, 4.8 \mathrm{~Hz}, \operatorname{Ar}-\underline{\mathrm{H}}), 3.53\left(2 \mathrm{H}, \mathrm{q}, J=7.1 \mathrm{~Hz}, \mathrm{~N}-\underline{\mathrm{C}}_{2}\right), 2.94$ $\left(3 \mathrm{H}, \mathrm{s}, \mathrm{N}-\mathrm{C}_{3}\right), 1.05\left(3 \mathrm{H}, \mathrm{t}, J=7.1 \mathrm{~Hz}, \mathrm{CH}_{2}-\mathrm{C}_{3}\right)$. Incorporation expected at $\delta D^{\mathrm{a}} 3.53, \mathrm{D}^{\mathrm{b}} 2.94$. Determined against integral at $\delta 1.05$.

\section{LCMS data}

Retention time: $0.30 \mathrm{~min}$; Mass ion: $137.2(\mathrm{M}+\mathrm{H})^{+}$ 
${ }^{1} \mathrm{H}$ NMR $\left(300 \mathrm{MHz}\right.$, DMSO-d $\left.\mathrm{d}_{6}\right): \delta 7.96\left(1 \mathrm{H}, \mathrm{dd}, J=5.0 \mathrm{~Hz},{ }^{4} J=2.0 \mathrm{~Hz}, \mathrm{Ar}-\underline{\mathrm{H}}\right), 7.34$<smiles>[2H]C([2H])([2H])Nc1ccccn1</smiles>
$\left(1 \mathrm{H}, \mathrm{ddd}, J=8.4 \mathrm{~Hz}, 7.0 \mathrm{~Hz},{ }^{4} J=2.0 \mathrm{~Hz}, \mathrm{Ar}-\underline{\mathrm{H}}\right), 6.50-6.37(2 \mathrm{H}, \mathrm{m}, \operatorname{Ar}-\underline{\mathrm{H}}), 6.31(1 \mathrm{H}$, br s, N-ㅡㅏ), $2.75\left(3 \mathrm{H}, \mathrm{d}, J=4.9 \mathrm{~Hz}, \mathrm{NH}-\mathrm{CH}_{3}\right)$. Incorporation expected at $\delta 2.75$.

Determined against integral at $\delta 7.34$.

\section{LCMS data}

Retention time: $0.25 \mathrm{~min}$; Mass ion: $109.2(\mathrm{M}+\mathrm{H})^{+}$

\section{${ }^{1} \mathrm{H}$ NMR data $^{30}$}

${ }^{1} \mathrm{H}$ NMR $\left(300 \mathrm{MHz}, \mathrm{DMSO}-\mathrm{d}_{6}\right): \delta 8.21(1 \mathrm{H}, \mathrm{d}, J=8.9 \mathrm{~Hz}, \mathrm{Ar}-\underline{\mathrm{H}}), 7.86(1 \mathrm{H}, \mathrm{dd}, J=$ $\left.7.8 \mathrm{~Hz},{ }^{4} J=1.6 \mathrm{~Hz}, \mathrm{Ar}-\underline{\mathrm{H}}\right), 7.78(1 \mathrm{H}, \mathrm{d}, J=8.3 \mathrm{~Hz}, \mathrm{Ar}-\underline{\mathrm{H}}), 7.65(1 \mathrm{H}, \mathrm{ddd}, J=8.4 \mathrm{~Hz}$, $\left.7.0 \mathrm{~Hz},{ }^{4} J=1.6 \mathrm{~Hz}, \operatorname{Ar}-\underline{\mathrm{H}}\right), 7.42\left(1 \mathrm{H}, \mathrm{ddd}, J=8.1 \mathrm{~Hz}, 6.9 \mathrm{~Hz},{ }^{4} J=1.4 \mathrm{~Hz}, \operatorname{Ar}-\underline{\mathrm{H}}\right)$, $7.00(1 \mathrm{H}, \mathrm{d} J=8.9 \mathrm{~Hz}, \mathrm{Ar}-\underline{\mathrm{H}}), 3.98\left(3 \mathrm{H}, \mathrm{s}, \mathrm{O}-\mathrm{C}_{3}\right)$. Incorporation expected at $\delta 3.98$.

Determined against integral at $\delta 7.00$.

\section{LCMS data}

Retention time: $3.00 \mathrm{~min}$; Mass ion: $160.1(\mathrm{M}+\mathrm{H})^{+}$

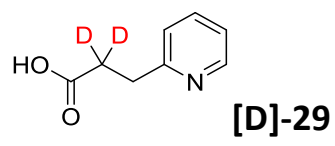

\section{${ }^{1} \mathrm{H}$ NMR data $^{31}$}

${ }^{1} \mathrm{H}$ NMR $\left(300 \mathrm{MHz}, \mathrm{DMSO}-\mathrm{d}_{6}\right): \delta 12.10(1 \mathrm{H}, \mathrm{br} \mathrm{s}, \mathrm{O}-\underline{\mathrm{H}}), 8.46(1 \mathrm{H}, \mathrm{dd}, J=5.1 \mathrm{~Hz}$, $\left.{ }^{4} J=1.9 \mathrm{~Hz}, \operatorname{Ar}-\underline{H}\right), 7.68\left(1 \mathrm{H}, \mathrm{dd}, J=7.7 \mathrm{~Hz},{ }^{4} J=1.9 \mathrm{~Hz}, \operatorname{Ar}-\underline{H}\right), 7.26(1 \mathrm{H}, \mathrm{d}, J=7.9$ $\mathrm{Hz}, \operatorname{Ar}-\underline{\mathrm{H}}), 7.19(1 \mathrm{H}, \mathrm{dd}, J=7.7 \mathrm{~Hz}, 5.0 \mathrm{~Hz}, \mathrm{Ar}-\underline{\mathrm{H}}), 2.96\left(2 \mathrm{H}, \mathrm{t}, J=7.4 \mathrm{~Hz}, \mathrm{Ar}-\mathrm{C}_{2}\right)$, $2.65\left(2 \mathrm{H}, \mathrm{t}, J=7.4 \mathrm{~Hz}, \mathrm{CO}-\mathrm{CH}_{2}\right)$.

Incorporation expected at $\delta 2.65$.

Determined against integral at $\delta 7.68$.

\section{LCMS data}

Retention time: $0.29 \mathrm{~min}$; Mass ion: $152.1(\mathrm{M}+\mathrm{H})^{+}$

\section{${ }^{1} \mathrm{H}$ NMR data $^{32}$}

${ }^{1} \mathrm{H}$ NMR (300 MHz, DMSO-d $\left.\mathrm{d}_{6}\right): \delta 8.45(1 \mathrm{H}, \mathrm{d}, J=4.9 \mathrm{~Hz}, \mathrm{Ar}-\underline{\mathrm{H}}), 7.68(1 \mathrm{H}, \mathrm{td}, J=$ $\left.7.7 \mathrm{~Hz},{ }^{4} J=1.8 \mathrm{~Hz}, \operatorname{Ar}-\underline{\mathrm{H}}\right), 7.26(1 \mathrm{H}, \mathrm{d}, J=7.5 \mathrm{~Hz}, \operatorname{Ar}-\underline{\mathrm{H}}), 7.18(1 \mathrm{H}, \mathrm{dd}, J=7.3 \mathrm{~Hz}$, $\prod_{0}^{D_{[D]-30}}$ $4.8 \mathrm{~Hz}, \operatorname{Ar}-\underline{\mathrm{H}}), 4.02\left(2 \mathrm{H}, \mathrm{q}, J=7.2 \mathrm{~Hz}, \mathrm{O}-\mathrm{C}_{\underline{2}}\right), 2.99\left(2 \mathrm{H}, \mathrm{t}, J=7.3 \mathrm{~Hz}, \mathrm{Ar}-\mathrm{CH}_{2}\right)$, $2.72\left(2 \mathrm{H}, \mathrm{t}, J=7.3 \mathrm{~Hz}, \mathrm{CO}-\mathrm{C}_{2}\right), 1.13\left(3 \mathrm{H}, \mathrm{t}, J=7.2 \mathrm{~Hz}, \mathrm{CH}_{2}-\mathrm{C}_{3}\right)$. Incorporation expected at $\delta D^{\mathrm{a}}: 2.72, \mathrm{D}^{\mathrm{b}}: 8.45$.

Determined against integral at $\delta 1.13$. 


\section{${ }^{1} \mathrm{H}$ NMR data ${ }^{3}$}

${ }^{1} \mathrm{H}$ NMR (300 MHz, DMSO-d 6 ): $\delta 8.08\left(1 \mathrm{H}, \mathrm{dd}, J=4.9 \mathrm{~Hz},{ }^{4} J=1.9 \mathrm{~Hz}, \mathrm{Ar}-\mathrm{H}\right), 7.43$

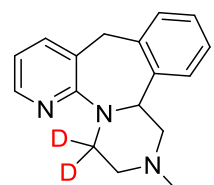
$(1 \mathrm{H}, \mathrm{d}, J=7.3 \mathrm{~Hz}, \operatorname{Ar}-\underline{\mathrm{H}}), 7.30-7.07(4 \mathrm{H}, \mathrm{m}, \mathrm{Ar}-\underline{\mathrm{H}}), 6.77(1 \mathrm{H}, \mathrm{dd}, J=7.3 \mathrm{~Hz}, 4.9 \mathrm{~Hz}$, $\operatorname{Ar}-\underline{H}), 4.39-4.19\left(2 \mathrm{H}, \mathrm{m}, \mathrm{N}-\mathrm{C} \underline{\mathrm{H}} \& \mathrm{Ar}-\mathrm{C}_{2}\right), 3.67\left(1 \mathrm{H}, \mathrm{d},{ }^{2} \mathrm{~J}=13.5 \mathrm{~Hz}, \mathrm{Ar}-\mathrm{C}_{2}\right), 3.48-$ $3.36\left(2 \mathrm{H}, \mathrm{m}, \mathrm{N}-\mathrm{C}_{2}\right), 2.84-2.66\left(2 \mathrm{H}, \mathrm{m}, \mathrm{NMe}-\underline{\mathrm{C}}_{2}\right), 2.52-2.45\left(1 \mathrm{H}, \mathrm{m}, \mathrm{NMe}-\underline{\mathrm{C}}_{2}\right)$, 2.36-2.19 (4H, m, N-C $\left.\underline{H}_{3} \& \mathrm{NMe}-\underline{\mathrm{C}}_{2}\right)$.

[D]-31 Incorporation expected at $\delta$ 3.48-3.36.

Determined against integral at $\delta 3.67$.

\section{LCMS data}

Retention time: $0.50 \mathrm{~min}$; Mass ion: $266.3(\mathrm{M}+\mathrm{H})^{+}$

\section{${ }^{1} \mathrm{H}$ NMR data $^{34}$}

${ }^{1} \mathrm{H}$ NMR $\left(300 \mathrm{MHz}, \mathrm{DMSO}-\mathrm{d}_{6}\right): \delta 8.15-7.91(3 \mathrm{H}, \mathrm{m}, \mathrm{Ar}-\underline{\mathrm{H}}), 7.49$ (1H, ddd, $J=$

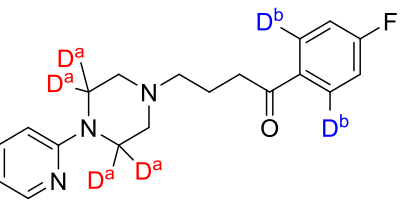
$\left.8.5 \mathrm{~Hz}, 7.7 \mathrm{~Hz},{ }^{4} J=2.2 \mathrm{~Hz}, \operatorname{Ar}-\underline{-} \underline{\mathrm{H}}\right), 7.39-7.24(2 \mathrm{H}, \mathrm{m}, \operatorname{Ar}-\underline{-} \underline{\mathrm{H}}), 6.76(1 \mathrm{H}, \mathrm{d}, J=$ $8.6 \mathrm{~Hz}, \mathrm{Ar}-\underline{\mathrm{H}}), 6.60(1 \mathrm{H}, \mathrm{dd}, J=7.7 \mathrm{~Hz}, 4.8 \mathrm{~Hz}, \mathrm{Ar}-\underline{\mathrm{H}}), 3.43-3.32(4 \mathrm{H}, \mathrm{m}, \mathrm{Ar}-$ $\left.\mathrm{N}-\underline{\mathrm{C}}_{2}\right), 3.01\left(2 \mathrm{H}, \mathrm{t}, J=7.0 \mathrm{~Hz}, \mathrm{~N}-\mathrm{C}_{2}\right), 2.45-2.27\left(6 \mathrm{H}, \mathrm{m}, \mathrm{C}_{2} \underline{\mathrm{H}} \& \mathrm{~N}-\underline{\mathrm{C}}_{2}\right)$, 1.90-1.77 (2H, m, $\left.\mathrm{CH}_{2}\right)$.

[D]-32 Incorporation expected at $\delta D^{\mathrm{a}} 3.43-3.32, D^{\mathrm{b}} 8.15-7.91$.

Determined against integral at $\delta$ 1.90-1.77.

LCMS data

Retention time: 0.38 min; Mass ion: $328.4(\mathrm{M}+\mathrm{H})^{+}$

\section{${ }^{1} \mathrm{H} N \mathrm{NR}$ data $^{35}$}

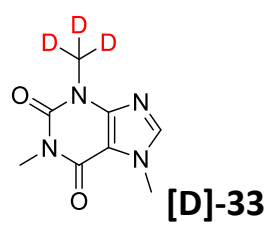

${ }^{1} \mathrm{H}$ NMR $\left(300 \mathrm{MHz}, \mathrm{DMSO}-\mathrm{d}_{6}\right): \delta 7.98(1 \mathrm{H}, \mathrm{s}, \mathrm{Ar}-\underline{\mathrm{H}}), 3.87\left(3 \mathrm{H}, \mathrm{s}, \mathrm{N}-\underline{\mathrm{C}}_{3}\right), 3.40(3 \mathrm{H}$, $\left.\mathrm{s}, \mathrm{N}-\mathrm{C}_{3}\right), 3.21\left(3 \mathrm{H}, \mathrm{s}, \mathrm{N}-\mathrm{C}_{3}\right)$.

Incorporation expected at $\delta 3.40$.

Determined against integral at $\delta 3.87$.

Retention time: $0.92 \mathrm{~min}$; Mass ion: $195.1(\mathrm{M}+\mathrm{H})^{+}$ 


\section{NMR Studies Regarding Piperazine NH Binding}

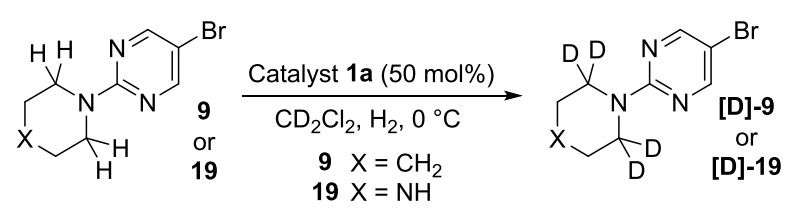

Experiments were run to determine the effect of secondary amines on the unactivated pre-catalyst, and activated catalyst species. Below, "Unactivated" refers to experiments run without catalyst activation with $\mathrm{H}_{2}$, and "Activated" refers to experiments run after catalyst activation with $\mathrm{H}_{2}$.

"Activated" protocol: In an oven dried NMR tube, substrate (9: $4.8 \mathrm{mg}, 0.02 \mathrm{mmol}$ or 19: $4.9 \mathrm{mg}, 0.02 \mathrm{mmol}$ ), catalyst $1 \mathrm{a}(10 \mathrm{mg}, 0.01 \mathrm{mmol})$ and $\mathrm{DCM}(0.5 \mathrm{~mL})$ were added and the tube capped with a rubber septum. Hydrogen was bubbled through the solution at a constant rate for $5 \mathrm{~min}$ to activate the catalyst, and a red to yellow colour change was observed. Following the catalyst activation the NMR tube was cooled to $0{ }^{\circ} \mathrm{C}$ in an ice bath prior to injection into the NMR spectrometer. ${ }^{31} \mathrm{P}$ NMR experiments were run at $0{ }^{\circ} \mathrm{C}$ to allow observation of changes in the active catalytic species.

"Unactivated" protocol: This follows the above "Activated" protocol, but without the introduction of hydrogen gas.

${ }^{31}$ P NMR data for the experiments are displayed below (Fig. S2).

The experiments reveal that when unactivated, the pre-catalyst remains unaffected by the substrate, showing the same shift of $18.3 \mathrm{ppm}$. Similarly, in the case of piperidine-containing substrate 9 a single catalytic species is formed, with a ${ }^{31} \mathrm{P}$ NMR shift of $24.9 \mathrm{ppm}$ after activation. However, with piperazine containing substrate 19, several signals are observed, with none appearing at 24.9 ppm, clearly indicating several different phosphine-containing species are being formed.

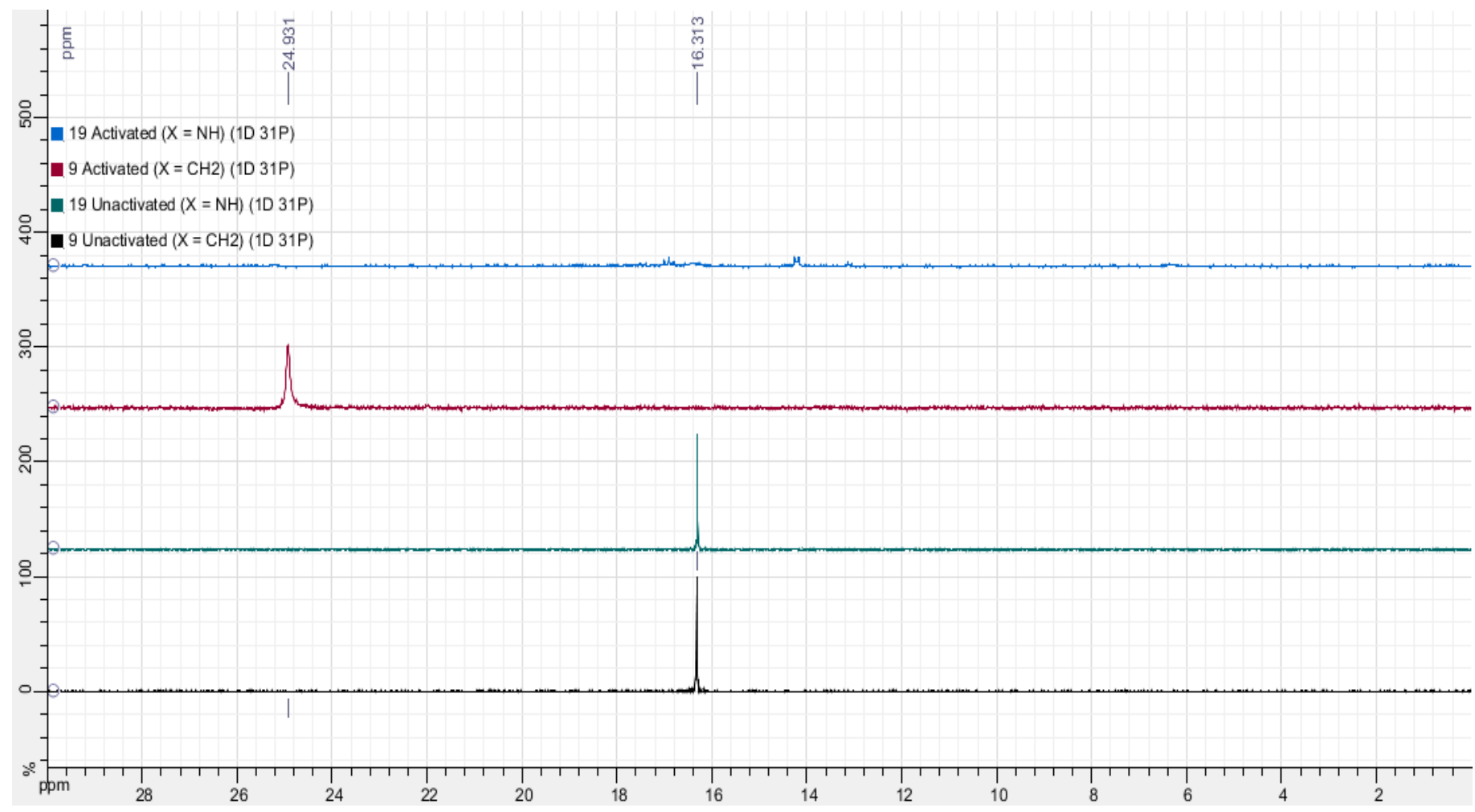

Figure S2. 


\section{Mechanistic Investigations}

\subsection{Mercury Nanoparticle Test}
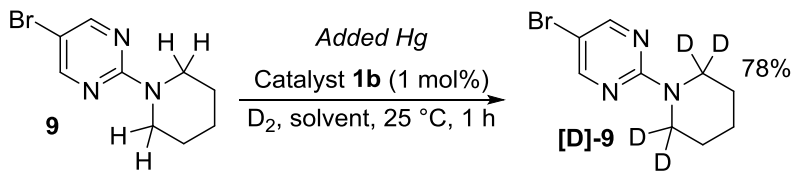

The reaction was carried out as described on page S7, except with the addition of a mercury drop prior to catalyst activation with $D_{2}$. The reaction proceeded to similarly high incorporation (78\%) as without added mercury (91\%), indicating that the reaction is homogeneous in nature, and is not catalysed by heterogeneous nanoparticles formed in situ. 


\subsection{Order of Reaction}

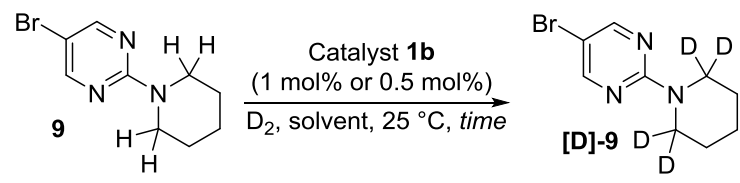

Reactions were carried out following the general procedure on page S7, using 5-bromo-2-(piperidin-1-yl)pyrimidine 9 ( $20.8 \mathrm{mg}, 0.086 \mathrm{mmol}, 1 \mathrm{eq}$ ), with catalyst $1 \mathrm{~b}(1.5 \mathrm{mg}, 0.00086 \mathrm{mmol}, 1.0 \mathrm{~mol} \%$ or $0.7 \mathrm{mg}, 0.00043 \mathrm{mmol}, 0.5 \mathrm{~mol} \%$ ) in $1 \mathrm{~mL}$ of solvent $(0.086 \mathrm{M})$ under an atmosphere of $\mathrm{D}_{2}$ for the stated time at $25{ }^{\circ} \mathrm{C}$. The deuterium incorporation was assigned by ${ }^{1} \mathrm{H}$ NMR spectroscopy. The full incorporation data are given below in Table S6, and in Graph S5.

Table S6. Reactions carried out to determine the order of the reaction with respect to catalyst.

\begin{tabular}{|c|c|c|c|}
\hline Entry & Time (min) & Catalyst Loading (mol\%) & Deuterium Incorporation (\%D) \\
\hline 1 & \multirow{2}{*}{3} & 0.5 & 8 \\
\hline 2 & & 1.0 & 12 \\
\hline 3 & \multirow{2}{*}{5} & 0.5 & 17 \\
\hline 4 & & 1.0 & 32 \\
\hline 5 & \multirow{2}{*}{7} & 0.5 & 23 \\
\hline 6 & & 1.0 & 46 \\
\hline 7 & \multirow{2}{*}{9} & 0.5 & 32 \\
\hline 8 & & 1.0 & 61 \\
\hline 9 & \multirow{2}{*}{11} & 0.5 & 39 \\
\hline 10 & & 1.0 & 67 \\
\hline
\end{tabular}

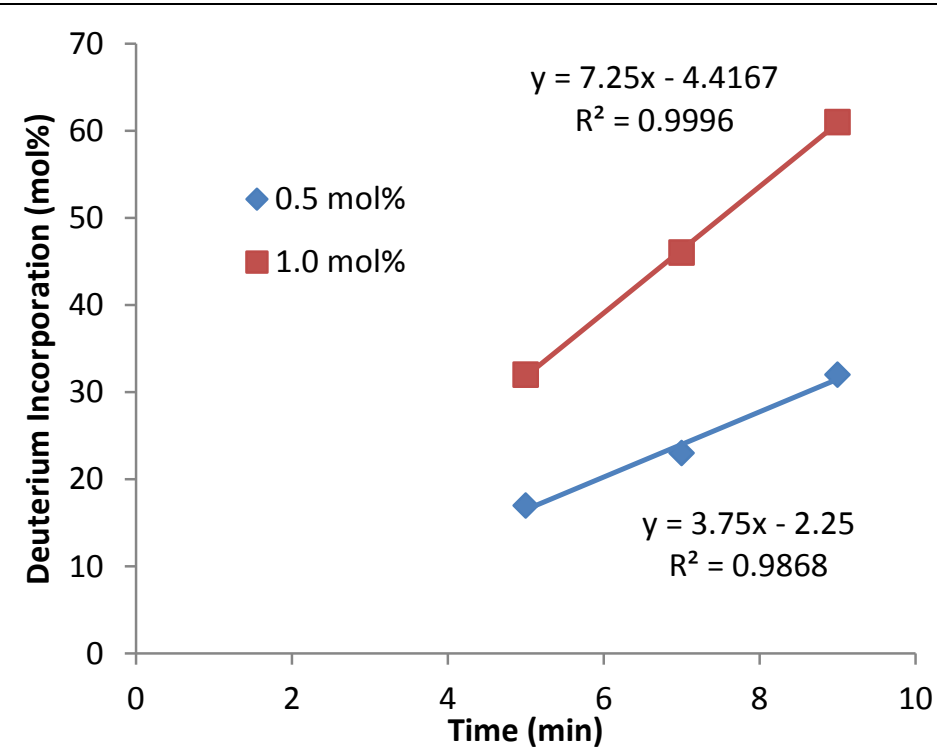

Graph S5. Rate study to determine the order of reaction with respect to catalyst.

The data points for 3 min were discarded as they could occur within the catalyst activation period. The data points for 11 min were discarded as product inhibition has been observed when the incorporation is $>60 \%$.

The gradient of the line is proportional to the reaction rate constant. Therefore, the rate increases by a factor of 1.93 $(1.93 \approx 2)$ in changing the catalyst loading from 0.5 to 1.0 , indicating a first order rate dependence upon the catalyst. 


\subsection{Kinetic Isotope Effect}

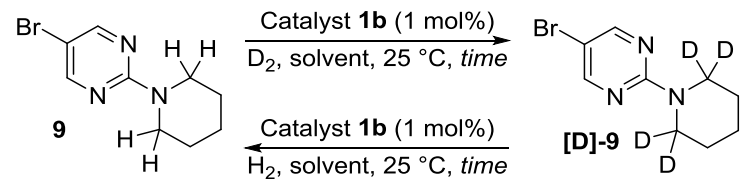

$\mathrm{KIE}=3.22$

Reactions to incorporate deuterium were carried out following the general procedure on page S7, using 5-bromo-2(piperidin-1-yl)pyrimidine 9 (20.8 mg, $0.086 \mathrm{mmol}, 1 \mathrm{eq})$, with catalyst $(0.00086 \mathrm{mmol}, 1.0 \mathrm{~mol} \%)$ in $1 \mathrm{~mL}$ of solvent $(0.086 \mathrm{M})$ under an atmosphere of $\mathrm{D}_{2}$ for the stated time at $25^{\circ} \mathrm{C}$.

Reactions to incorporate hydrogen were carried out following the general procedure on page S7, using 5-bromo-2$\left(2,2^{\prime}, 6,6^{\prime}\right.$ - $\mathrm{d}_{4}$-piperidin-1-yl)pyrimidine [D]-9 $(21.1 \mathrm{mg}, 0.086 \mathrm{mmol}, 1 \mathrm{eq})$, with catalyst $(0.00086 \mathrm{mmol}, 1.0 \mathrm{~mol} \%)$ in 1 $\mathrm{mL}$ of solvent $(0.086 \mathrm{M})$ under an atmosphere of $\mathrm{H}_{2}$ for the stated time at $25^{\circ} \mathrm{C}$.

The deuterium/hydrogen incorporation was assigned by ${ }^{1} \mathrm{H}$ NMR spectroscopy. The full incorporation data are given below in Table S7, and Graph S6.

Table S7. Reactions carried out to determine the kinetic isotope effect.

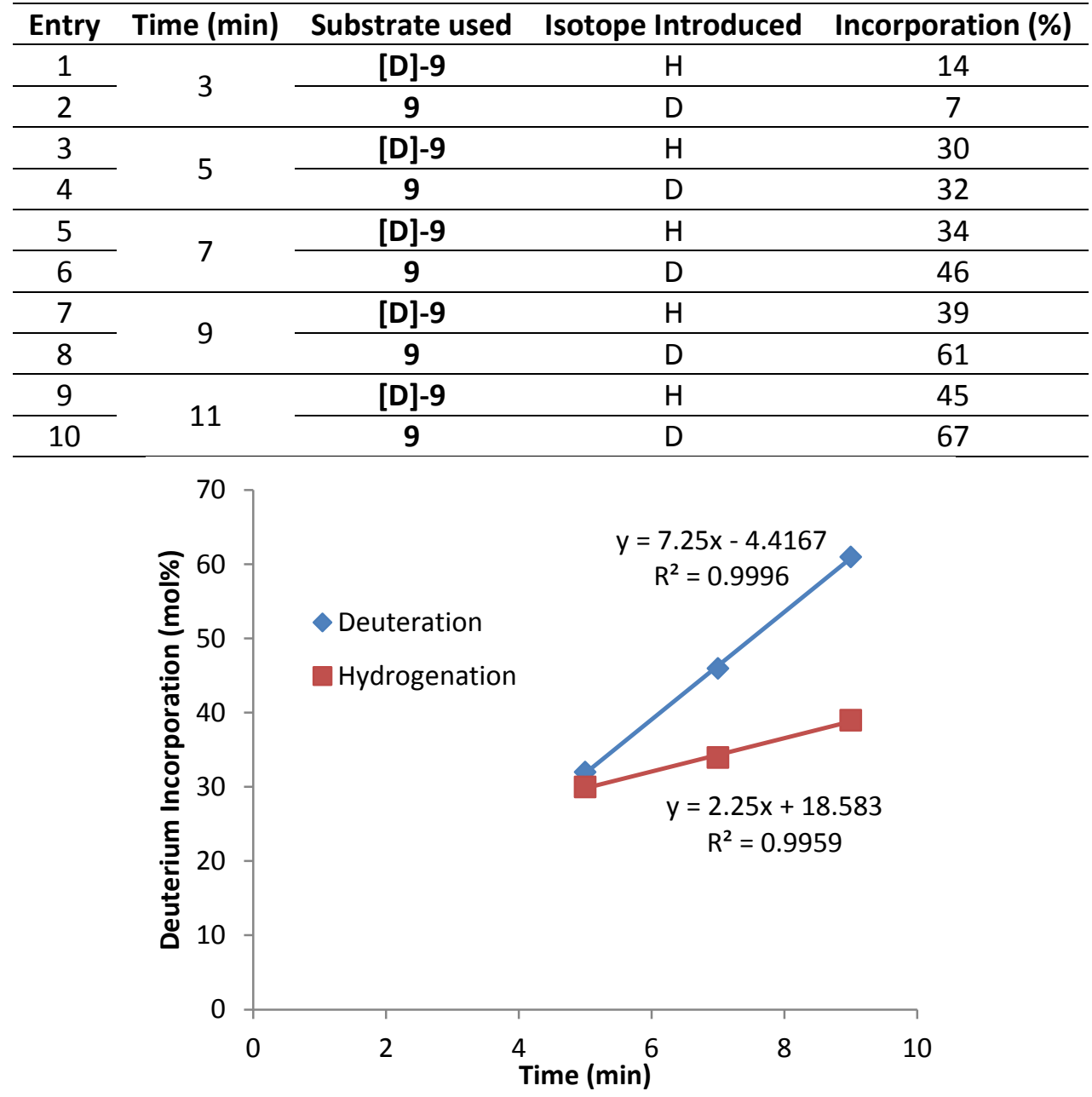

Graph S6. Rate study to determine the kinetic isotope effect.

The data points for $3 \mathrm{~min}$ were discarded as they could occur within the catalyst activation period. The data points for $11 \mathrm{~min}$ were discarded as product inhibition has been observed when the incorporation is $>60 \%$. The gradient of the line is proportional to the reaction rate constant. Therefore, the kinetic isotope effect $\left(k_{H} / k_{D}\right)$ is $(7.25 / 2.25) 3.22$. 


\section{Compound Spectra}

9.1. Catalyst $\left[(\mathrm{COD}) \operatorname{Ir}(\mathrm{IMes})\left(\mathrm{PBn}_{3}\right)\right] \mathrm{BAr} \mathrm{F}^{\mathrm{F}}, 1 \mathrm{C}$.

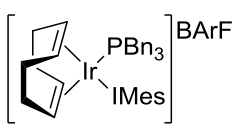

Chemical Formula: $\mathrm{C}_{82} \mathrm{H}_{69} \mathrm{BF}_{24} \mathrm{lrN}{ }_{2} \mathrm{P}$

Molecular Weight: 1772.43

\section{${ }^{1} \mathrm{H}$ NMR}

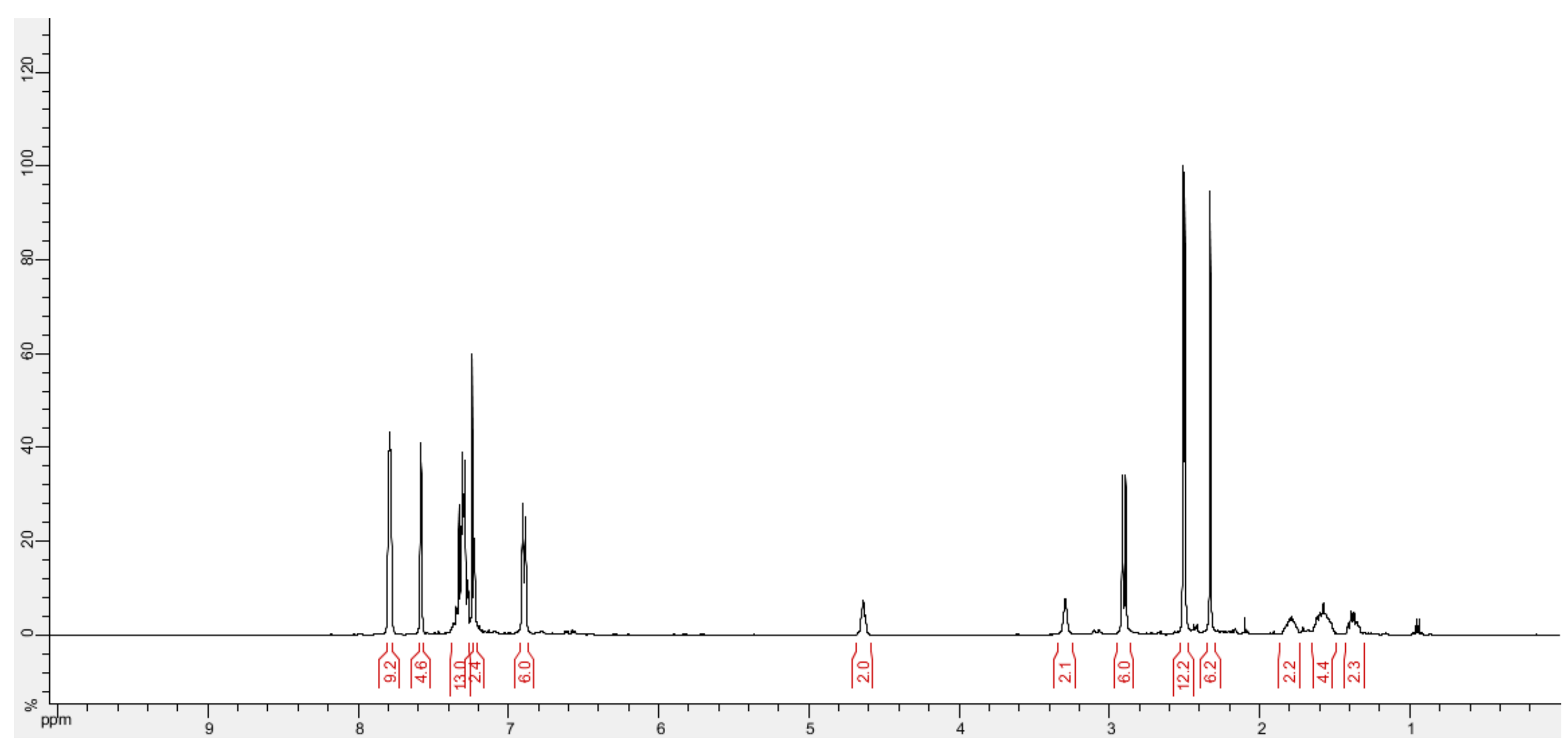




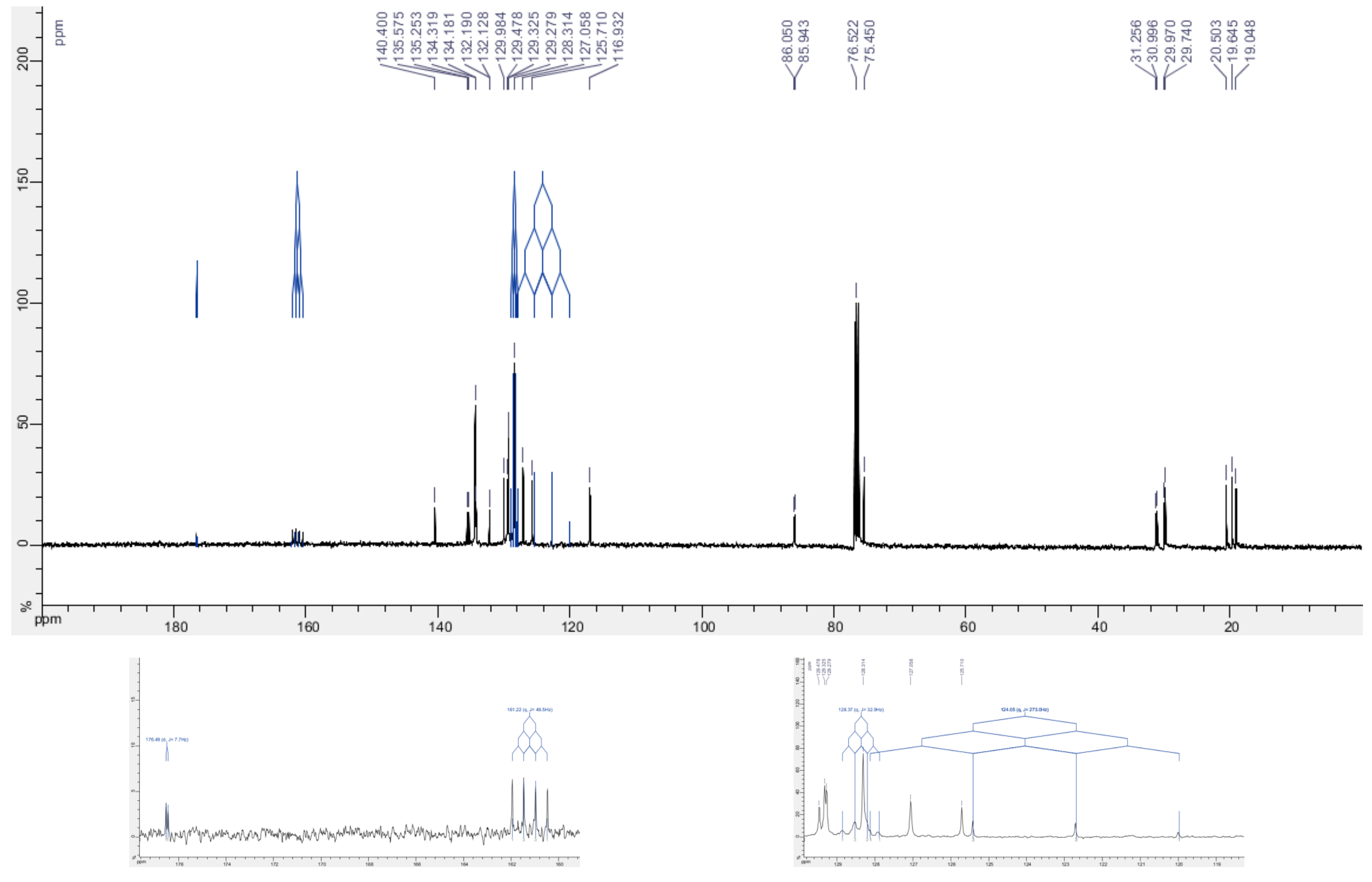


${ }^{19}$ F NMR

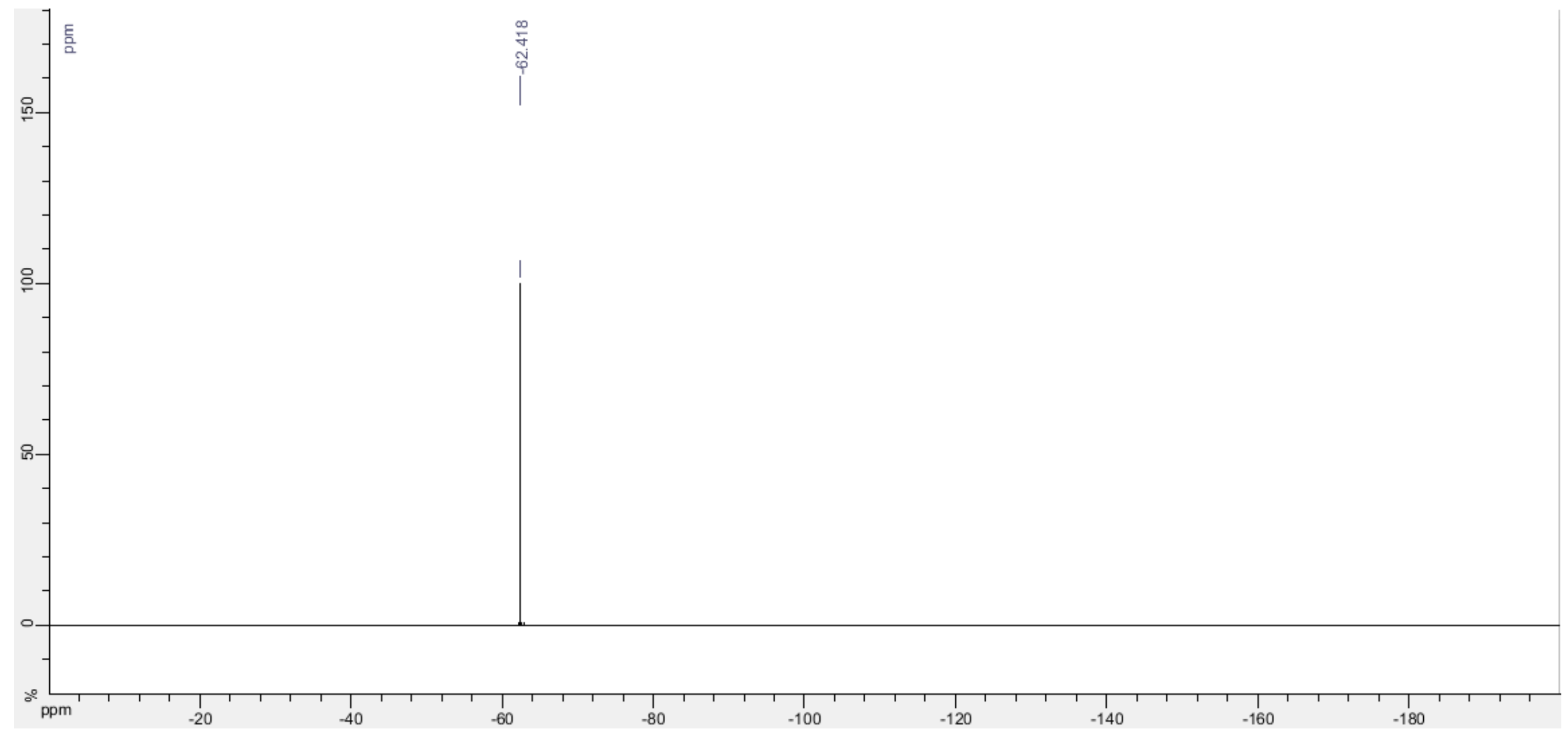


${ }^{31} \mathrm{P}$ NMR

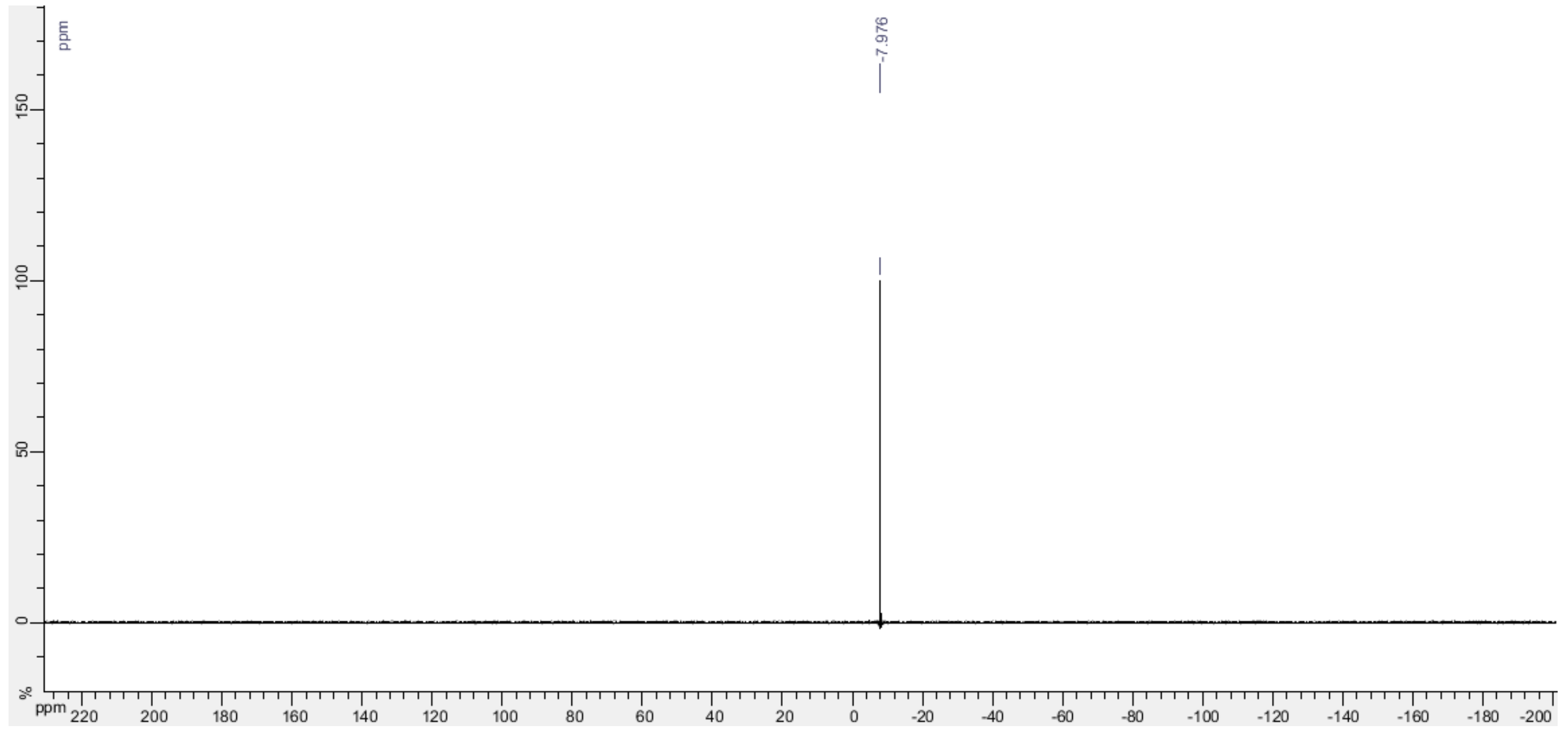




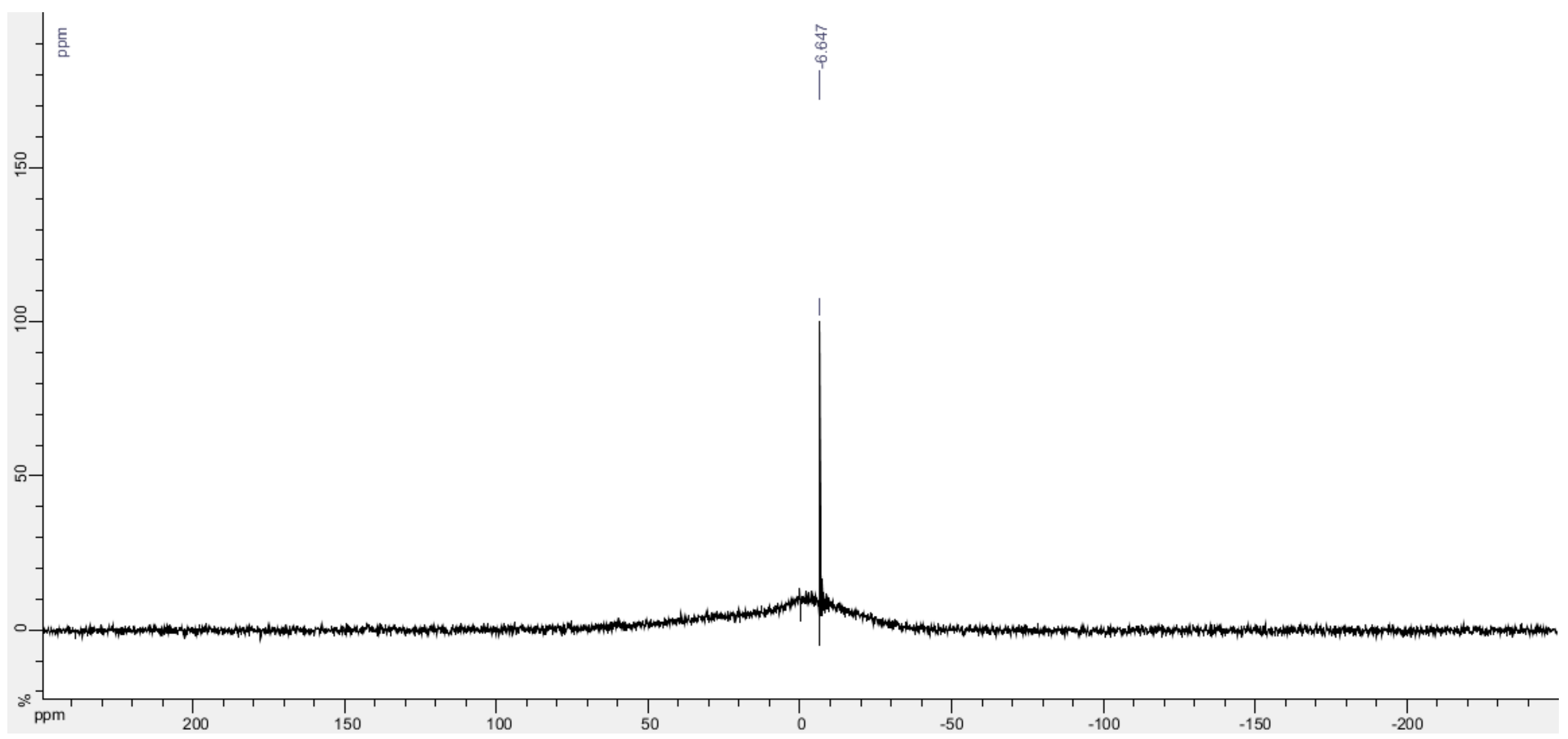


9.2. Example LC-MS and NMR data of unlabelled and labelled substrates (2 and [D]-2)

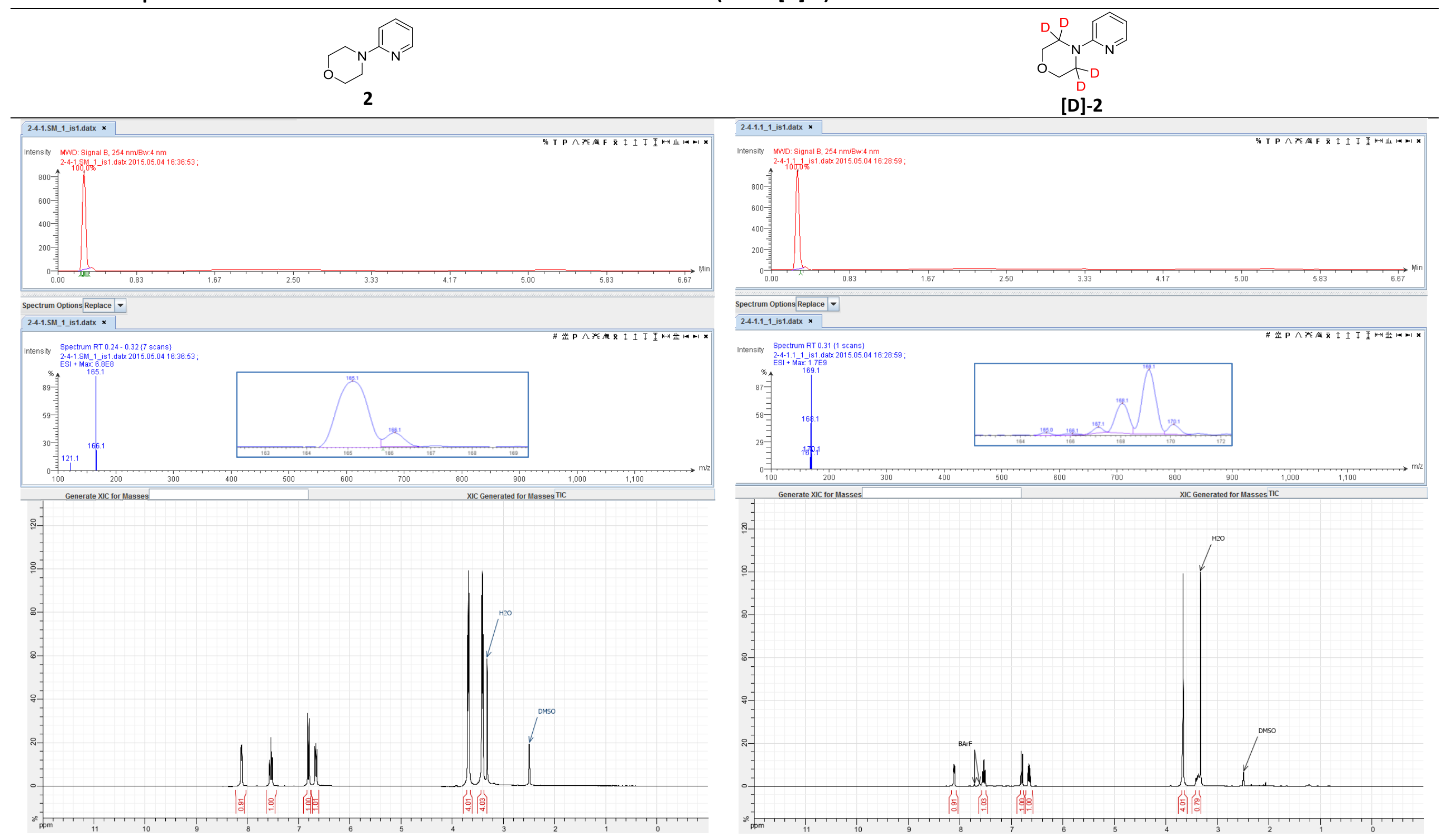




\section{References}

1. Kennedy, A. R.; Kerr, W. J.; Moir, R.; Reid, M. Anion Effects to Deliver Enhanced Iridium Catalysts for Hydrogen Isotope Exchange Processes. Org. Biomol. Chem. 2014, 12, 7927-7931.

2. Kerr, W. J.; Mudd, R. J.; Brown, J. A. Iridium(I) N-Heterocyclic Carbene (NHC)/Phosphine Catalysts for Mild and Chemoselective Hydrogenation Processes. Chem. Eur. J. 2016, 22, 4738-4742.

3. Wüstenberg, B.; Pfaltz, A. Homogeneous Hydrogenation of Tri- and Tetrasubstituted Olefins: Comparison of Iridium-Phospinooxazoline [Ir-PHOX] Complexes and Crabtree Catalysts with Hexafluorophosphate $\left(\mathrm{PF}_{6}\right)$ and Tetrakis[3,5-bis(trifluoromethyl)phenyl]borate (BArF) as Counterions. Adv. Synth. Catal. 2008, 350, 174-178.

4. Wagaw, S.; Buchwald, S. L. The Synthesis of Aminopyridines: A Method Employing Palladium-Catalyzed Carbon-Nitrogen Bond Formation. J. Org. Chem. 1996, 61, 7240-7241.

5. Boudet, N.; Dubbaka, S. R.; Knochel, P. Oxidative Amination of Cuprated Pyrimidine and Purine Derivatives. Org. Lett. 2008, 10, 1715-1718.

6. Li, G.; Jia, C.; Sun, K.; Lv, Y.; Zhao, F.; Zhou, K.; Wu, H. Copper(II)-Catalyzed Electrophilic Amination of Quinolone N-Oxides with O-Benzoyl Hydroxylamines. Org. Biomol. Chem. 2015, 13, 3207-3210.

7. Roiban, G.-D.; Mehler, G.; Reetz, M. T. Palladium-Catalysed Amination of Aryl- and Heteroaryl Halides Using tert-Butyl Tetraisopropylphosphorodiamidite as an Easily Accessible and Air-Stable Ligand. Eur. J. Org. Chem. 2014, 2014, 2070-2076.

8. Gulevskaya, A. V.; Maes, B. U. W.; Meyers, C.; Herrebout, W. A.; van der Veken, B. J. C-N Bond Formation by the Oxidative Alkylamination of Azines: Comparison of $\mathrm{AgPy}_{2} \mathrm{MnO}_{4}$ versus $\mathrm{KMnO}_{4}$ as Oxidant. Eur. J. Org. Chem. 2006, 2006, 5305-5314.

9. Masashiro, K.; William, H. N.; Naoki, T.; Hiroshi, B.; Yasuhiko, K.; Nobuhiro, I. Fused Quinoline Derivative and Use Thereof. WO2005105802 (A1), November 10, 2005.

10. Romanens, A.; Bélanger, G. Preparation of Conformationally Restricted $\beta^{2,2}$ - and $\beta^{2,2,3}$-Amino Esters and Derivatives Containing an All-Carbon Quaternary Center. Org. Lett. 2015, 17, 322-325.

11. Compound commercially available from Fluorochem.

12. Compound commercially available from Fluorochem.

13. Katamreddy, S. R.; Carpenter, A. J.; Ammala, C. E.; Boros, E. E.; Brashear, R. L.; Briscoe, C. P.; Bullard, S. R.; Caldwell, R. D.; Conlee, C. R.; Croom, D. K.; Hart, S. M.; Heyer, D. O.; Johnson, P. R.; Kashatus, J. A.; Minick, D. J.; Peckham, G. E.; Ross, S. A.; Roller, S. G.; Samano, V. A.; Sauls, H. R.; Tadepalli, S. M.; Thompson, J. B.; Xu, Y.; Way, J. M. Discovery of 6,7-Dihydro-5H-pyrrolo[2,3-a]pyrimidines as Orally Available G Protein-Coupled Receptor 119 Agonists. J. Med. Chem. 2012, 55, 10972-10994.

14. Takayama, T.; Shibata, T.; Shiozawa, F.; Kawabe, K.; Shimizu, Y.; Hamada, M.; Hiratate, A.; Takahashi, M.; Ushiyama, F.; Ol, T.; Shirasaki, Y.; Matsuda, D.; Koizumi, C.; Kato, S. Partially Saturated NitrogenContaining Heterocyclic Compound. EP2881384 (A1), June 10, 2015.

15. Johnson, P. S.; Ryckmans, T.; Bryans, J.; Beal, D. M.; Dack, K. N.; Feeder, N.; Harrison, A.; Lewis, M.; Mason, H. J.; Mills, J.; Newman, J.; Pasquinet, C.; Rawson, D. J.; Roberts, L. R.; Russell, R.; Spark, D.; Stobie, A.; Underwood, T. J.; Ward, R.; Wheeler, S. Discovery Of PF-184563, a Potent and Selective V1a Antagonist for the Treatment of Dysmenorrhoea. The Influence of Compound Flexibility on Microsomal Stability. Bioorg. Med. Chem. Lett. 2011, 21, 5684-5687.

16. The compound was obtained from a commercial supplier (Enamine).

17. Bouchon, A.; Diedrichs, N.; Hermann, A;. Lustig, K.; Meier, H.; Pernerstorfer, J.; Reissmuller, E.; de Vry, J.; Mogi, M.; Urbahns, K.; Yura, T.; Jishima, H.; Tajimi, M.; Yamamoto, N.; Yuasa, H.; Gupta, J.; Tsukimi, Y.; Hayashi, F. Tetrahydro-Naphthalene and Urea Derivatives. WO2005040119 (A1), May 6, 2005.

18. Brenner, E.; Schneider, R.; Fort, Y. Nickel-catalysed selective $\mathrm{N}$-arylation or $\mathrm{N}, \mathrm{N}^{\prime}$-diarylation of secondary diamines. Tetrahedron 2002, 58, 6913-6924.

19. Keenan, M.; Chaplin, J. H.; Alexander, P. W.; Abbot, M. J.; Best, W. M.; Khong, A.; Botero, A.; Perez, C.; Cornwall, S.; Thompson, R. A.; White, K. L.; Shackleford, D. M.; Koltun, M.; Chiu, F. C. K.; Morizzi, J.; Ryan, 
E.; Campbell, M.; von Geldern, T. W.; Scandale, I.; Chatelain, E.; Charman, S. A. Nickel-catalysed selective Narylation or N,N'-diarylation of secondary diamines. J. Med. Chem. 2013, 56, 10158-10170.

20. Zimmermann, H.; Bruckner, D.; Henninger, K.; Rosentreter, U.; Hendrox, M.; Keldenich, J.; Land, D.; Radke, M.; Palsen, D.; Kern, A. Heterocyclylamid-Substituierte Imidazole. WO2006089664 (A2), August 31, 2006.

21. Thurkauf, A. The synthesis of tritiated 2-phenyl-4-[4-(2-pyrimidyl)piperazinyl]methylimidazole $\left(\left[{ }^{3} \mathrm{H}\right]\right.$ NGD 94-1), a ligand selective for the dopamine $D_{4}$ receptor subtype. J. Labelled Compd. Radiopharm. 1997, 39, 123-128.

22. Verma, S. K.; Acharya, B. N.; Kaushik, M. P. Chemospecific and Ligand Free Cul Catalysed Heterogeneous N-Arylation of Amines with Diheteroaryl Halides at Room Temperature. Org. Biomol. Chem. 2011, 9, 1324-1327.

23. Compound commercially available from Apollo Scientific.

24. Coburn, C. A.; Maletic, M.; Soll, R.; Li, C.; Luo, Y.; Qi, Z. Sulfonamide Derivatives and Methods of Use Thereof for Improving the Pharmacokinetics of a Drug. WO2014000178 (A1), January 3, 2014.

25. Heng, R.; Koch, G.; Schlapbach, A.; Seiler, M. P. Pyrrole Derivatives Useful for the Treatment of Cytokine-Mediated Diseases. WO2008034600 (A1), March 27, 2008.

26. Compound commercially available from Fluorochem.

27. Ueno, H.; Yamamoto, T.; Takashita, R.; Yokohama, R.; Sugiura, T.; Kageyama, S.; Ando, A.; Eda, H.; Eviryanti, A.; Miyazawa, T.; Kirihara, A.; Tanabe, I.; Nakamura, T.; Noguchi, M.; Shuto, M.; Sugiki, M.; Dohi, M. Sulfonamide Derivative and Medicinal Use Thereof. US2015051395 (A1), February 19, 2015.

28. Compound commercially available from $\mathrm{TCl}$.

29. Wang, D.; Kuang, D.; Zhang, F.; Yang, C.; Zhu, X. Room-Temperature Copper-Catalyzed Arylation of Dimethylamine and Methylamine in Neat Water. Adv. Synth. Catal. 2015, 357, 714-718.

30. Gowrisankar, S.; Neumann, H.; Beller, M. A Convenient and Practical Synthesis of Anisoles and Deuterated Anisoles by Palladium-Catalyzed Coupling Reactions of Aryl Bromides and Chlorides. Chem. Eur. J. 2012, 18, 2498-2502.

31. Yuan, Y.; Zaidi, S. A.; Elbegdorj, O.; Aschenbach, L. C. K.; Li, G.; Stevens, D. L.; Scoggins, K. L.; Dewey, W. L.; Selley, D. E.; Zhang, Y. Design, Synthesis, and Biological Evaluation of 14-Heteroaromatic-Substituted Naltrexone Derivatives: Pharmacological Profile Switch from Mu Opioid Receptor Selectivity to Mu/Kappa Opioid Receptor Dual Selectivity. J. Med. Chem. 2013, 56, 9156-9169.

32. Shen, Z.-L.; Goh, K. K. K.; Wong, C. H. A.; Yang, Y.-S.; Lai, Y.-C.; Cheong, H.-L.; Loh, T.-P. Direct Synthesis of Ester-Containing Indium Homoenolate and its Application in Palladium-Catalyzed Cross-Coupling with Aryl Halide. Chem. Commun. 2011, 47, 4778-4780.

33. Kemperman, G. J. A Method for the Preparation of an Enantiomerically Pure Benzazepine. WO2008125577 (A1), October 23, 2008.

34. Migliaccio, G. P.; Byrn, S. R. Comparisons of Rotamer Populations of Nialamide, Azaperone, and Chloroquine in Solid State and in Solution. J. Pharm. Sci. 1981, 70, 284-287.

35. Martins, I. L.; Miranda, J. P.; Oliveira, N. G.; Fernandes, A. S.; Gonçalves, S.; Atunes, A. M. M. Synthesis and Biological Activity of 6-Selenocaffeine: Potential Modulator of Chemotherapeutic Drugs in Breast Cancer Cells. Molecules 2013, 18, 5251-5264. 